\title{
De arbeidsmarktpositie van schoolverlaters van het economisch en administratief (K)MBO : RUBS '91
}

Citation for published version (APA):

Lodder, B. J. H., Ramaekers, G. W. M., \& van der Velden, R. K. W. (1991). De arbeidsmarktpositie van schoolverlaters van het economisch en administratief (K)MBO : RUBS '91. Researchcentrum voor Onderwijs en Arbeidsmarkt, Faculteit der Economische Wetenschappen. ROA Reports No. 11 https://doi.org/10.26481/umarep.1991011

Document status and date:

Published: 01/01/1991

DOI:

10.26481/umarep.1991011

Document Version:

Publisher's PDF, also known as Version of record

\section{Please check the document version of this publication:}

- A submitted manuscript is the version of the article upon submission and before peer-review. There can be important differences between the submitted version and the official published version of record.

People interested in the research are advised to contact the author for the final version of the publication, or visit the DOI to the publisher's website.

- The final author version and the galley proof are versions of the publication after peer review.

- The final published version features the final layout of the paper including the volume, issue and page numbers.

Link to publication

\footnotetext{
General rights rights.

- You may freely distribute the URL identifying the publication in the public portal. please follow below link for the End User Agreement:

www.umlib.nl/taverne-license

Take down policy

If you believe that this document breaches copyright please contact us at:

repository@maastrichtuniversity.nl

providing details and we will investigate your claim.
}

Copyright and moral rights for the publications made accessible in the public portal are retained by the authors and/or other copyright owners and it is a condition of accessing publications that users recognise and abide by the legal requirements associated with these

- Users may download and print one copy of any publication from the public portal for the purpose of private study or research.

- You may not further distribute the material or use it for any profit-making activity or commercial gain

If the publication is distributed under the terms of Article $25 \mathrm{fa}$ of the Dutch Copyright Act, indicated by the "Taverne" license above, 
DE ARBEIDSMARKTPOSITIE VAN SCHOOLVERLATERS VAN HET ECONOMISCH EN ADMINISTRATIEF (K)MBO

-RUBS '91.

ROA-R-1991/11

B.J.H. Lodder

G.W.M. Ramaekers

R.K.W. van der Velden

RESEARCHCENTRUM VOOR ONDERWIJS EN ARBEIDSMARKT

Faculteit der Economische Wetenschappen

Rijksuniversiteit Limburg

Maastricht, december 1991 
CIP-GEGEVENS KONINKLIJKE BIBLIOTHEEK, DEN HAAG

Lodder, B.J.H.

De arbeidsmarktpositie van schoolverlaters van het economisch en administratief (K)MBO: RUBS ' 91 / B.J.H. Lodder, G.W.M. Ramaekers, R.K.W. van der Velden. - Maastricht; Researchcentrum voor Onderwijs en Arbeidsmarkt, Faculteit der Economische Wetenschappen, Rijksuniversiteit Limburg. - (Rapport /Researchcentrum voor Onderwijs en Arbeidsmarkt, ISSN 0922-8098; $1991 / 111$

Met lit. opg.

ISBN 90-5321-072-5 geb.

Trefw.: schoolverlaters ; EAO. 


\section{INHOUDSOPGAVE}

\section{bladzijde}

VERANTWOORDING

1. INLEIDING

2. HET RUBS-PROJECT 3

2.1. Opzet 3

2.2. Dekkingsgraad en respons 3

2.3. Opschonen van de data en herweging naar landelijke cijfers 5

3. PERSOONSKENMERKEN EN GENOTEN OPLEIDING 7

3.1. Inleiding 7

3.2. Opleidingskenmerken 7

3.2.1. Opleiding 7

3.2.2. Vooropleiding 9

3.3. Persoonskenmerken 10

4. BESTEMMING VAN DE SCHOOLVERLATERS

4.1. Inleiding 14

4.2. Bestemming van de schoolverlaters van het EAO, MDGO en MTO 17

4.3. Regionale verschillen in de bestemming van EAO-schoolverlaters 18

4.4. Verklaring van de verschillen in bestemming $\quad 19$

5. VERDER GEVOLGD ONDERWIJS

5.1. Inleiding 21

5.2. Voltijd-onderwijs 21

5.3. Aanvullende cursussen en trainingen 23

6. ARBEIDSMARKTINTREDE VAN DE SCHOOLVERLATERS 25

6.1. Zoekduur 25

6.2. Wijze van functieverwerving 26

7. DE POSITIE OP DE ARBEIDSMARKT VAN DE EAO-SCHOOLVERLATERS 28

7.1. Inleiding 28

7.2. Arbeidsparticipatie 28

7.3. Baanstabiliteit 29 
7.3.2. Conjunctuurgevoeligheid 30

7.4. Flexibiliteit

8. BEROEPSUITOEFENING VAN DE EAO-SCHOOLVERLATERS 34

8.1. Inleiding 34

8.2. Bedrijfssector en grootte van de werkorganisatie $\quad 34$

8.3. Beroep 37

8.4. Inkomen 41

8.5. Aansluiting van de functie op de opleiding 43

9. OORDEEL OVER DE OPLEIDING EN ZOEKGEDRAG 48

10. CONCLUSIES 56

$\begin{array}{ll}\text { LITERATUUR } & 60\end{array}$

BIJLAGE I : DEFINITIE VAN EXOGENEN IN DE MULTIVARIATE ANALYSES

BIJLAGE II : SCHATTINGSRESULTATEN 63

BIJLAGE III : ARBEIDSMARKTINDICATOREN

BIJLAGE IV : VRAGENLIJSTEN RUBS 1991 


\section{VERANTWOORDING}

Dit rapport doet verslag van de onderzoekresultaten met betrekking tot de schoolverlaters van het economisch en administratief onderwijs op middelbaar niveau op basis van gegevens die landelijk zijn verzameld in het kader van de RUBS-enquete 1991 (Registratie van de Uitstroom en de Bestemming van Schoolverlaters). De opdracht voor de RUBS-enquête in 1991 is afkomstig van het Ministerie van Onderwijs en Wetenschappen en het Centraal Bestuur voor de Arbeidsvoorziening. De uitvoering ervan is door het Contactcentrum voor Onderwijs en Arbeid Rijndelta uitbesteed aan het Servicebureau Schoolverlatersinformatie.

Het onderzoek is begeleid door een klankbordcommissie waarin de volgende personen zitting hadden:

- Mevr. J. van de Bandt (Verbond van Nederlandse Ondernemingen)

- Dhr. H. Claassen (Ministerie van Onderwijs en Wetenschappen)

- Mevr. M. Depondt (Contactcentrum voor Onderwijs en Arbeid Limburg)

- Dhr. J. Fokkema (Ministerie van Sociale Zaken en Werkgelegenheid)

- Dhr. J. Geurts (Procescoördinatie Sectorvorming in het Middelbaar Beroepsonderwijs)

- Mevr. A. Hesselman (Economische Sector Groep)

- Dhr. R. Roelofse (Christelijk Nederlands Vakverbond)

- Dhr. R. van der Velden (Researchcentrum voor Onderwijs en Arbeidsmarkt)

- Mevr. D. Versloot (Contactcentrum voor Onderwijs en Arbeid Rijndelta)

- Dhr. R. de Wit (Landelijk Dienstverlenend Centrum voor Studie- en Beroepskeuzevoorlichting) Het secretariaat van de Klankbordcommissie was ondergebracht bij het Servicebureau Schoolverlatersinformatie.

Op verzoek van het Servicebureau Schoolverlatersinformatie heeft het Researchcentrum voor Onderwijs en Arbeidsmarkt de enquêtegegevens geanalyseerd en over de resultaten hiervan in het onderhavige rapport verslag gedaan. De analyse en rapportage zijn verricht door J. le, drs. B.J.H. Lodder, drs. G.W.M. Ramaekers en dr. R.K.W. van der Velden (projectleider).

Wij danken de heren $H$. Rutjes van het Servicebureau Schoolverlatersinformatie en $H$. Berendsen van het Researchcentrum voor Onderwijs en Arbeidsmarkt voor hun commentaar op de concept-versie van het rapport. Uiteraard was dit rapport nooit tot stand gekomen zonder de bereidheid van scholen en de schoolverlaters zelf om aan de enquête mee te werken. 
( 


\section{INLEIDING}

Het RUBS-project (Registratie van de Uitstroom en de Bestemming van Schoolverlaters) betreft een jaarlijkse, grootschalige enquete onder zowel ongediplomeerde als gediplomeerde schoolverlaters van het algemeen voortgezet onderwijs en het lager en middelbaar beroepsonderwijs voor het achterhalen van de 'eerste bestemming'. Hierdoor wordt een actueel beeld verkregen van de positie op de arbeidsmarkt van de schoolverlaters en de aansluiting tussen onderwijs en arbeidsmarkt, verbijzonderd naar opleidingstype en vakrichting.

De in RUBS '91 gebruikte vragenlijsten, die in bijlage IV zijn opgenomen, gaan achtereenvolgens in op:

- enkele persoonsgerelateerde kenmerken en de woonplaats;

- de in het schooljaar 1989/'90 gevolgde opleiding en de vooropleiding;

- de bezigheid die men thans verricht;

- de full-time dagopleiding die men thans volgt (indien van toepassing):

- de opleiding in het leerlingwezen of de in-service opleiding in de verpleging of verzorging die men thans volgt (indien van toepassing);

- het huidige werk en beroep (indien van toepassing);

- het zoeken naar (ander) werk;

- het oordeel over de in het schooljaar 1989/"90 gevolgde opleiding.

Voorafgaand aan de presentatie van de onderzoekresultaten wanrdt in hamtant.t. $n$ A... 
$-2-$

alleen schoolverlaters van het EAO betreft, wordt gesproken over 'EAO-schoolverlaters'. Waar relevant worden in de toelichting op de kruistabellen ook steeds de resultaten van de desbetreffende multivariate analyse besproken. De operationalisering van de in de multivariate analyses gebruikte variabelen is weergegeven in bijlage I. De schattingsresultaten van deze analyses zijn opgenomen in bijlage II. Bij alle schattingen (behoudens van het inkomen) zijn de parameters van de verklarende variabelen, met uitzondering van de gevolgde opleiding, met behulp van afzonderlijke Chi-kwadraat toetsen op hun sianificantie onderzontht Me cinnifinsntis was to 


\section{HET RUBS-PROJECT}

\subsection{Opzet}

RUBS is een jaarlijkse, schriftelijke enquête die wordt gehouden onder gediplomeerde en nietgediplomeerde schoolverlaters van het algemeen voortgezet onderwijs en het lager en middelbaar beroepsonderwijs. De vragenlijsten zijn voor alle schooltypen vrijwel gelijk. De kern van RUBS wordt gevormd door een schriftelijke berraning

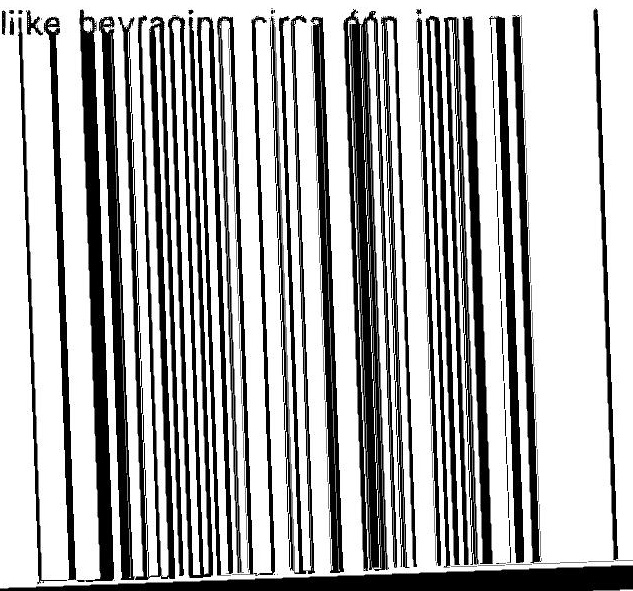


Tabel 1A. Dekkingsgraad RUBS '91

\begin{tabular}{lccc}
\hline & Populatie & $\begin{array}{c}\text { Deeiname } \\
\text { (uitgezette vragenlijsten) } \\
N\end{array}$ & $\begin{array}{c}\text { Dekkingsgraad } \\
\text { N }\end{array}$ \\
\hline aantal scholen & & & \\
- MEAO & $73 *$ & 39 & 53 \\
- MMO & $51 *$ & 16 & 31 \\
- KMBO-EAO & $51 *$ & 17 & 33 \\
aantal gediplomeerden & & & \\
- MEAO & & 7178 & 56 \\
- MMO & $12790 *$ & 2049 & 26 \\
- KMBO-EAO & $7739 *$ & 1038 & 20 \\
\hline
\end{tabular}

Bron: * Integrale Leerling Telling 1991 (ILT), Ministerie van Onderwijs en Wetenschappen

- Statistiek van het middelbaar beroepsonderwijs 1989/'90. Centraal Bureau voor de Statistiek. Aantal scholen betreft het totaal aantal KMBO-scholen. Aantal leerlingen betreft het totaal aantal leerlingen in het $2 e$ leerjaar van detailhandel en administratie

In tabel 1B wordt een overzicht gegeven van de respons onder de aangeschreven EAOschoolverlaters op de RUBS-enquête. In de tabel komt naar voren dat $61 \%$ van de aangeschreven respondenten heeft meegedaan aan de enquête. Verschillen in respons tussen vakrichtingen zijn klein. Zoals te verwachten viel, is de respons onder ongediplomeerden lager dan de respons onder gediplomeerden.

Om na te gaan of degenen die niet hebben meegewerkt aan het onderzoek wellicht een specifieke groep vormen wat betreft de arbeidsmarktpositie, is op beperkte schaal een nonrespons onderzoek uitgevoerd. In totaal zijn 135 schoolverlaters afkomstig uit het EAO in het non-respons onderzoek betrokken. Met behulp van een telefonische enquête is nagegaan wat hun bestemming was op de arbeidsmarkt. Van de 135 non-respondenten hebben $101 \quad(=75 \%$ ) hun medewerking aan het telefonisch onderzoek verleend. In de analyse is bekeken in hoeverre er verschillen zijn in de bestemming tussen deze groep en de respondenten van het EAO. Het resultaat van deze analyse wordt weergegeven in tabel $1 \mathrm{C}$. Er blijken zich geen significante verschillen in bestemming voor te doen. Het enige verschil is dat de groep non-respondenten vaker een 'overige' bestemming heeft (met name betreft dit militaire dienst). Dit vormt tevens een gedeeltelijke verklaring van de non-respons: de desbetreffende personen waren vaak onbereikbaar. Dit betekent dat de hierna te presenteren gegevens representatief geacht mogen worden voor de totale populatie van schoolverlaters uit het EAO. 
$-5-$

Tabel 1B. Respons van de EAO-schoolverlaters op de RUBS-enquete

\begin{tabular}{|c|c|c|}
\hline Opleiding & $\begin{array}{c}\text { Uitgezet } \\
N\end{array}$ & $\begin{array}{c}\text { Respons } \\
\%\end{array}$ \\
\hline \multicolumn{3}{|l|}{ Gediplomeerden } \\
\hline \multicolumn{3}{|l|}{ KMBO } \\
\hline Detail & 319 & 62 \\
\hline Administratie & 719 & 62 \\
\hline \multicolumn{3}{|l|}{ MMO } \\
\hline Branche-differentiatie & 473 & 61 \\
\hline Commercieel & 1046 & 64 \\
\hline Overig & 530 & 74 \\
\hline \multicolumn{3}{|l|}{ MEAO } \\
\hline Bedrijfsadministratie & 2556 & 71 \\
\hline Commercieel & 1429 & 67 \\
\hline Bestuurlijk & 210 & 64 \\
\hline Secretarieel & 1122 & 70 \\
\hline Vrije Richting & 581 & 65 \\
\hline Nieuwe Richting & 239 & 62 \\
\hline Onbekend & 1041 & 69 \\
\hline Totaal gediplomeerden & 10265 & 68 \\
\hline Ongediplomeerden & 4734 & 47 \\
\hline Totaal & 14999 & 61 \\
\hline
\end{tabular}

Tabel 1C. Verdeling van bestemming binnen de respons groep en de non-respons groep

\begin{tabular}{|c|c|c|}
\hline Bestemming & $\begin{array}{l}\text { Respons groep } \\
\%\end{array}$ & $\begin{array}{c}\text { Non-respons groep } \\
\%\end{array}$ \\
\hline Betaalde baan (incl. LLW"/in-service) & 51 & 46 \\
\hline Werkloos & 2 & 1 \\
\hline Dagopleiding & 34 & 33 \\
\hline Overig & 13 & 20 \\
\hline Totaal $N(=100 \%)$ & 9182 & 101 \\
\hline (chi-kwadraat $=7.2$, d.f. $=3, p<0.05$ & & \\
\hline
\end{tabular}

* LLW = Leerlingwezen

\subsection{Herweging naar landelijke cijfers}

Het bestand van de gediplomeerden van het MEAO en het MDGO kon worden herwogen naar landelijke cijfers. Aangezien een groot aantal MEAO-schoolverlaters geen specificatie van de 
door hun gevolgde vakrichting heeft opgegeven (bij de gediplomeerden was dit $18 \%$ ), is het niet mogelijk geweest het MEAO-bestand te wegen naar vakrichting. Het MEAO-bestand is derhalve alleen naar provincie herwogen. Daarbij zijn de provincies Groningen, Friesland en Drenthe samengenomen. In de steekproef waren immers geen MEAO-scholen uit Friesland betrokken. Het was daarom onmogelijk om weegfactoren voor deze provincie op te stellen.

Bij het MDGO is zowel naar vakrichting als naar regio herwogen. Aangezien in de steekproef niet elke vakrichting van het MDGO in iedere provincie vertegenwoordigd is, is er voor gekozen om met betrekking tot de herweging bepaalde provincies samen te nemen. Door hierbij de provincies in de randstad (Utrecht, Noord-en Zuid-Holland) samen te nemen en de overige provincies eveneens samen te nemen, konden de wegingsfactoren binnen redelijke grenzen blijven.

Aangezien voor een groot aantal provincies respondenten van het KMBO en het MTO in de steekproef ontbreken, is het niet mogelijk de bestanden van het MTO en het KMBO te herwegen naar landelijke cijfers. Het MMO-bestand kwam pas in een later stadium beschikbaar, zodat dit bestand niet meer herwogen kon worden.

Tabel 2. Herwogen bestand van MEAO-schoolverlaters naar regio, vakrichting en diplomabezit

\begin{tabular}{|c|c|c|c|c|c|c|c|c|c|c|}
\hline \multirow[t]{2}{*}{ Opleiding } & \multicolumn{10}{|c|}{ Regio's } \\
\hline & $\underset{\%}{\mathrm{Gr} .+\mathrm{Fr} .+\mathrm{Dr} .}$ & $\begin{array}{r}\text { Ov. } \\
\%\end{array}$ & $\begin{array}{r}\text { Gel. } \\
\%\end{array}$ & $\begin{array}{l}\text { Ut. } \\
\%\end{array}$ & $\begin{array}{r}\mathrm{N}-\mathrm{H} \\
\%\end{array}$ & $\begin{array}{r}\mathrm{Z}-\mathrm{H} \\
\%\end{array}$ & $\begin{array}{r}\text { Zeel. } \\
\%\end{array}$ & $\begin{array}{l}\mathrm{Br} \\
\%\end{array}$ & $\underset{\%}{\operatorname{Lim} .}$ & $\begin{array}{l}\mathrm{Fl} . \\
\%\end{array}$ \\
\hline \multicolumn{11}{|l|}{ MEAO } \\
\hline \multicolumn{11}{|l|}{ I Gediplomeerden } \\
\hline Bedrijfsadministratie & 15 & 42 & 40 & 25 & 27 & 41 & 29 & - & 26 & 25 \\
\hline Commercieel & 7 & 21 & 18 & 15 & 16 & 17 & 23 & - & 13 & 10 \\
\hline Bestuurlijk & 2 & 6 & 2 & 2 & 3 & 3 & 2 & - & 0 & 3 \\
\hline Secretarieel & 8 & 10 & 16 & 12 & 9 & 17 & 10 & - & 14 & 12 \\
\hline Vrije richting & 2 & 10 & 6 & 3 & 9 & 11 & 11 & - & 3 & 13 \\
\hline Nieuwe richting & - & - & 2 & 3 & - & - & - & - & 8 & - \\
\hline Onbekend & 35 & - & - & 1 & 9 & - & - & 89 & 3 & - \\
\hline II Ongediplomeerden & 30 & 11 & 16 & 39 & 27 & 10 & 25 & 11 & 33 & 37 \\
\hline Totaal MEAO $(N=100 \%)$ & 789 & 648 & 668 & 538 & 741 & 1114 & 138 & 895 & 610 & 164 \\
\hline
\end{tabular}




\section{PERSOONSKENMERKEN EN GENOTEN OPLEIDING}

\subsection{Inleiding}

De aan de EAO-school gevolgde vakrichting alsmede het resultaat waarmee men deze opleiding heeft verlaten, vormt de eerste invalshoek van waaruit de arbeidsmarktbestemming inzichtelijk kan worden gemaakt. De verklaring van eventuele verschillen in arbeidsmarktbestemming die zich beperkt tot het aspect vakrichting en opleidingsresultaat is onvolledig, omdat de mate van succes op de arbeidsmarkt ook kan afhangen van extra kwalificaties in de vorm van een voltooide vooropleiding en een aantal individuele achtergrondkenmerken van de schoolverlaters.

In dit hoofdstuk worden de onderzochte EAO-schoolverlaters achtereenvolgens beschreven aan de hand van een aantal achtergrondkenmerken. Het gaat hierbij om een drietal persoonsgerelateerde kenmerken en een aantal kenmerken van de EAQ-opleiding en Yan fe Yonrnn|fiding

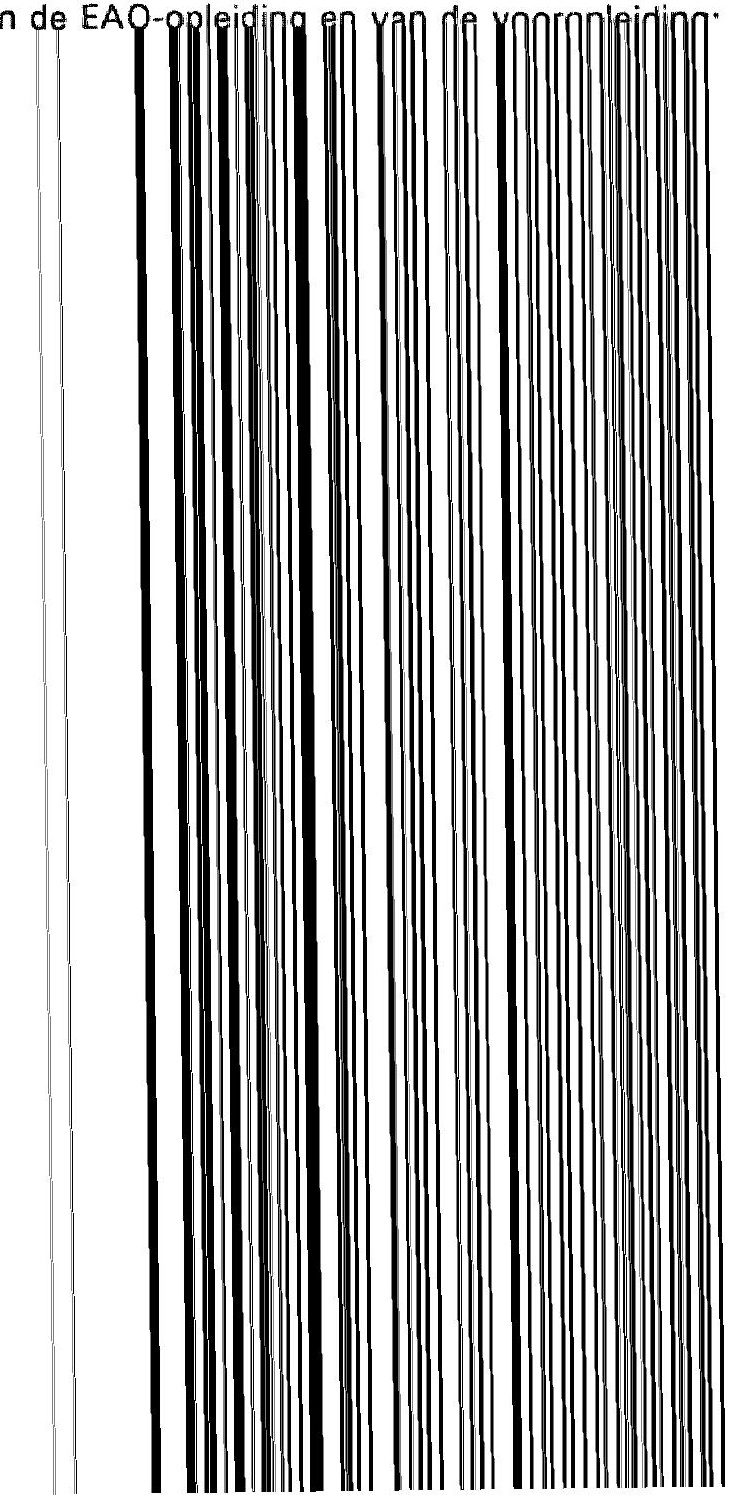




\section{PERSOONSKENMERKEN EN GENOTEN OPLEIDING}

\subsection{Inleiding}

De aan de EAO-school gevolgde vakrichting alsmede het resultaat waarmee men deze opleiding heeft verlaten, vormt de eerste invalshoek van waaruit de arbeidsmarktbestemming inzichtelijk kan worden gemaakt. De verklaring van eventuele verschillen in arbeidsmarktbestemming die zich beperkt tot het aspect vakrichting en opleidingsresultaat is onvolledig, omdat de mate van succes op de arbeidsmarkt ook kan afhangen van extra kwalificaties in de vorm van een voltooide vooropleiding en een aantal individuele achtergrondkenmerken van de schoolverlaters.

In dit hoofdstuk worden de onderzochte EAO-schoolverlaters achtereenvolgens beschreven aan de hand van een aantal achtergrondkenmerken. Het gaat hierbij om een drietal persoonsgerelateerde kenmerken en een aantal kenmerken van de EAQ-opleiding en Yan fe Yonrnn|fiding

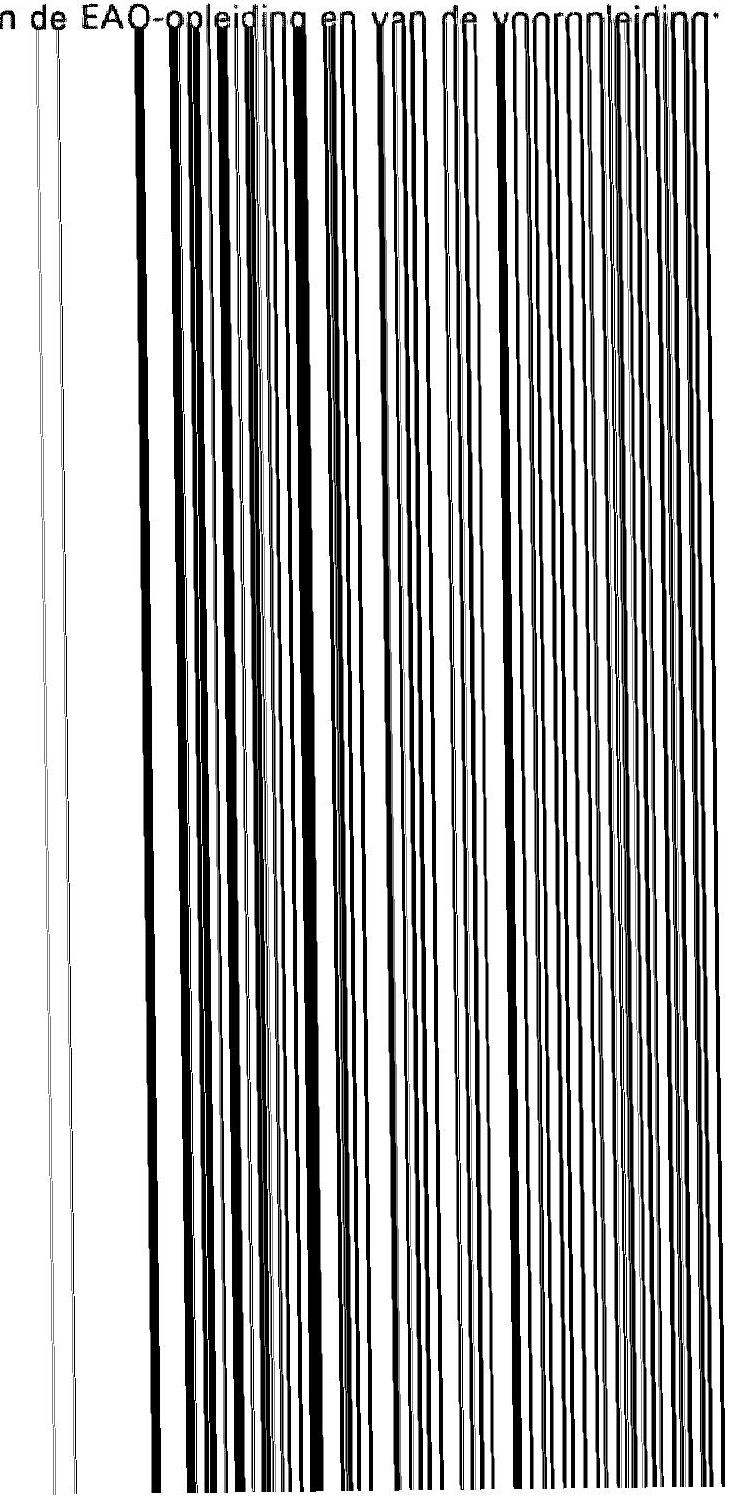




\section{PERSOONSKENMERKEN EN GENOTEN OPLEIDING}

\subsection{Inleiding}

De aan de EAO-school gevolgde vakrichting alsmede het resultaat waarmee men deze opleiding heeft verlaten, vormt de eerste invalshoek van waaruit de arbeidsmarktbestemming inzichtelijk kan worden gemaakt. De verklaring van eventuele verschillen in arbeidsmarktbestemming die zich beperkt tot het aspect vakrichting en opleidingsresultaat is onvolledig, omdat de mate van succes op de arbeidsmarkt ook kan afhangen van extra kwalificaties in de vorm van een voltooide vooropleiding en een aantal individuele achtergrondkenmerken van de schoolverlaters.

In dit hoofdstuk worden de onderzochte EAO-schoolverlaters achtereenvolgens beschreven aan de hand van een aantal achtergrondkenmerken. Het gaat hierbij om een drietal persoonsgerelateerde kenmerken en een aantal kenmerken van de EAQ-opleiding en Yan fe Yonrnn|fiding

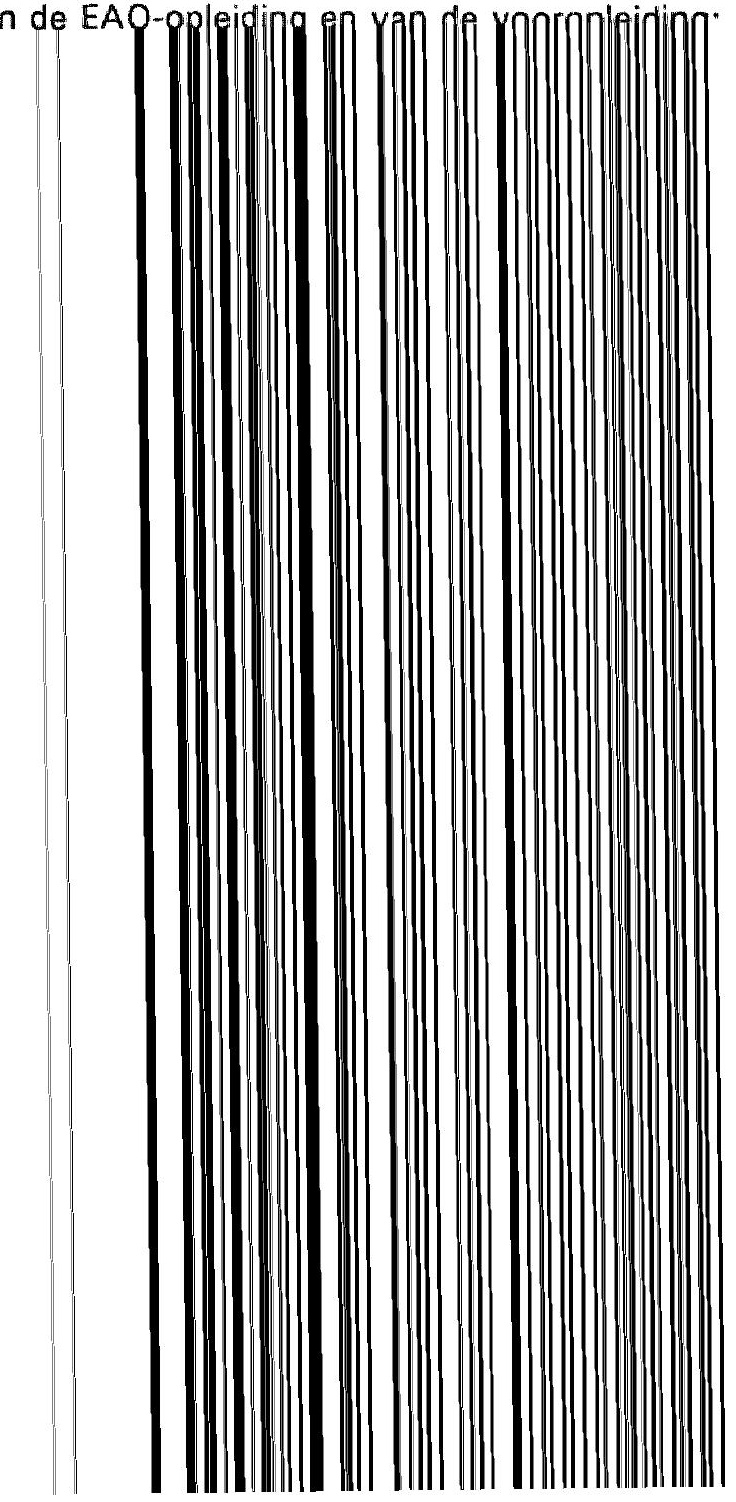




\section{PERSOONSKENMERKEN EN GENOTEN OPLEIDING}

\subsection{Inleiding}

De aan de EAO-school gevolgde vakrichting alsmede het resultaat waarmee men deze opleiding heeft verlaten, vormt de eerste invalshoek van waaruit de arbeidsmarktbestemming inzichtelijk kan worden gemaakt. De verklaring van eventuele verschillen in arbeidsmarktbestemming die zich beperkt tot het aspect vakrichting en opleidingsresultaat is onvolledig, omdat de mate van succes op de arbeidsmarkt ook kan afhangen van extra kwalificaties in de vorm van een voltooide vooropleiding en een aantal individuele achtergrondkenmerken van de schoolverlaters.

In dit hoofdstuk worden de onderzochte EAO-schoolverlaters achtereenvolgens beschreven aan de hand van een aantal achtergrondkenmerken. Het gaat hierbij om een drietal persoonsgerelateerde kenmerken en een aantal kenmerken van de EAQ-opleiding en Yan fe Yonrnn|fiding

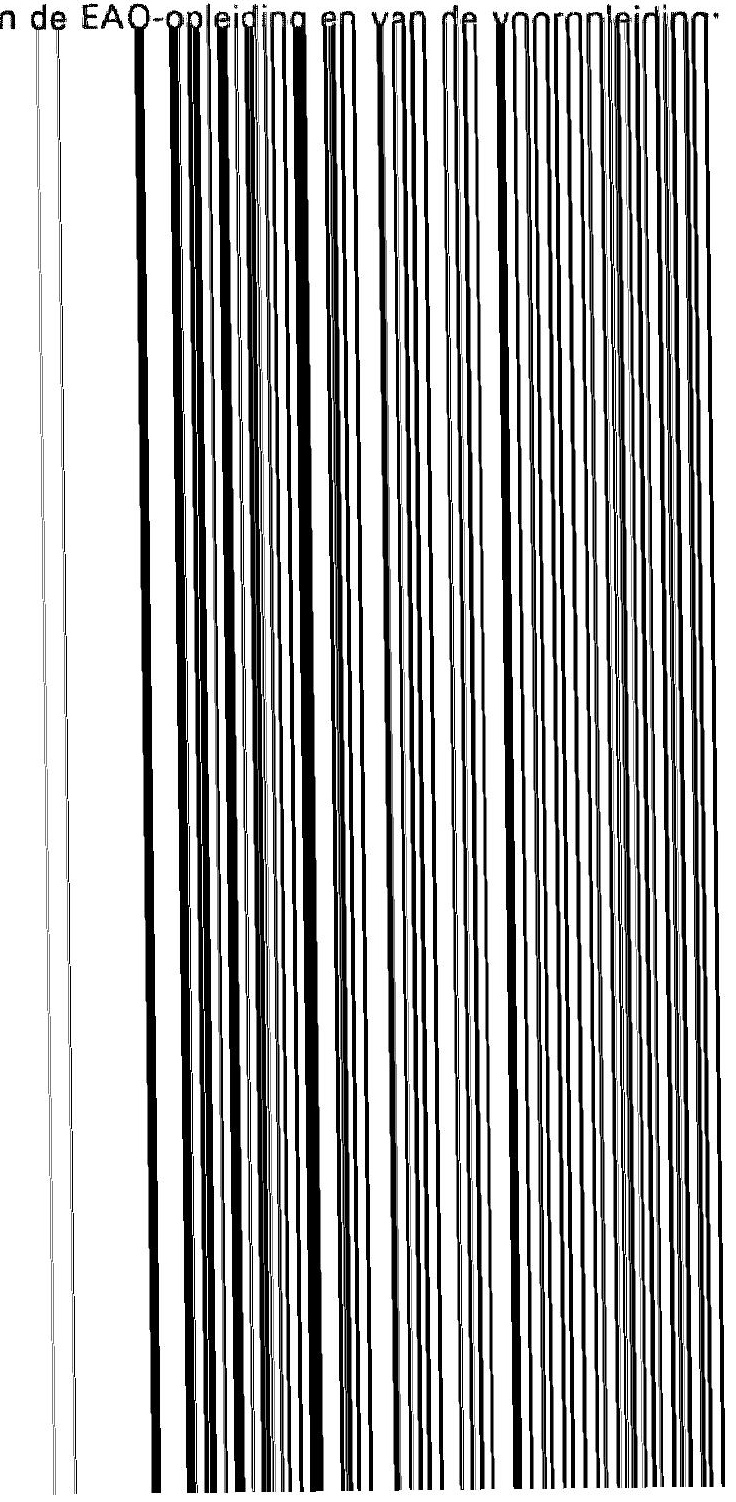




\section{PERSOONSKENMERKEN EN GENOTEN OPLEIDING}

\subsection{Inleiding}

De aan de EAO-school gevolgde vakrichting alsmede het resultaat waarmee men deze opleiding heeft verlaten, vormt de eerste invalshoek van waaruit de arbeidsmarktbestemming inzichtelijk kan worden gemaakt. De verklaring van eventuele verschillen in arbeidsmarktbestemming die zich beperkt tot het aspect vakrichting en opleidingsresultaat is onvolledig, omdat de mate van succes op de arbeidsmarkt ook kan afhangen van extra kwalificaties in de vorm van een voltooide vooropleiding en een aantal individuele achtergrondkenmerken van de schoolverlaters.

In dit hoofdstuk worden de onderzochte EAO-schoolverlaters achtereenvolgens beschreven aan de hand van een aantal achtergrondkenmerken. Het gaat hierbij om een drietal persoonsgerelateerde kenmerken en een aantal kenmerken van de EAQ-opleiding en Yan fe Yonrnn|fiding

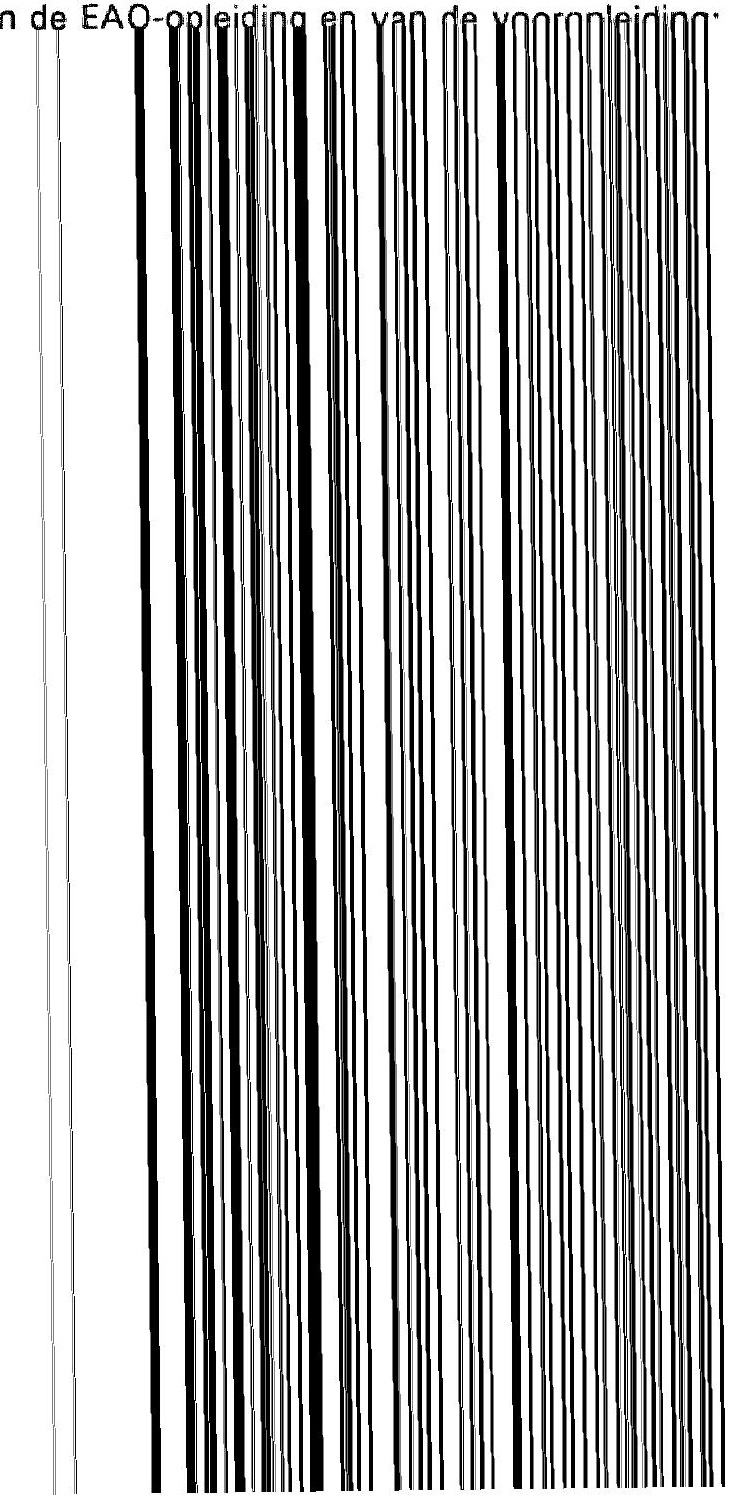




\section{PERSOONSKENMERKEN EN GENOTEN OPLEIDING}

\subsection{Inleiding}

De aan de EAO-school gevolgde vakrichting alsmede het resultaat waarmee men deze opleiding heeft verlaten, vormt de eerste invalshoek van waaruit de arbeidsmarktbestemming inzichtelijk kan worden gemaakt. De verklaring van eventuele verschillen in arbeidsmarktbestemming die zich beperkt tot het aspect vakrichting en opleidingsresultaat is onvolledig, omdat de mate van succes op de arbeidsmarkt ook kan afhangen van extra kwalificaties in de vorm van een voltooide vooropleiding en een aantal individuele achtergrondkenmerken van de schoolverlaters.

In dit hoofdstuk worden de onderzochte EAO-schoolverlaters achtereenvolgens beschreven aan de hand van een aantal achtergrondkenmerken. Het gaat hierbij om een drietal persoonsgerelateerde kenmerken en een aantal kenmerken van de EAQ-opleiding en Yan fe Yonrnn|fiding

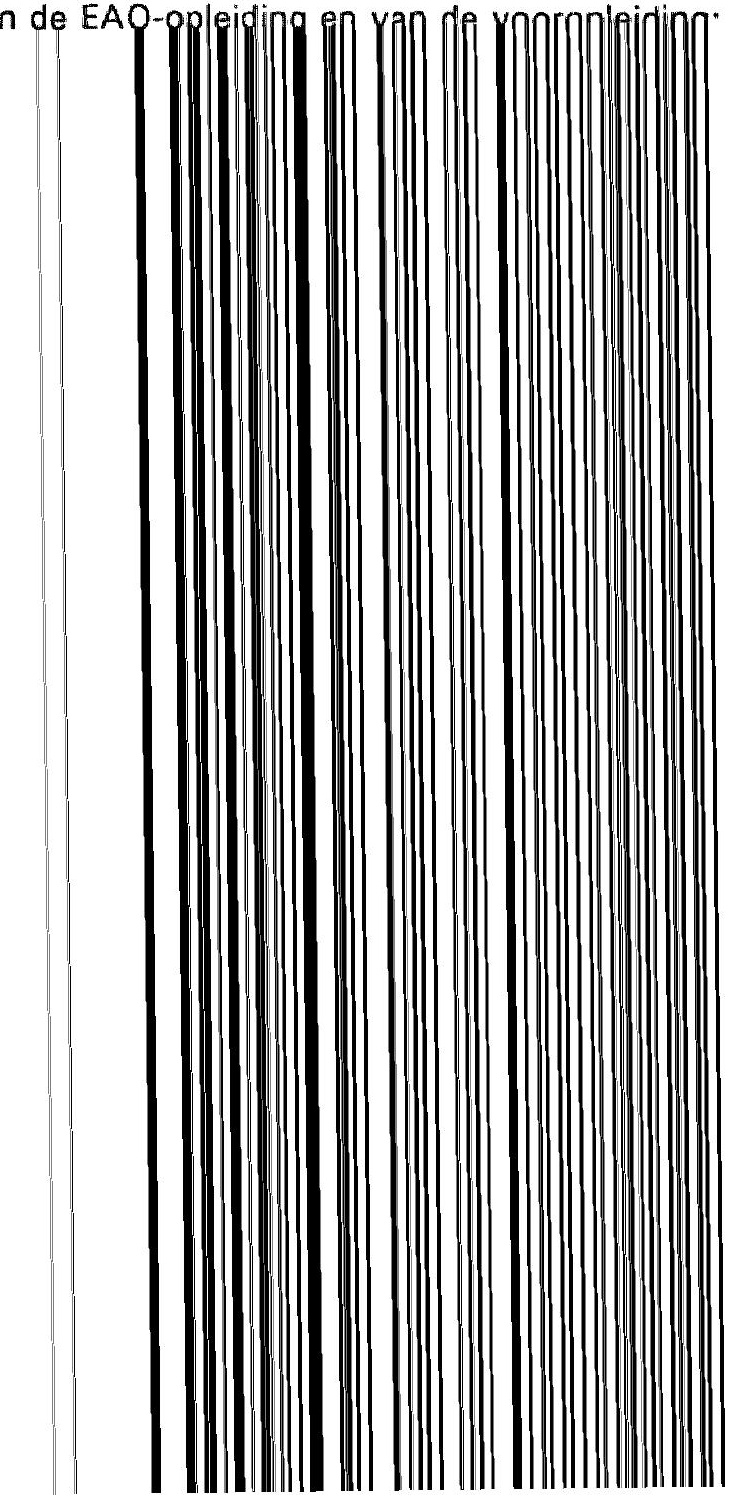




\section{PERSOONSKENMERKEN EN GENOTEN OPLEIDING}

\subsection{Inleiding}

De aan de EAO-school gevolgde vakrichting alsmede het resultaat waarmee men deze opleiding heeft verlaten, vormt de eerste invalshoek van waaruit de arbeidsmarktbestemming inzichtelijk kan worden gemaakt. De verklaring van eventuele verschillen in arbeidsmarktbestemming die zich beperkt tot het aspect vakrichting en opleidingsresultaat is onvolledig, omdat de mate van succes op de arbeidsmarkt ook kan afhangen van extra kwalificaties in de vorm van een voltooide vooropleiding en een aantal individuele achtergrondkenmerken van de schoolverlaters.

In dit hoofdstuk worden de onderzochte EAO-schoolverlaters achtereenvolgens beschreven aan de hand van een aantal achtergrondkenmerken. Het gaat hierbij om een drietal persoonsgerelateerde kenmerken en een aantal kenmerken van de EAQ-opleiding en Yan fe Yonrnn|fiding

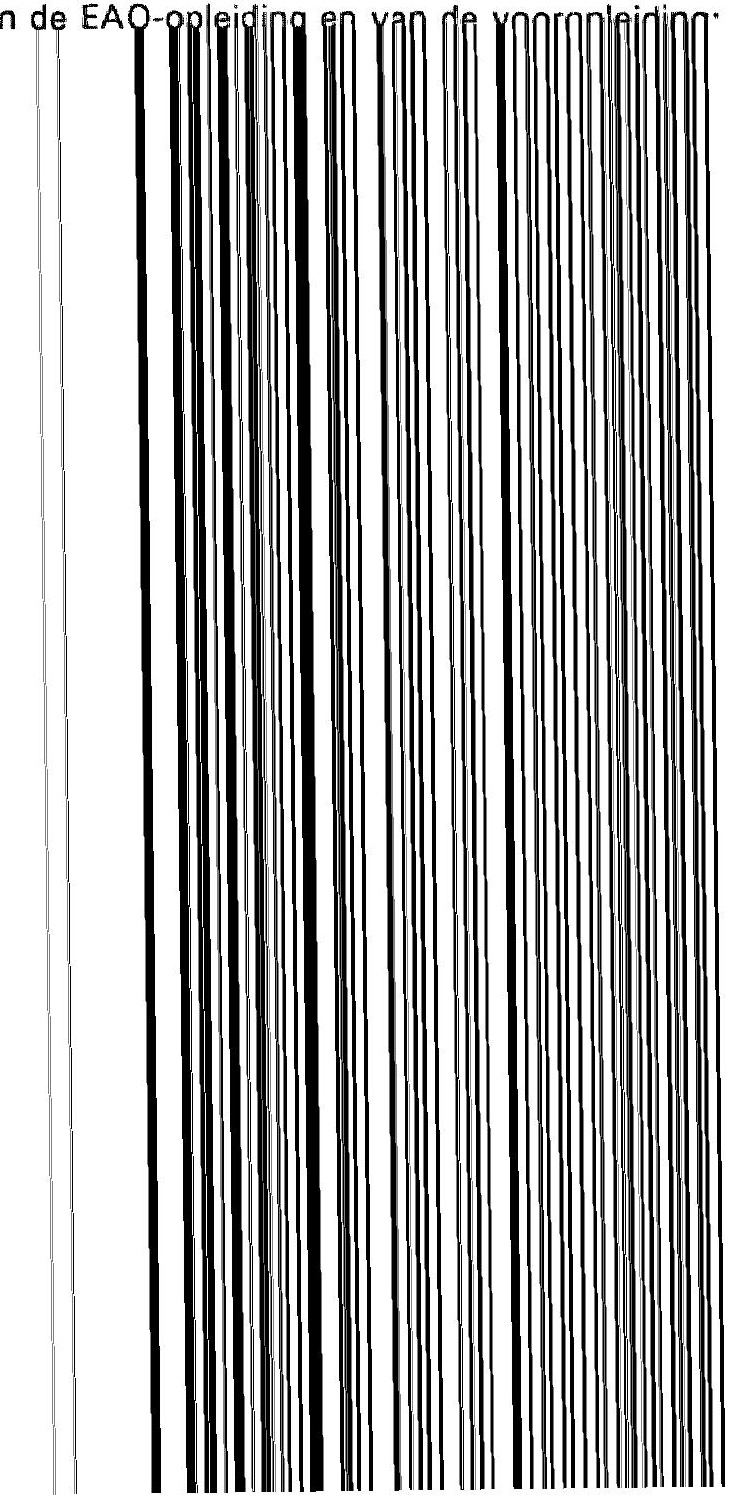




\section{PERSOONSKENMERKEN EN GENOTEN OPLEIDING}

\subsection{Inleiding}

De aan de EAO-school gevolgde vakrichting alsmede het resultaat waarmee men deze opleiding heeft verlaten, vormt de eerste invalshoek van waaruit de arbeidsmarktbestemming inzichtelijk kan worden gemaakt. De verklaring van eventuele verschillen in arbeidsmarktbestemming die zich beperkt tot het aspect vakrichting en opleidingsresultaat is onvolledig, omdat de mate van succes op de arbeidsmarkt ook kan afhangen van extra kwalificaties in de vorm van een voltooide vooropleiding en een aantal individuele achtergrondkenmerken van de schoolverlaters.

In dit hoofdstuk worden de onderzochte EAO-schoolverlaters achtereenvolgens beschreven aan de hand van een aantal achtergrondkenmerken. Het gaat hierbij om een drietal persoonsgerelateerde kenmerken en een aantal kenmerken van de EAQ-opleiding en Yan fe Yonrnn|fiding

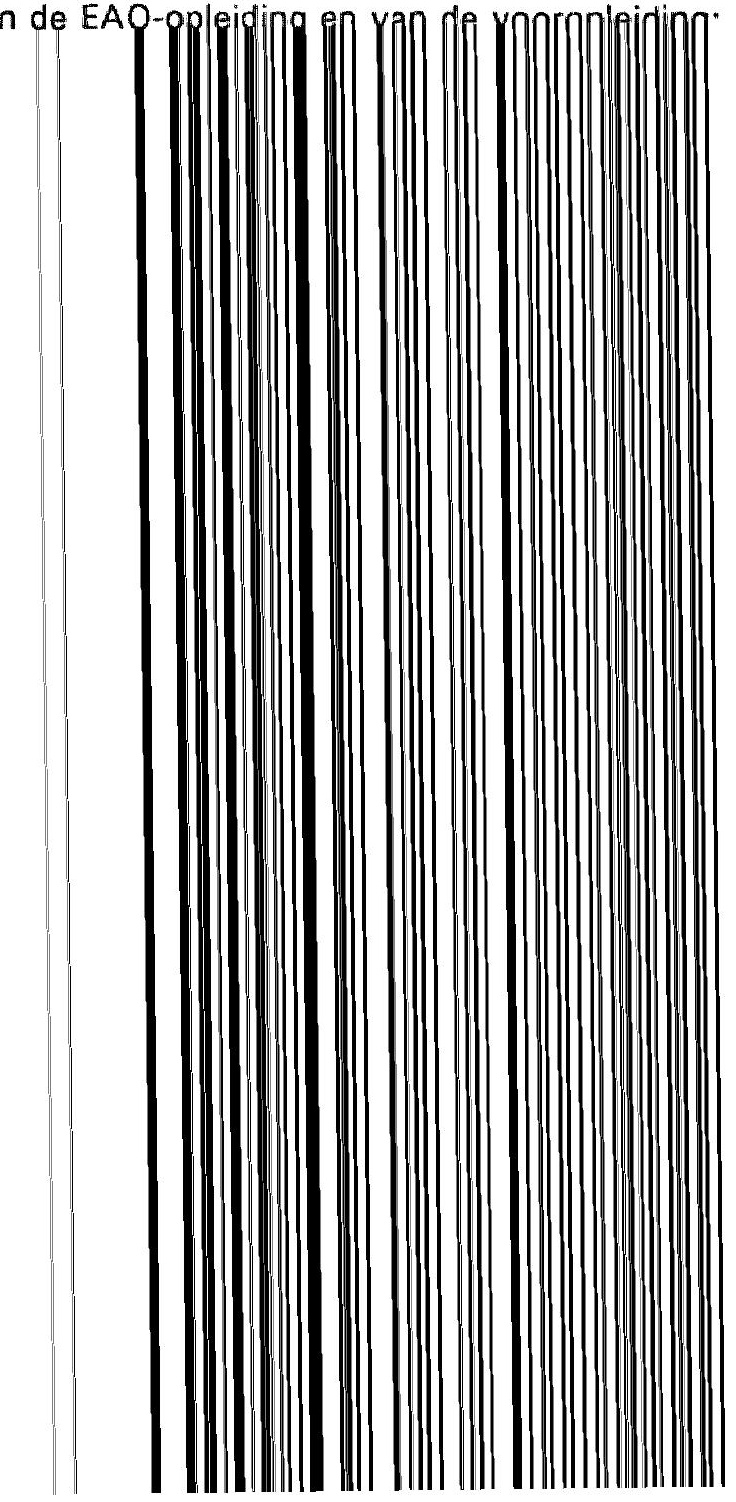




\section{PERSOONSKENMERKEN EN GENOTEN OPLEIDING}

\subsection{Inleiding}

De aan de EAO-school gevolgde vakrichting alsmede het resultaat waarmee men deze opleiding heeft verlaten, vormt de eerste invalshoek van waaruit de arbeidsmarktbestemming inzichtelijk kan worden gemaakt. De verklaring van eventuele verschillen in arbeidsmarktbestemming die zich beperkt tot het aspect vakrichting en opleidingsresultaat is onvolledig, omdat de mate van succes op de arbeidsmarkt ook kan afhangen van extra kwalificaties in de vorm van een voltooide vooropleiding en een aantal individuele achtergrondkenmerken van de schoolverlaters.

In dit hoofdstuk worden de onderzochte EAO-schoolverlaters achtereenvolgens beschreven aan de hand van een aantal achtergrondkenmerken. Het gaat hierbij om een drietal persoonsgerelateerde kenmerken en een aantal kenmerken van de EAQ-opleiding en Yan fe Yonrnn|fiding

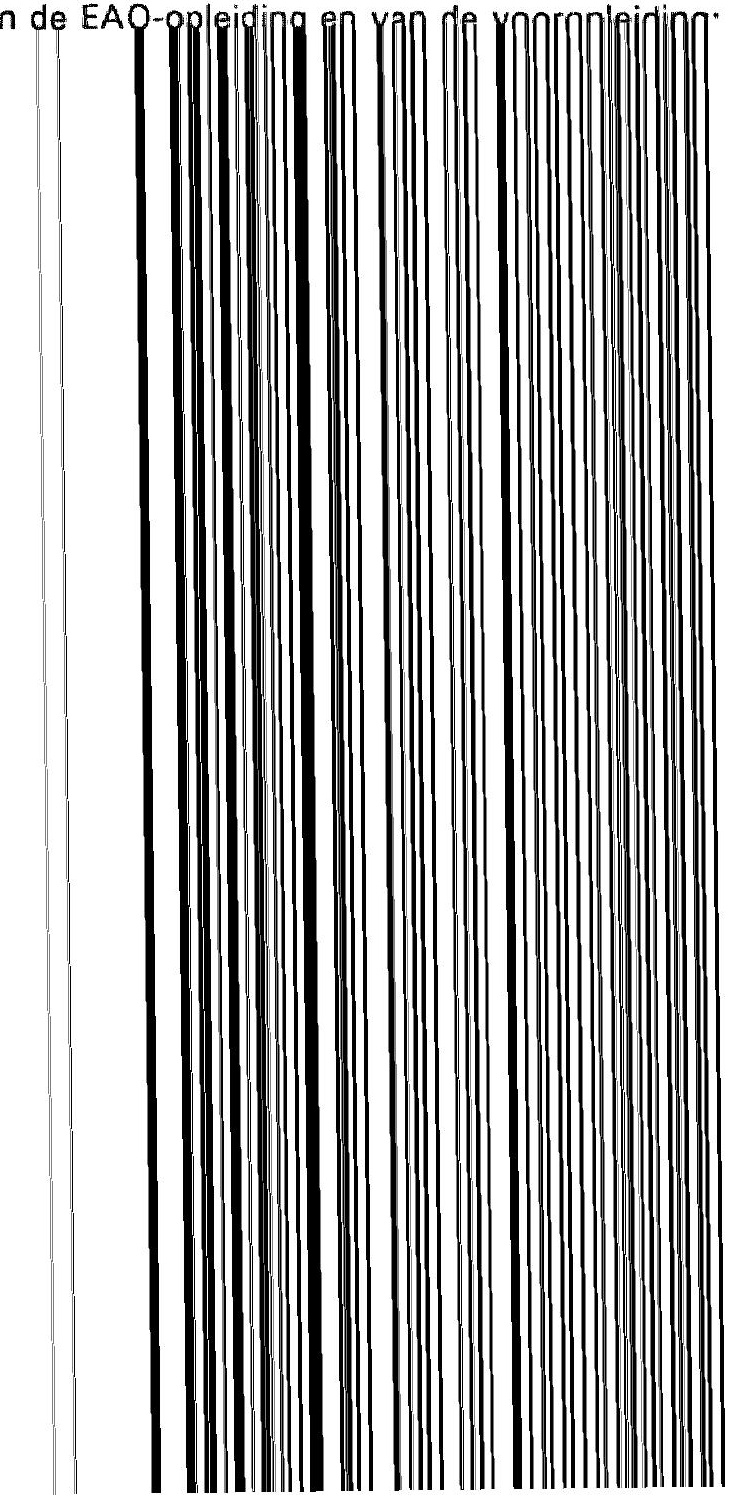




\section{PERSOONSKENMERKEN EN GENOTEN OPLEIDING}

\subsection{Inleiding}

De aan de EAO-school gevolgde vakrichting alsmede het resultaat waarmee men deze opleiding heeft verlaten, vormt de eerste invalshoek van waaruit de arbeidsmarktbestemming inzichtelijk kan worden gemaakt. De verklaring van eventuele verschillen in arbeidsmarktbestemming die zich beperkt tot het aspect vakrichting en opleidingsresultaat is onvolledig, omdat de mate van succes op de arbeidsmarkt ook kan afhangen van extra kwalificaties in de vorm van een voltooide vooropleiding en een aantal individuele achtergrondkenmerken van de schoolverlaters.

In dit hoofdstuk worden de onderzochte EAO-schoolverlaters achtereenvolgens beschreven aan de hand van een aantal achtergrondkenmerken. Het gaat hierbij om een drietal persoonsgerelateerde kenmerken en een aantal kenmerken van de EAQ-opleiding en Yan fe Yonrnn|fiding

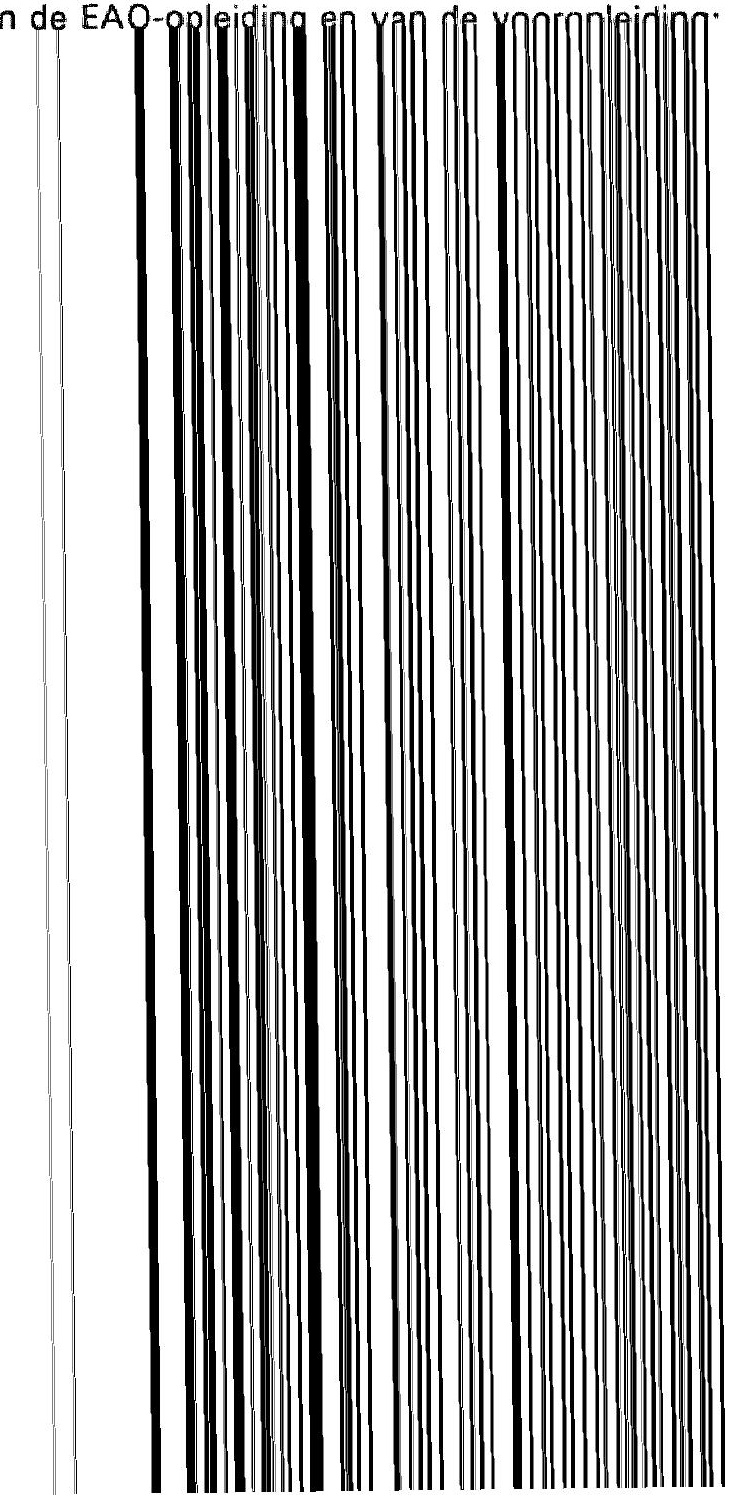




\section{PERSOONSKENMERKEN EN GENOTEN OPLEIDING}

\subsection{Inleiding}

De aan de EAO-school gevolgde vakrichting alsmede het resultaat waarmee men deze opleiding heeft verlaten, vormt de eerste invalshoek van waaruit de arbeidsmarktbestemming inzichtelijk kan worden gemaakt. De verklaring van eventuele verschillen in arbeidsmarktbestemming die zich beperkt tot het aspect vakrichting en opleidingsresultaat is onvolledig, omdat de mate van succes op de arbeidsmarkt ook kan afhangen van extra kwalificaties in de vorm van een voltooide vooropleiding en een aantal individuele achtergrondkenmerken van de schoolverlaters.

In dit hoofdstuk worden de onderzochte EAO-schoolverlaters achtereenvolgens beschreven aan de hand van een aantal achtergrondkenmerken. Het gaat hierbij om een drietal persoonsgerelateerde kenmerken en een aantal kenmerken van de EAQ-opleiding en Yan fe Yonrnn|fiding

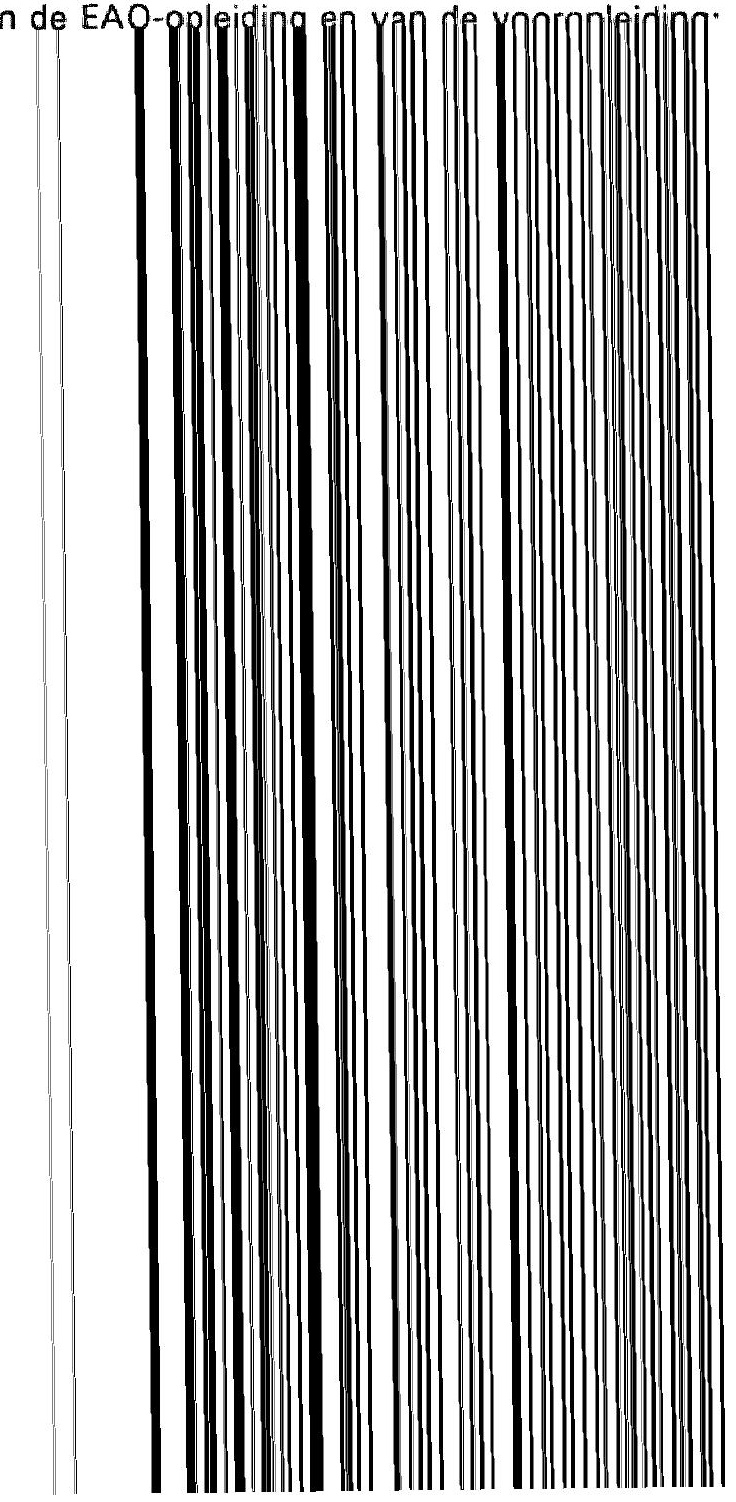




\section{PERSOONSKENMERKEN EN GENOTEN OPLEIDING}

\subsection{Inleiding}

De aan de EAO-school gevolgde vakrichting alsmede het resultaat waarmee men deze opleiding heeft verlaten, vormt de eerste invalshoek van waaruit de arbeidsmarktbestemming inzichtelijk kan worden gemaakt. De verklaring van eventuele verschillen in arbeidsmarktbestemming die zich beperkt tot het aspect vakrichting en opleidingsresultaat is onvolledig, omdat de mate van succes op de arbeidsmarkt ook kan afhangen van extra kwalificaties in de vorm van een voltooide vooropleiding en een aantal individuele achtergrondkenmerken van de schoolverlaters.

In dit hoofdstuk worden de onderzochte EAO-schoolverlaters achtereenvolgens beschreven aan de hand van een aantal achtergrondkenmerken. Het gaat hierbij om een drietal persoonsgerelateerde kenmerken en een aantal kenmerken van de EAQ-opleiding en Yan fe Yonrnn|fiding

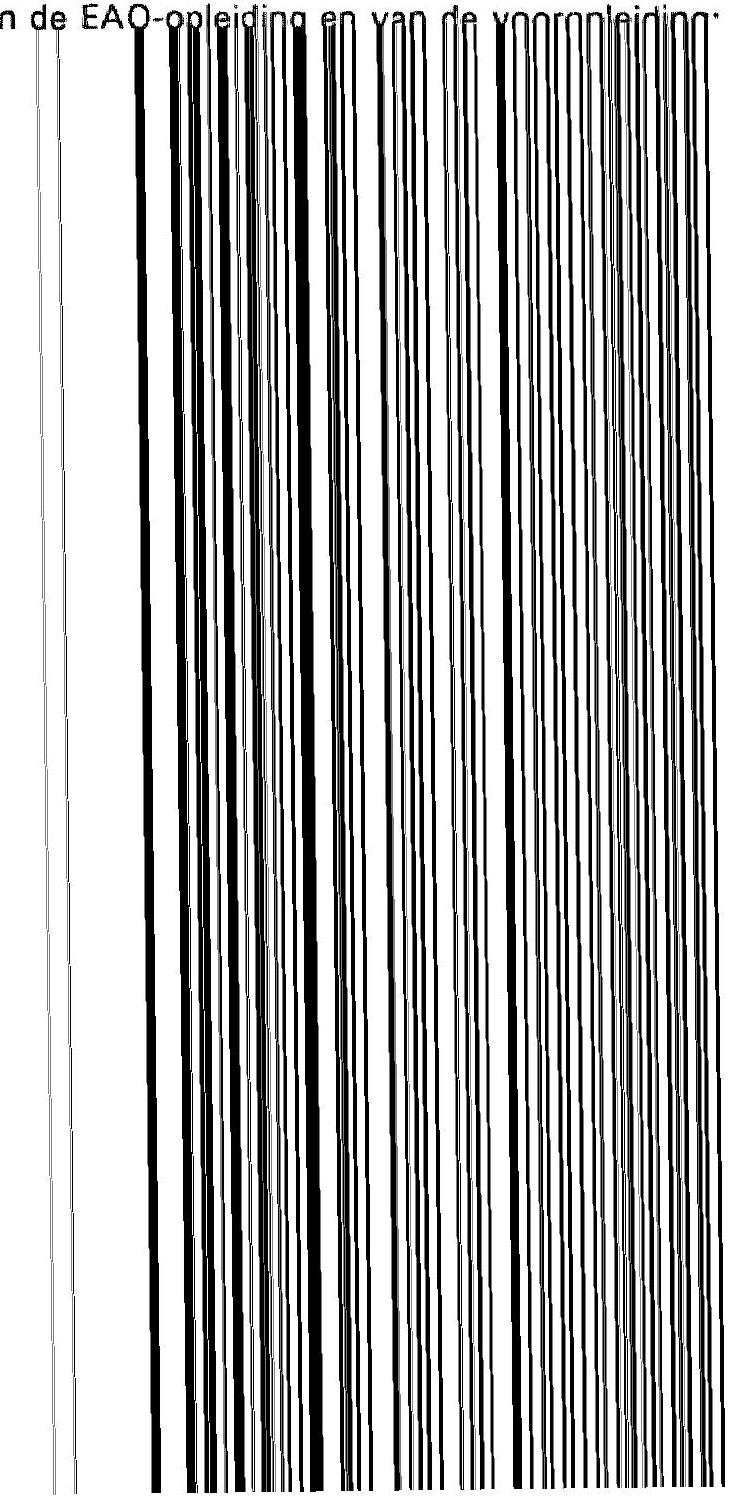




\section{PERSOONSKENMERKEN EN GENOTEN OPLEIDING}

\subsection{Inleiding}

De aan de EAO-school gevolgde vakrichting alsmede het resultaat waarmee men deze opleiding heeft verlaten, vormt de eerste invalshoek van waaruit de arbeidsmarktbestemming inzichtelijk kan worden gemaakt. De verklaring van eventuele verschillen in arbeidsmarktbestemming die zich beperkt tot het aspect vakrichting en opleidingsresultaat is onvolledig, omdat de mate van succes op de arbeidsmarkt ook kan afhangen van extra kwalificaties in de vorm van een voltooide vooropleiding en een aantal individuele achtergrondkenmerken van de schoolverlaters.

In dit hoofdstuk worden de onderzochte EAO-schoolverlaters achtereenvolgens beschreven aan de hand van een aantal achtergrondkenmerken. Het gaat hierbij om een drietal persoonsgerelateerde kenmerken en een aantal kenmerken van de EAQ-opleiding en Yan fe Yonrnn|fiding

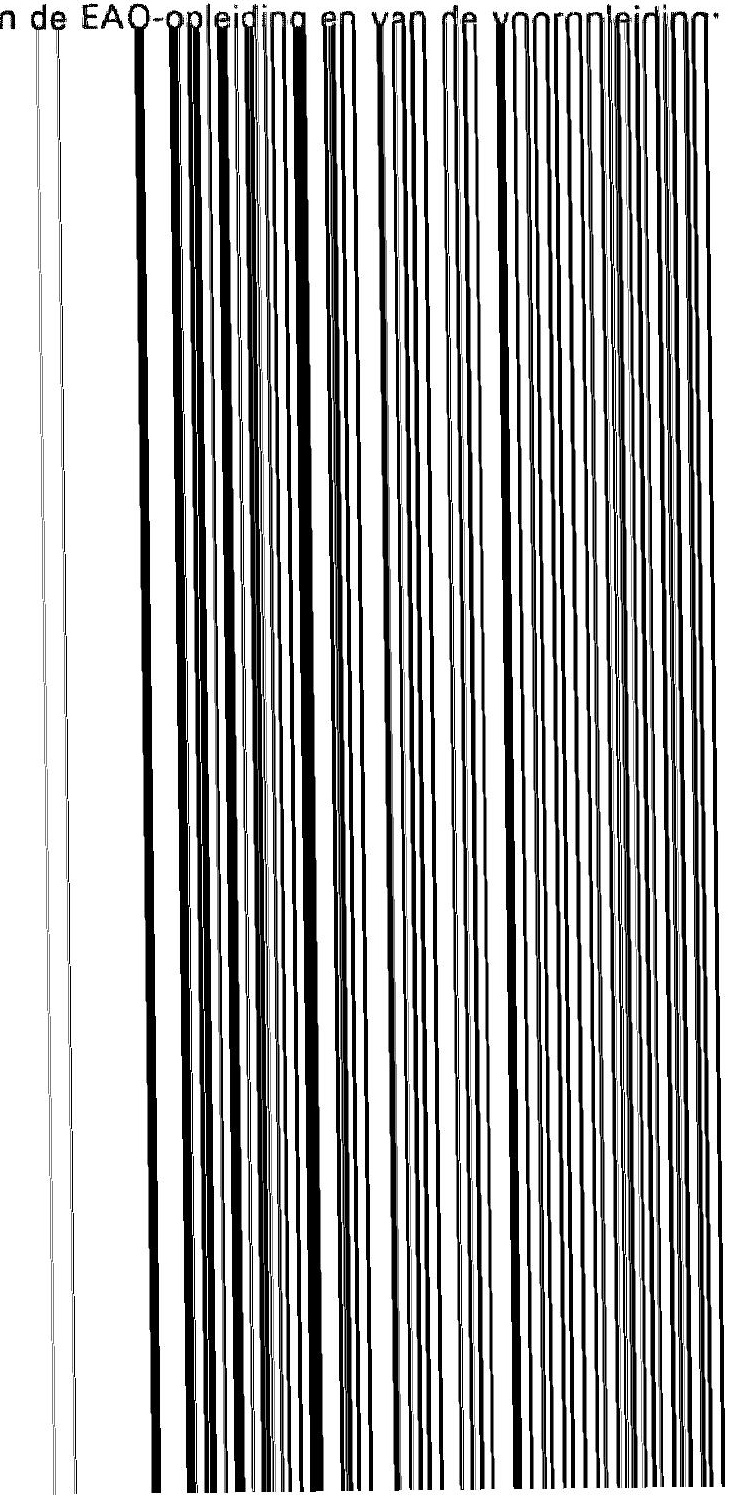




\section{PERSOONSKENMERKEN EN GENOTEN OPLEIDING}

\subsection{Inleiding}

De aan de EAO-school gevolgde vakrichting alsmede het resultaat waarmee men deze opleiding heeft verlaten, vormt de eerste invalshoek van waaruit de arbeidsmarktbestemming inzichtelijk kan worden gemaakt. De verklaring van eventuele verschillen in arbeidsmarktbestemming die zich beperkt tot het aspect vakrichting en opleidingsresultaat is onvolledig, omdat de mate van succes op de arbeidsmarkt ook kan afhangen van extra kwalificaties in de vorm van een voltooide vooropleiding en een aantal individuele achtergrondkenmerken van de schoolverlaters.

In dit hoofdstuk worden de onderzochte EAO-schoolverlaters achtereenvolgens beschreven aan de hand van een aantal achtergrondkenmerken. Het gaat hierbij om een drietal persoonsgerelateerde kenmerken en een aantal kenmerken van de EAQ-opleiding en Yan fe Yonrnn|fiding

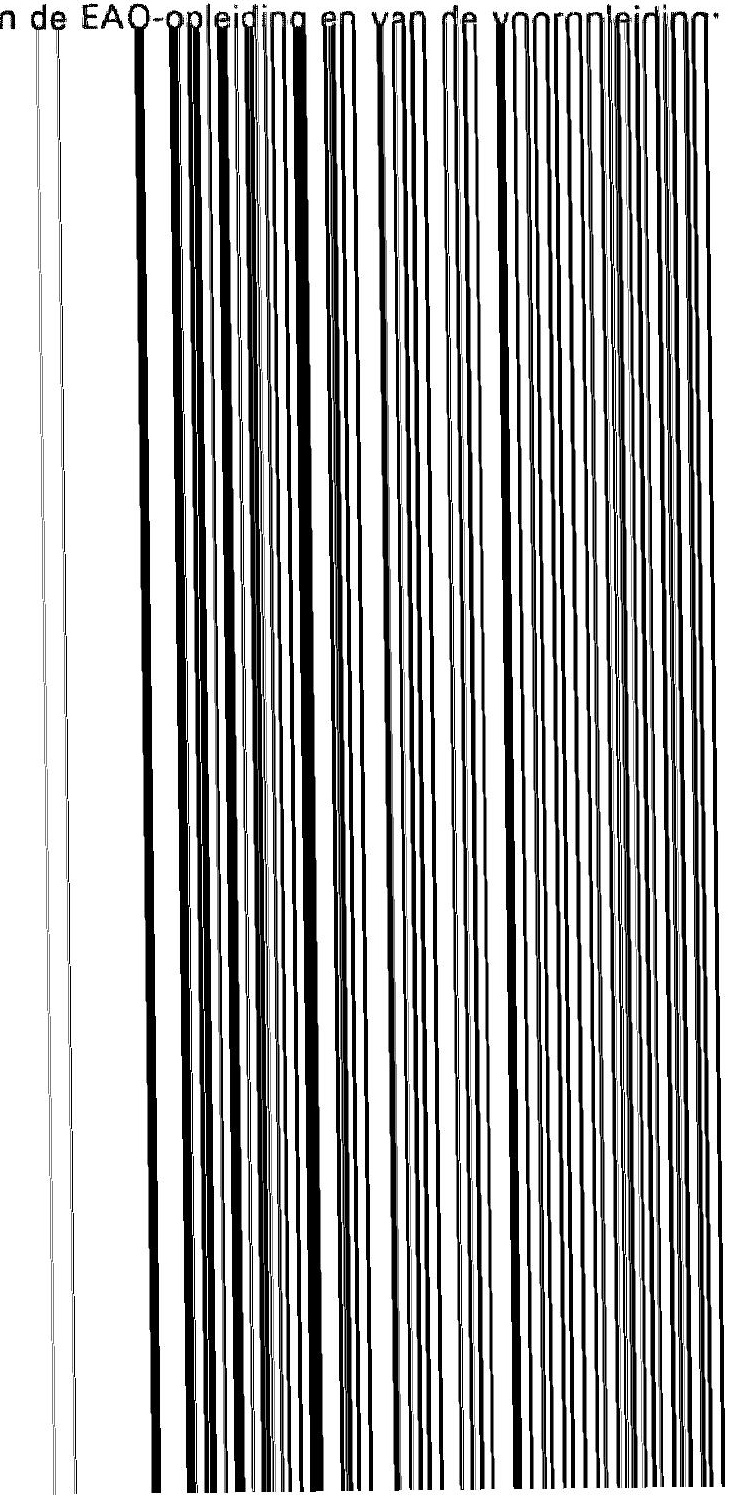




\section{PERSOONSKENMERKEN EN GENOTEN OPLEIDING}

\subsection{Inleiding}

De aan de EAO-school gevolgde vakrichting alsmede het resultaat waarmee men deze opleiding heeft verlaten, vormt de eerste invalshoek van waaruit de arbeidsmarktbestemming inzichtelijk kan worden gemaakt. De verklaring van eventuele verschillen in arbeidsmarktbestemming die zich beperkt tot het aspect vakrichting en opleidingsresultaat is onvolledig, omdat de mate van succes op de arbeidsmarkt ook kan afhangen van extra kwalificaties in de vorm van een voltooide vooropleiding en een aantal individuele achtergrondkenmerken van de schoolverlaters.

In dit hoofdstuk worden de onderzochte EAO-schoolverlaters achtereenvolgens beschreven aan de hand van een aantal achtergrondkenmerken. Het gaat hierbij om een drietal persoonsgerelateerde kenmerken en een aantal kenmerken van de EAQ-opleiding en Yan fe Yonrnn|fiding

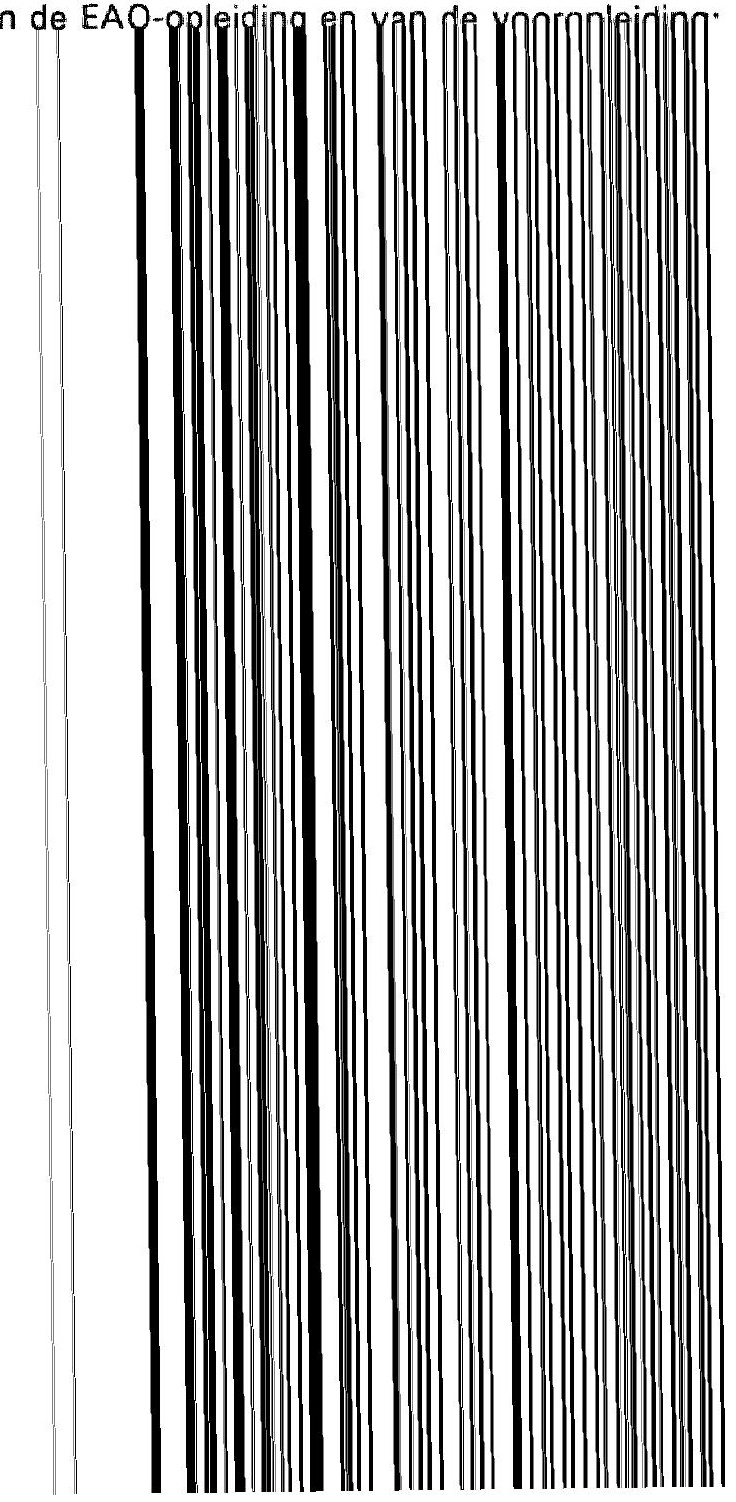




\section{PERSOONSKENMERKEN EN GENOTEN OPLEIDING}

\subsection{Inleiding}

De aan de EAO-school gevolgde vakrichting alsmede het resultaat waarmee men deze opleiding heeft verlaten, vormt de eerste invalshoek van waaruit de arbeidsmarktbestemming inzichtelijk kan worden gemaakt. De verklaring van eventuele verschillen in arbeidsmarktbestemming die zich beperkt tot het aspect vakrichting en opleidingsresultaat is onvolledig, omdat de mate van succes op de arbeidsmarkt ook kan afhangen van extra kwalificaties in de vorm van een voltooide vooropleiding en een aantal individuele achtergrondkenmerken van de schoolverlaters.

In dit hoofdstuk worden de onderzochte EAO-schoolverlaters achtereenvolgens beschreven aan de hand van een aantal achtergrondkenmerken. Het gaat hierbij om een drietal persoonsgerelateerde kenmerken en een aantal kenmerken van de EAQ-opleiding en Yan fe Yonrnn|fiding

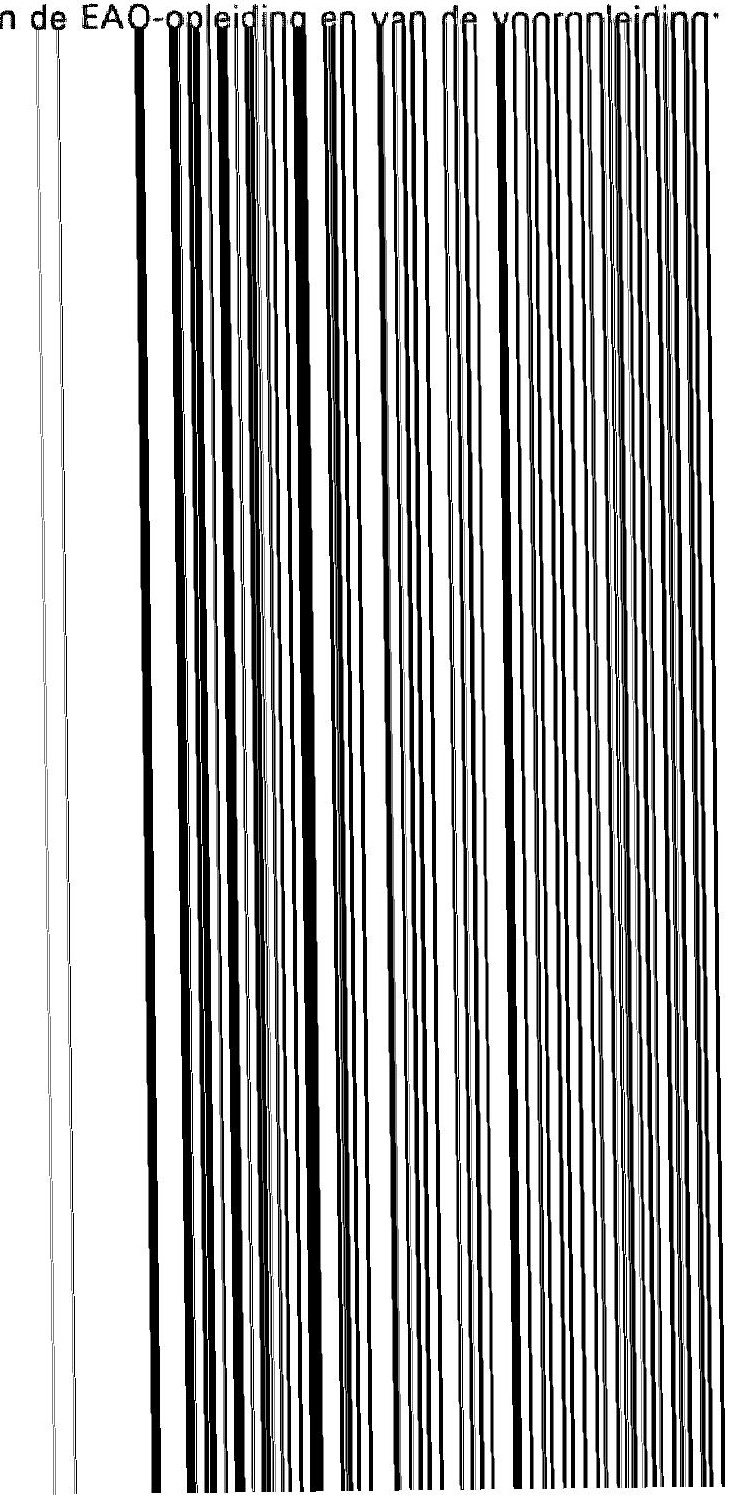




\section{PERSOONSKENMERKEN EN GENOTEN OPLEIDING}

\subsection{Inleiding}

De aan de EAO-school gevolgde vakrichting alsmede het resultaat waarmee men deze opleiding heeft verlaten, vormt de eerste invalshoek van waaruit de arbeidsmarktbestemming inzichtelijk kan worden gemaakt. De verklaring van eventuele verschillen in arbeidsmarktbestemming die zich beperkt tot het aspect vakrichting en opleidingsresultaat is onvolledig, omdat de mate van succes op de arbeidsmarkt ook kan afhangen van extra kwalificaties in de vorm van een voltooide vooropleiding en een aantal individuele achtergrondkenmerken van de schoolverlaters.

In dit hoofdstuk worden de onderzochte EAO-schoolverlaters achtereenvolgens beschreven aan de hand van een aantal achtergrondkenmerken. Het gaat hierbij om een drietal persoonsgerelateerde kenmerken en een aantal kenmerken van de EAQ-opleiding en Yan fe Yonrnn|fiding

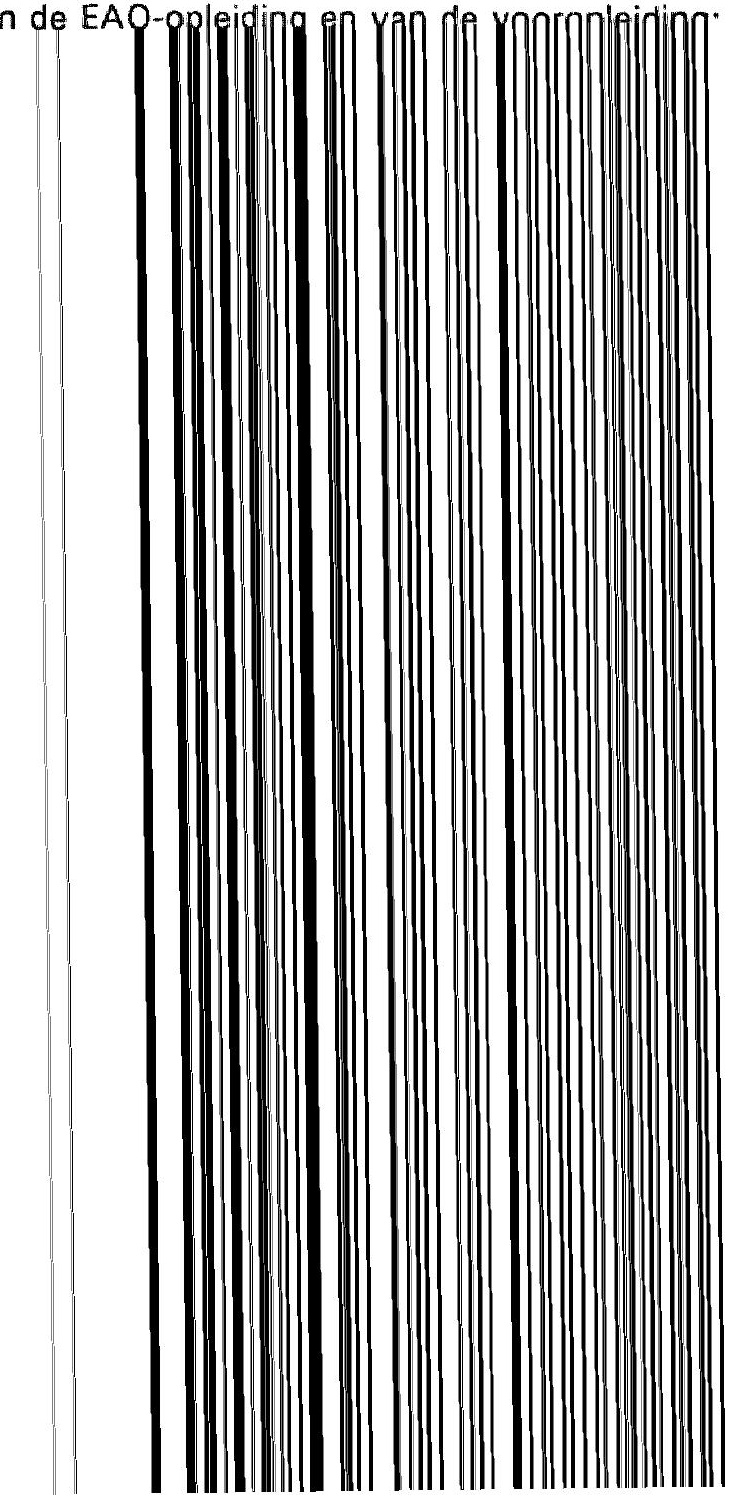




\section{PERSOONSKENMERKEN EN GENOTEN OPLEIDING}

\subsection{Inleiding}

De aan de EAO-school gevolgde vakrichting alsmede het resultaat waarmee men deze opleiding heeft verlaten, vormt de eerste invalshoek van waaruit de arbeidsmarktbestemming inzichtelijk kan worden gemaakt. De verklaring van eventuele verschillen in arbeidsmarktbestemming die zich beperkt tot het aspect vakrichting en opleidingsresultaat is onvolledig, omdat de mate van succes op de arbeidsmarkt ook kan afhangen van extra kwalificaties in de vorm van een voltooide vooropleiding en een aantal individuele achtergrondkenmerken van de schoolverlaters.

In dit hoofdstuk worden de onderzochte EAO-schoolverlaters achtereenvolgens beschreven aan de hand van een aantal achtergrondkenmerken. Het gaat hierbij om een drietal persoonsgerelateerde kenmerken en een aantal kenmerken van de EAQ-opleiding en Yan fe Yonrnn|fiding

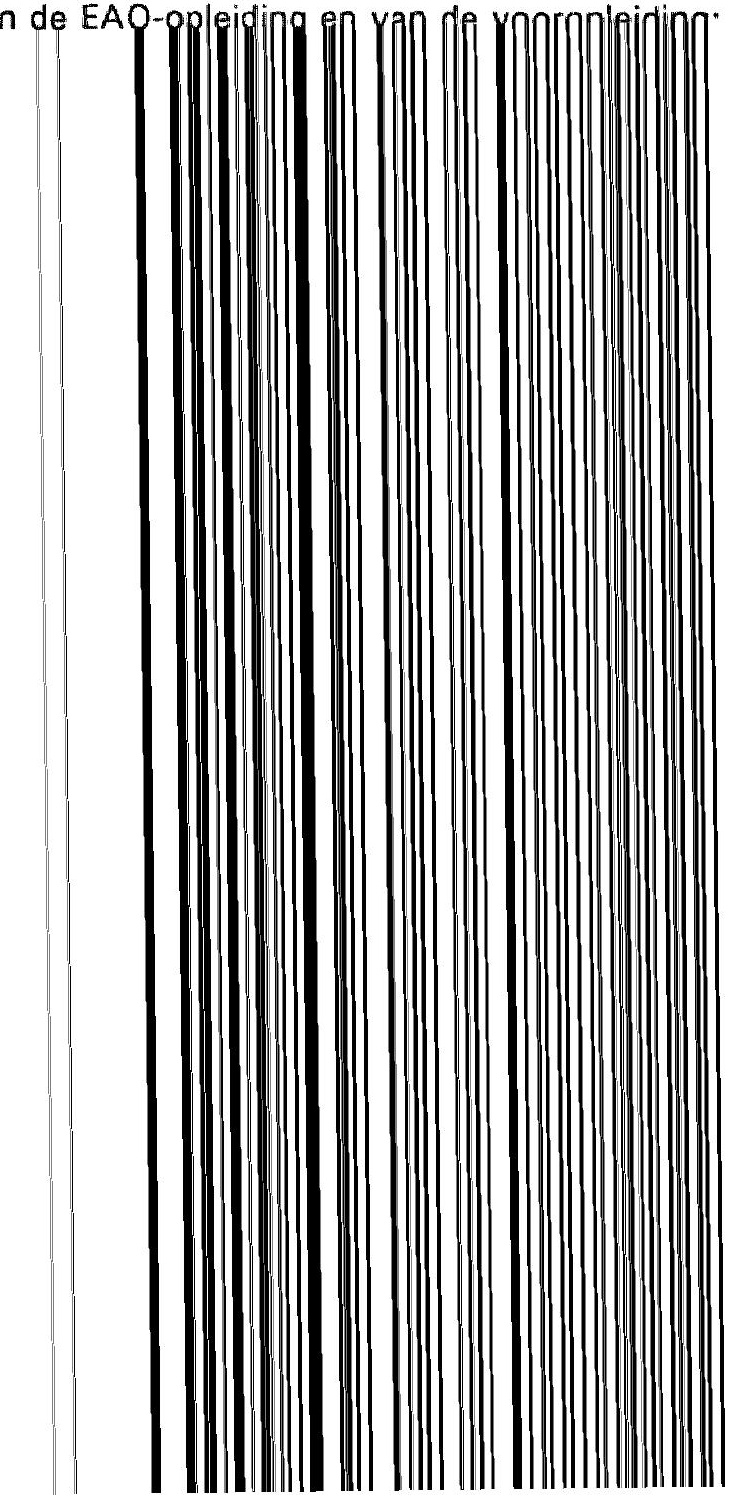




\section{PERSOONSKENMERKEN EN GENOTEN OPLEIDING}

\subsection{Inleiding}

De aan de EAO-school gevolgde vakrichting alsmede het resultaat waarmee men deze opleiding heeft verlaten, vormt de eerste invalshoek van waaruit de arbeidsmarktbestemming inzichtelijk kan worden gemaakt. De verklaring van eventuele verschillen in arbeidsmarktbestemming die zich beperkt tot het aspect vakrichting en opleidingsresultaat is onvolledig, omdat de mate van succes op de arbeidsmarkt ook kan afhangen van extra kwalificaties in de vorm van een voltooide vooropleiding en een aantal individuele achtergrondkenmerken van de schoolverlaters.

In dit hoofdstuk worden de onderzochte EAO-schoolverlaters achtereenvolgens beschreven aan de hand van een aantal achtergrondkenmerken. Het gaat hierbij om een drietal persoonsgerelateerde kenmerken en een aantal kenmerken van de EAQ-opleiding en Yan fe Yonrnn|fiding

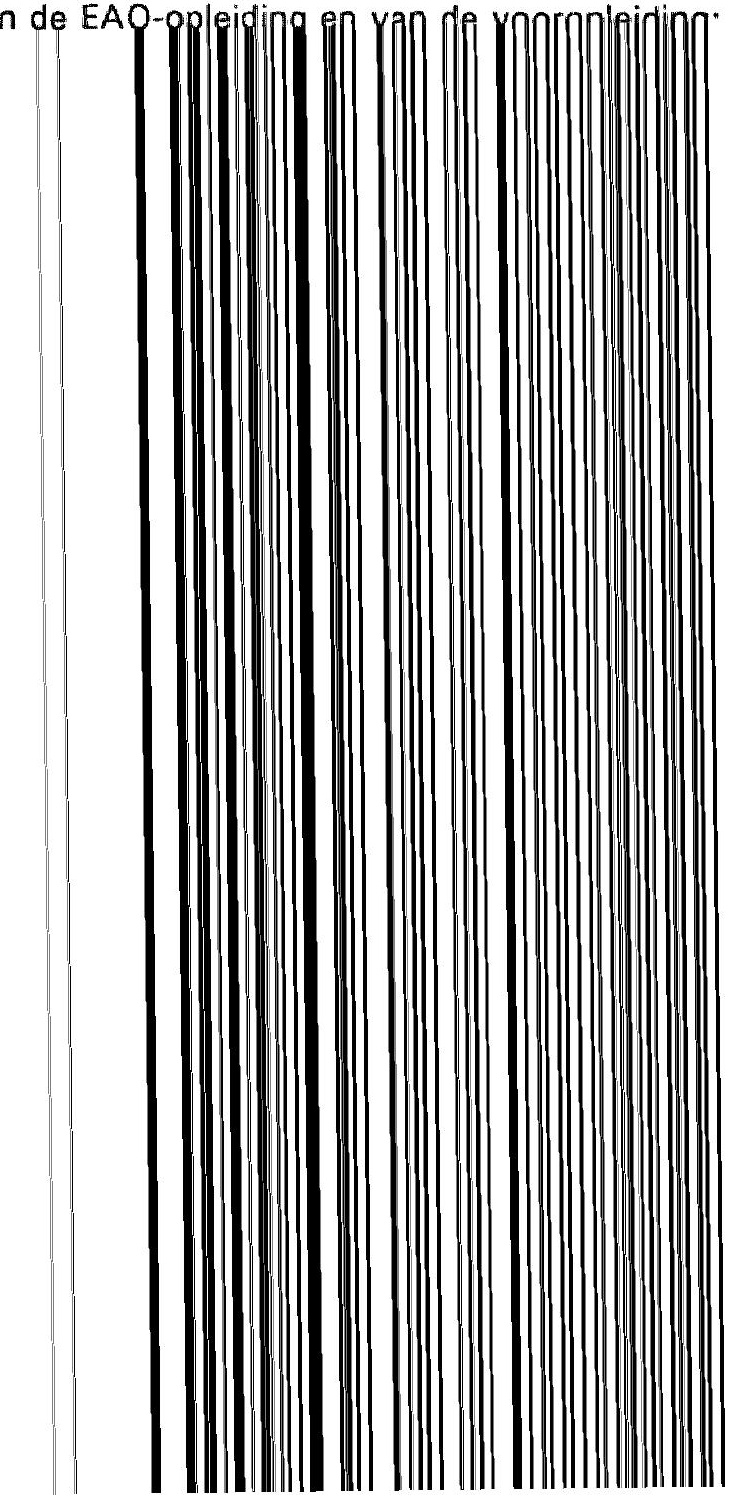




\section{PERSOONSKENMERKEN EN GENOTEN OPLEIDING}

\subsection{Inleiding}

De aan de EAO-school gevolgde vakrichting alsmede het resultaat waarmee men deze opleiding heeft verlaten, vormt de eerste invalshoek van waaruit de arbeidsmarktbestemming inzichtelijk kan worden gemaakt. De verklaring van eventuele verschillen in arbeidsmarktbestemming die zich beperkt tot het aspect vakrichting en opleidingsresultaat is onvolledig, omdat de mate van succes op de arbeidsmarkt ook kan afhangen van extra kwalificaties in de vorm van een voltooide vooropleiding en een aantal individuele achtergrondkenmerken van de schoolverlaters.

In dit hoofdstuk worden de onderzochte EAO-schoolverlaters achtereenvolgens beschreven aan de hand van een aantal achtergrondkenmerken. Het gaat hierbij om een drietal persoonsgerelateerde kenmerken en een aantal kenmerken van de EAQ-opleiding en Yan fe Yonrnn|fiding

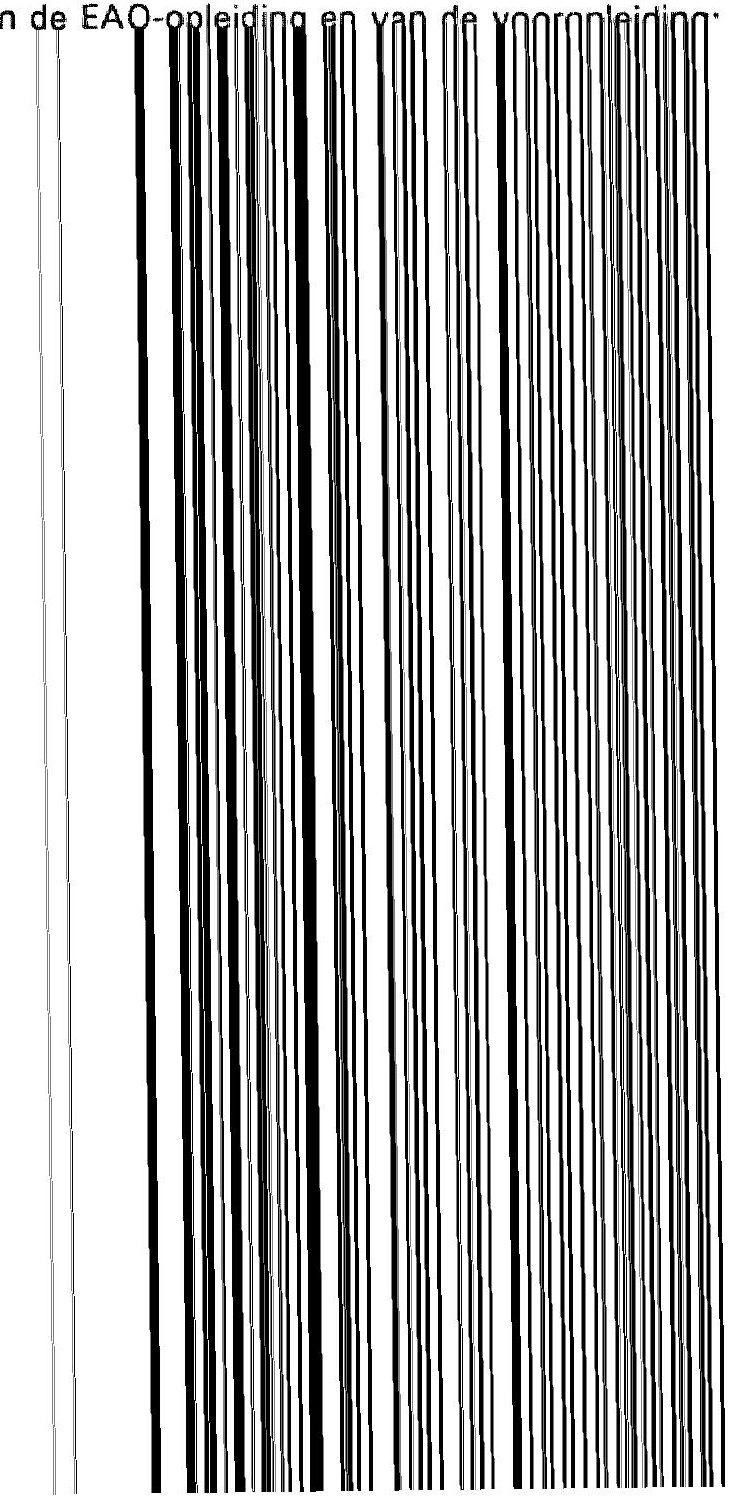




\section{PERSOONSKENMERKEN EN GENOTEN OPLEIDING}

\subsection{Inleiding}

De aan de EAO-school gevolgde vakrichting alsmede het resultaat waarmee men deze opleiding heeft verlaten, vormt de eerste invalshoek van waaruit de arbeidsmarktbestemming inzichtelijk kan worden gemaakt. De verklaring van eventuele verschillen in arbeidsmarktbestemming die zich beperkt tot het aspect vakrichting en opleidingsresultaat is onvolledig, omdat de mate van succes op de arbeidsmarkt ook kan afhangen van extra kwalificaties in de vorm van een voltooide vooropleiding en een aantal individuele achtergrondkenmerken van de schoolverlaters.

In dit hoofdstuk worden de onderzochte EAO-schoolverlaters achtereenvolgens beschreven aan de hand van een aantal achtergrondkenmerken. Het gaat hierbij om een drietal persoonsgerelateerde kenmerken en een aantal kenmerken van de EAQ-opleiding en Yan fe Yonrnn|fiding

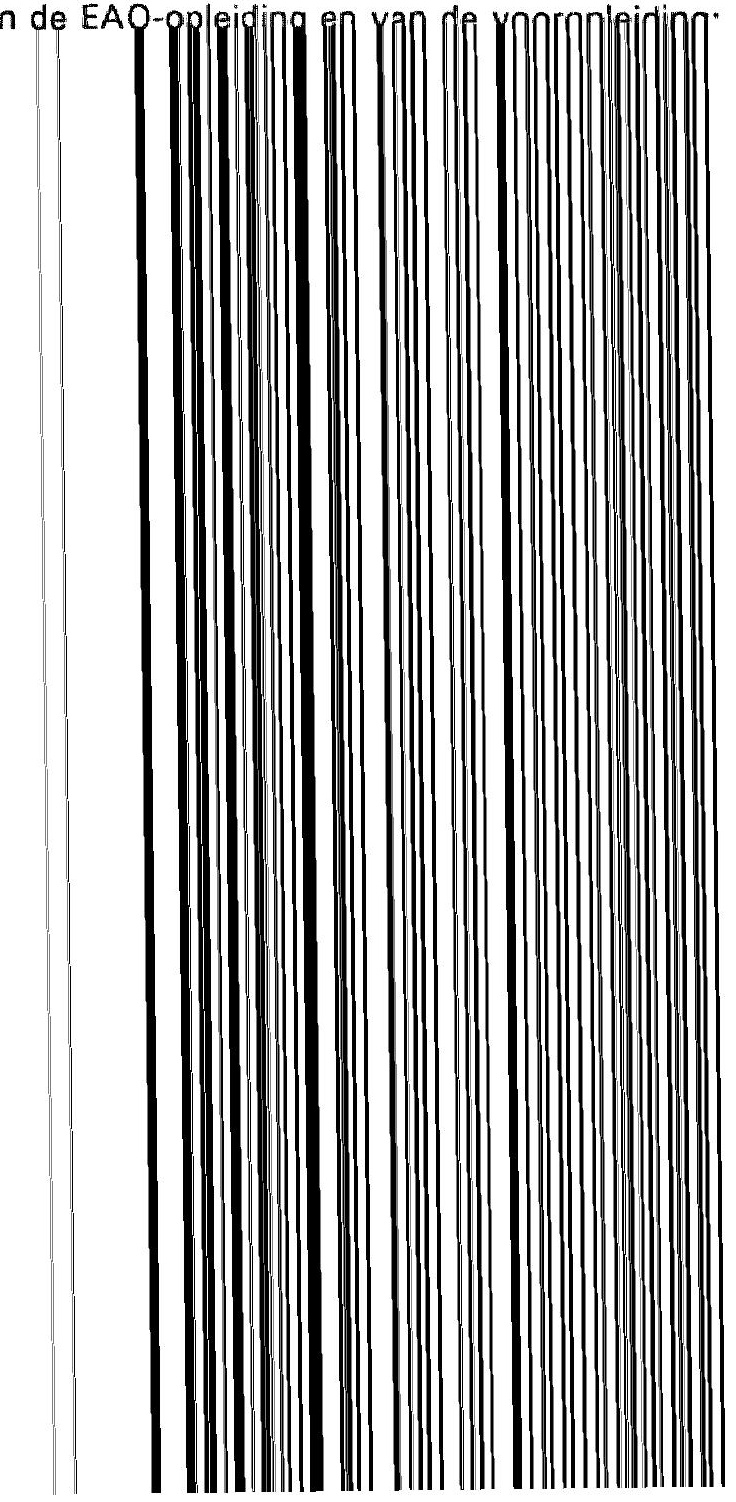




\section{PERSOONSKENMERKEN EN GENOTEN OPLEIDING}

\subsection{Inleiding}

De aan de EAO-school gevolgde vakrichting alsmede het resultaat waarmee men deze opleiding heeft verlaten, vormt de eerste invalshoek van waaruit de arbeidsmarktbestemming inzichtelijk kan worden gemaakt. De verklaring van eventuele verschillen in arbeidsmarktbestemming die zich beperkt tot het aspect vakrichting en opleidingsresultaat is onvolledig, omdat de mate van succes op de arbeidsmarkt ook kan afhangen van extra kwalificaties in de vorm van een voltooide vooropleiding en een aantal individuele achtergrondkenmerken van de schoolverlaters.

In dit hoofdstuk worden de onderzochte EAO-schoolverlaters achtereenvolgens beschreven aan de hand van een aantal achtergrondkenmerken. Het gaat hierbij om een drietal persoonsgerelateerde kenmerken en een aantal kenmerken van de EAQ-opleiding en Yan fe Yonrnn|fiding

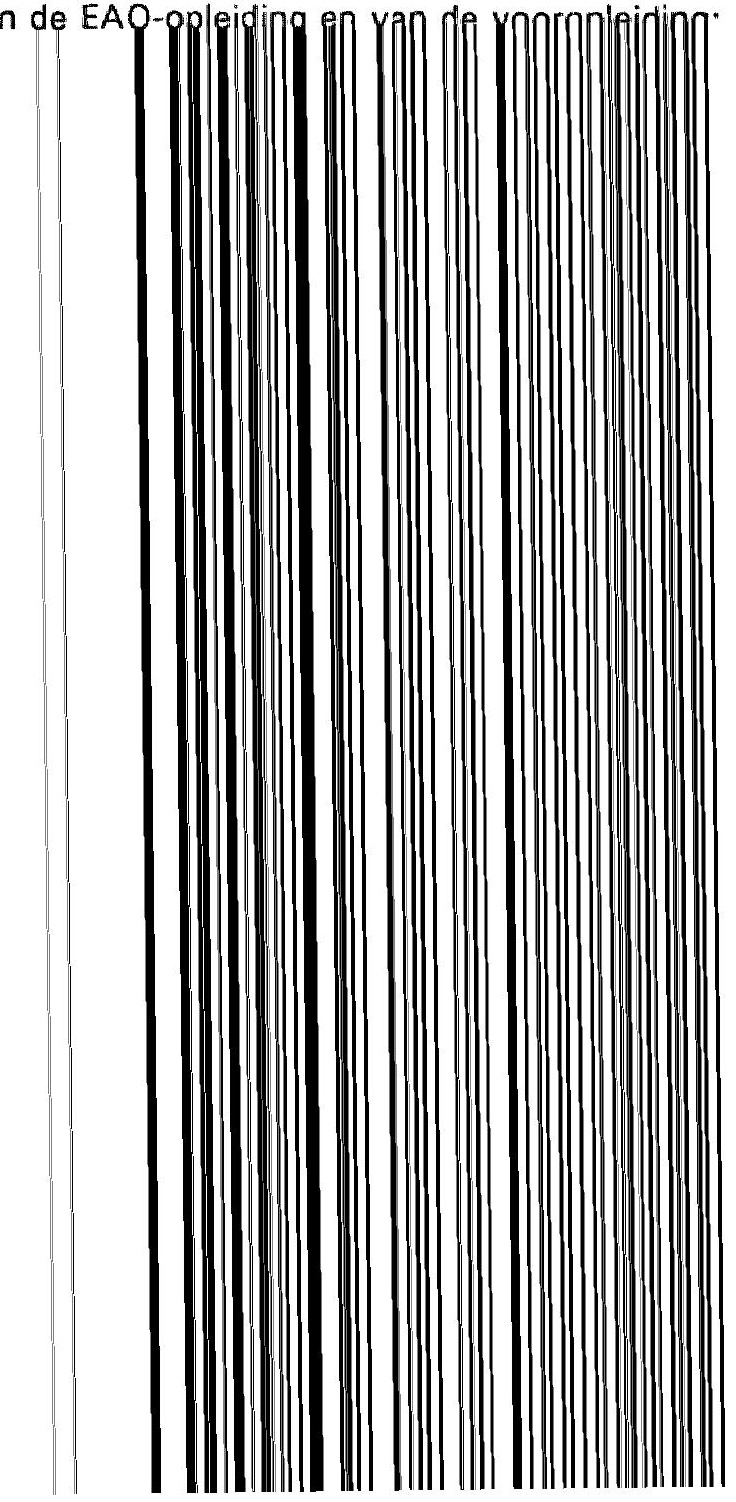




\section{PERSOONSKENMERKEN EN GENOTEN OPLEIDING}

\subsection{Inleiding}

De aan de EAO-school gevolgde vakrichting alsmede het resultaat waarmee men deze opleiding heeft verlaten, vormt de eerste invalshoek van waaruit de arbeidsmarktbestemming inzichtelijk kan worden gemaakt. De verklaring van eventuele verschillen in arbeidsmarktbestemming die zich beperkt tot het aspect vakrichting en opleidingsresultaat is onvolledig, omdat de mate van succes op de arbeidsmarkt ook kan afhangen van extra kwalificaties in de vorm van een voltooide vooropleiding en een aantal individuele achtergrondkenmerken van de schoolverlaters.

In dit hoofdstuk worden de onderzochte EAO-schoolverlaters achtereenvolgens beschreven aan de hand van een aantal achtergrondkenmerken. Het gaat hierbij om een drietal persoonsgerelateerde kenmerken en een aantal kenmerken van de EAQ-opleiding en Yan fe Yonrnn|fiding

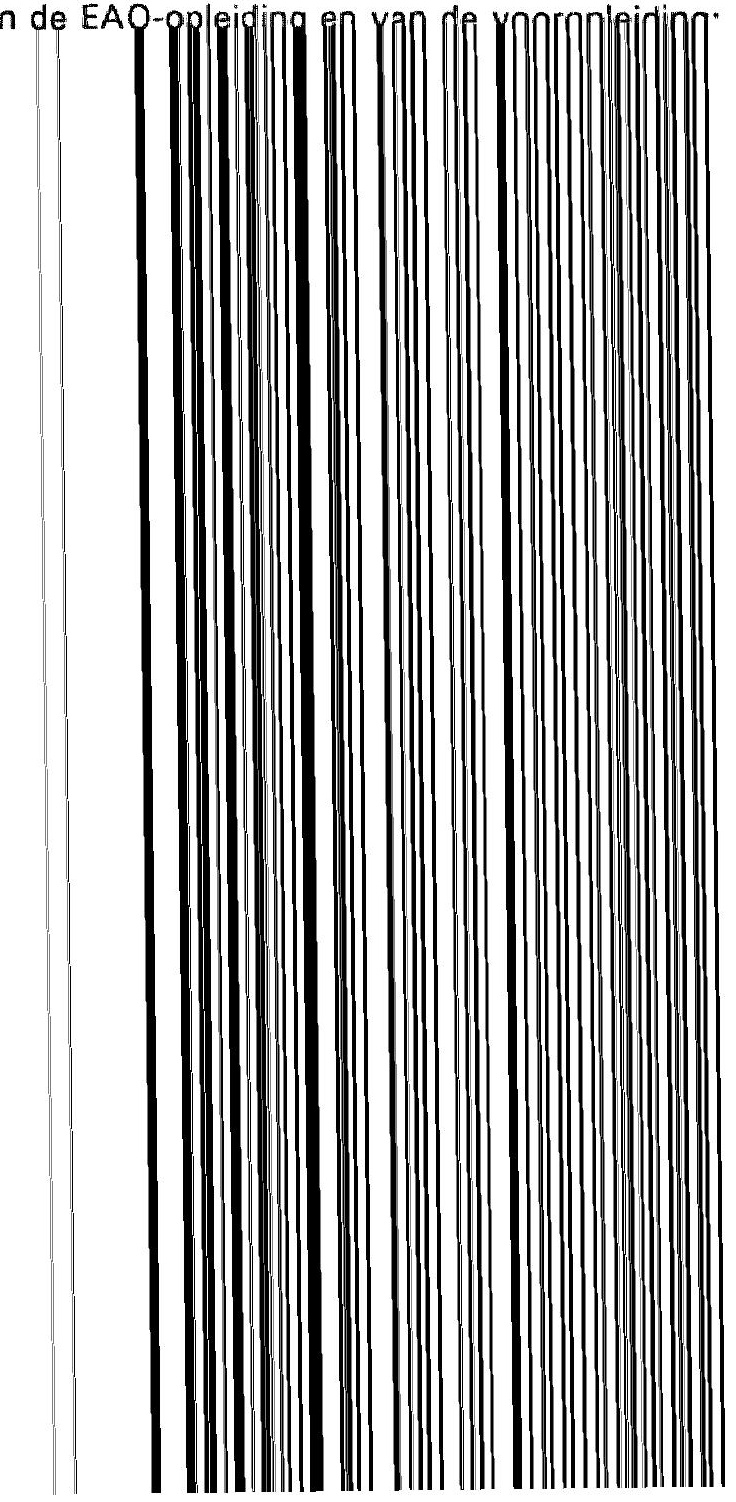




\section{PERSOONSKENMERKEN EN GENOTEN OPLEIDING}

\subsection{Inleiding}

De aan de EAO-school gevolgde vakrichting alsmede het resultaat waarmee men deze opleiding heeft verlaten, vormt de eerste invalshoek van waaruit de arbeidsmarktbestemming inzichtelijk kan worden gemaakt. De verklaring van eventuele verschillen in arbeidsmarktbestemming die zich beperkt tot het aspect vakrichting en opleidingsresultaat is onvolledig, omdat de mate van succes op de arbeidsmarkt ook kan afhangen van extra kwalificaties in de vorm van een voltooide vooropleiding en een aantal individuele achtergrondkenmerken van de schoolverlaters.

In dit hoofdstuk worden de onderzochte EAO-schoolverlaters achtereenvolgens beschreven aan de hand van een aantal achtergrondkenmerken. Het gaat hierbij om een drietal persoonsgerelateerde kenmerken en een aantal kenmerken van de EAQ-opleiding en Yan fe Yonrnn|fiding

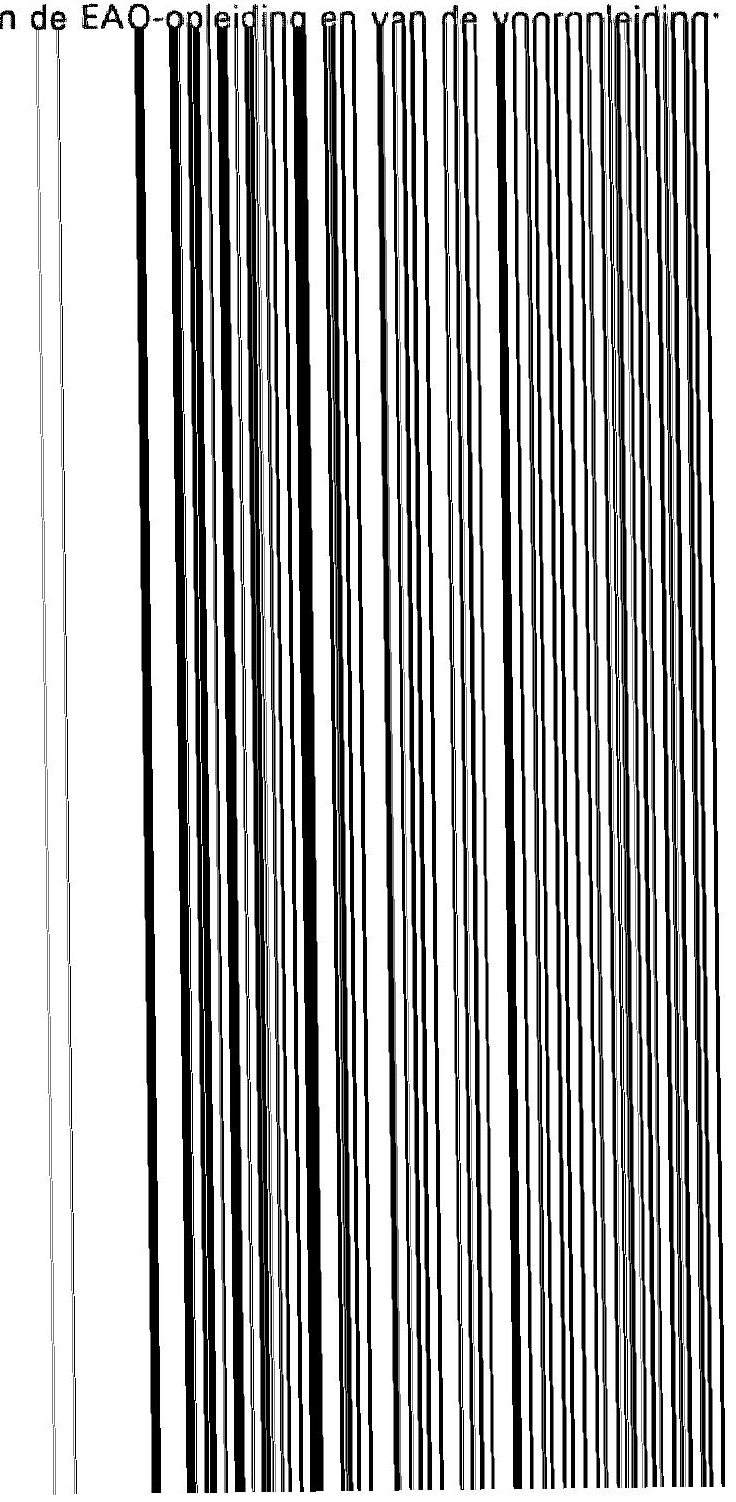




\section{PERSOONSKENMERKEN EN GENOTEN OPLEIDING}

\subsection{Inleiding}

De aan de EAO-school gevolgde vakrichting alsmede het resultaat waarmee men deze opleiding heeft verlaten, vormt de eerste invalshoek van waaruit de arbeidsmarktbestemming inzichtelijk kan worden gemaakt. De verklaring van eventuele verschillen in arbeidsmarktbestemming die zich beperkt tot het aspect vakrichting en opleidingsresultaat is onvolledig, omdat de mate van succes op de arbeidsmarkt ook kan afhangen van extra kwalificaties in de vorm van een voltooide vooropleiding en een aantal individuele achtergrondkenmerken van de schoolverlaters.

In dit hoofdstuk worden de onderzochte EAO-schoolverlaters achtereenvolgens beschreven aan de hand van een aantal achtergrondkenmerken. Het gaat hierbij om een drietal persoonsgerelateerde kenmerken en een aantal kenmerken van de EAQ-opleiding en Yan fe Yonrnn|fiding

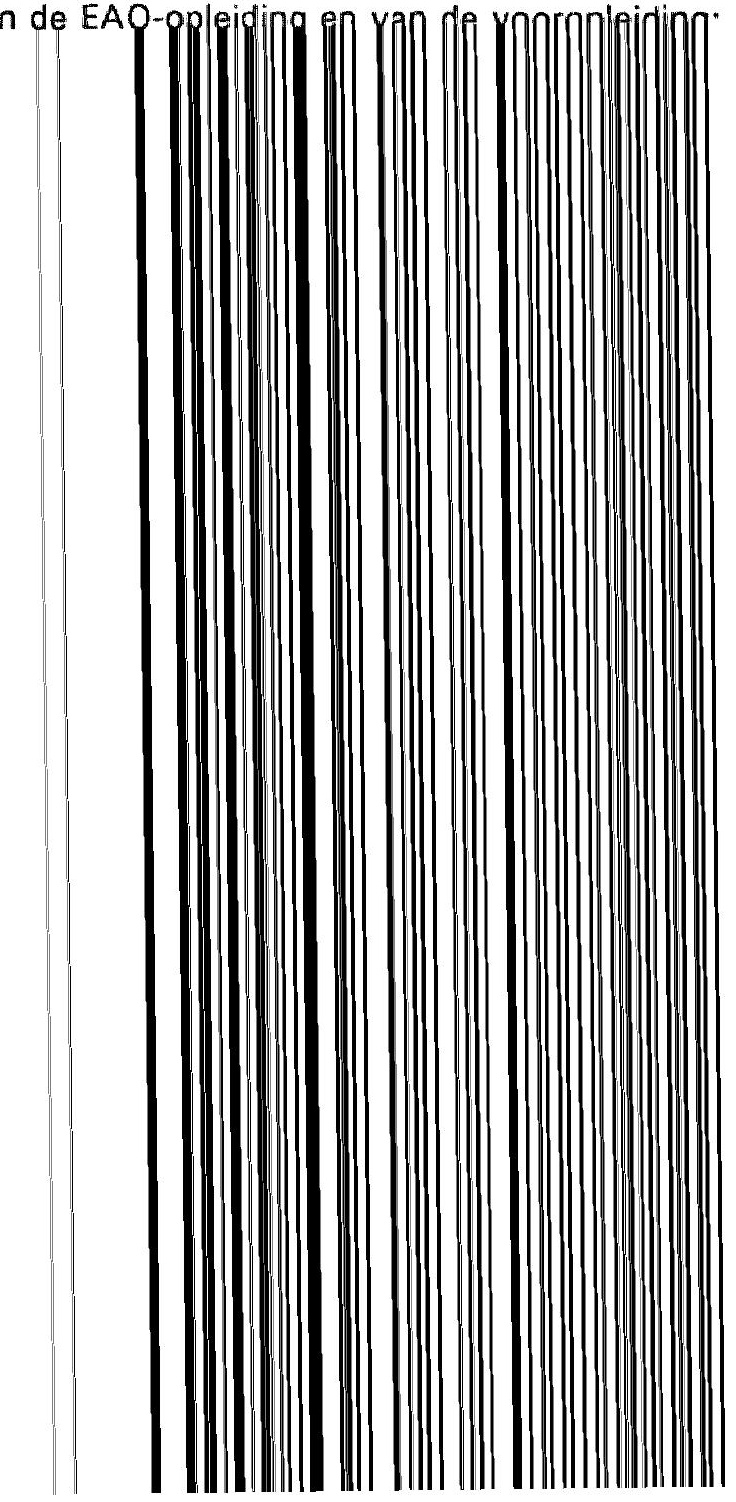




\section{PERSOONSKENMERKEN EN GENOTEN OPLEIDING}

\subsection{Inleiding}

De aan de EAO-school gevolgde vakrichting alsmede het resultaat waarmee men deze opleiding heeft verlaten, vormt de eerste invalshoek van waaruit de arbeidsmarktbestemming inzichtelijk kan worden gemaakt. De verklaring van eventuele verschillen in arbeidsmarktbestemming die zich beperkt tot het aspect vakrichting en opleidingsresultaat is onvolledig, omdat de mate van succes op de arbeidsmarkt ook kan afhangen van extra kwalificaties in de vorm van een voltooide vooropleiding en een aantal individuele achtergrondkenmerken van de schoolverlaters.

In dit hoofdstuk worden de onderzochte EAO-schoolverlaters achtereenvolgens beschreven aan de hand van een aantal achtergrondkenmerken. Het gaat hierbij om een drietal persoonsgerelateerde kenmerken en een aantal kenmerken van de EAQ-opleiding en Yan fe Yonrnn|fiding

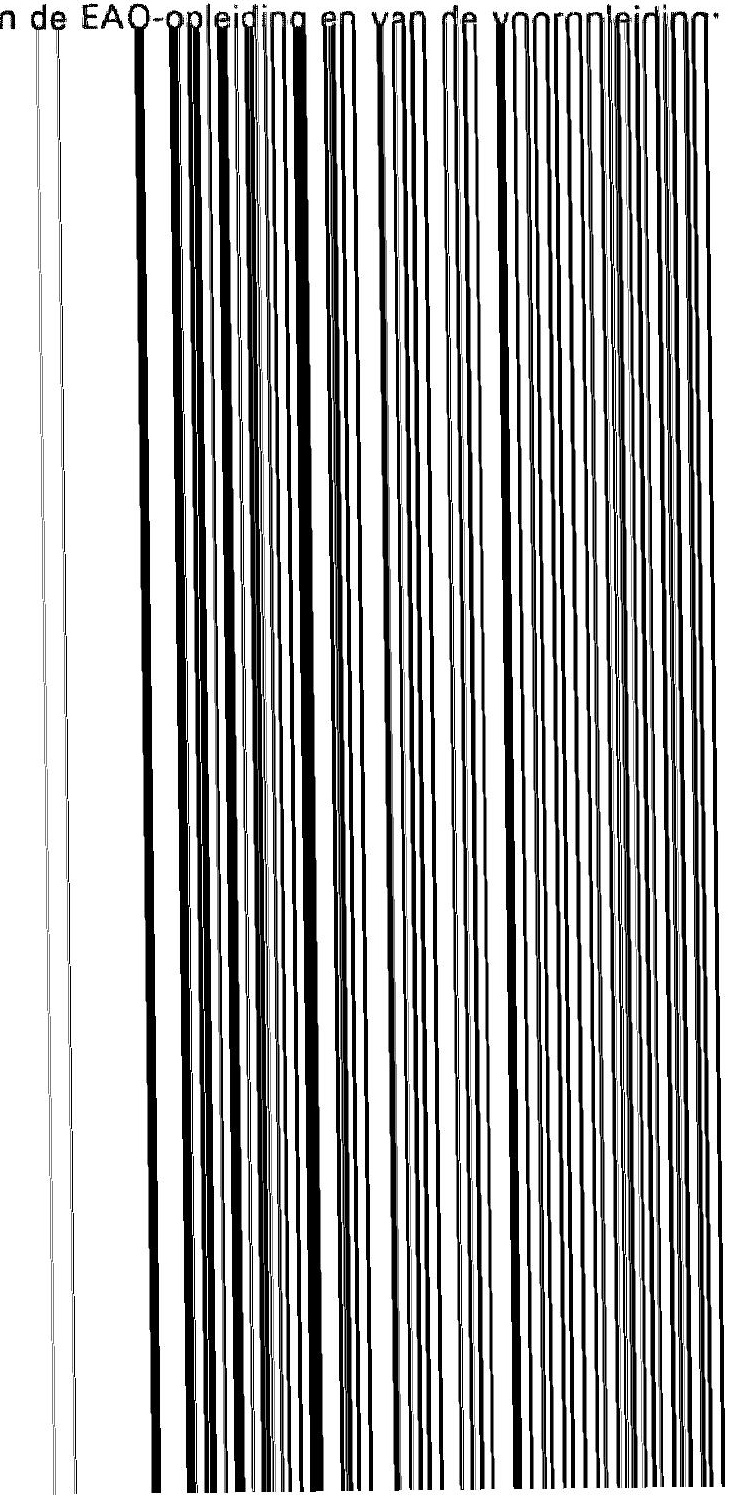




\section{PERSOONSKENMERKEN EN GENOTEN OPLEIDING}

\subsection{Inleiding}

De aan de EAO-school gevolgde vakrichting alsmede het resultaat waarmee men deze opleiding heeft verlaten, vormt de eerste invalshoek van waaruit de arbeidsmarktbestemming inzichtelijk kan worden gemaakt. De verklaring van eventuele verschillen in arbeidsmarktbestemming die zich beperkt tot het aspect vakrichting en opleidingsresultaat is onvolledig, omdat de mate van succes op de arbeidsmarkt ook kan afhangen van extra kwalificaties in de vorm van een voltooide vooropleiding en een aantal individuele achtergrondkenmerken van de schoolverlaters.

In dit hoofdstuk worden de onderzochte EAO-schoolverlaters achtereenvolgens beschreven aan de hand van een aantal achtergrondkenmerken. Het gaat hierbij om een drietal persoonsgerelateerde kenmerken en een aantal kenmerken van de EAQ-opleiding en Yan fe Yonrnn|fiding

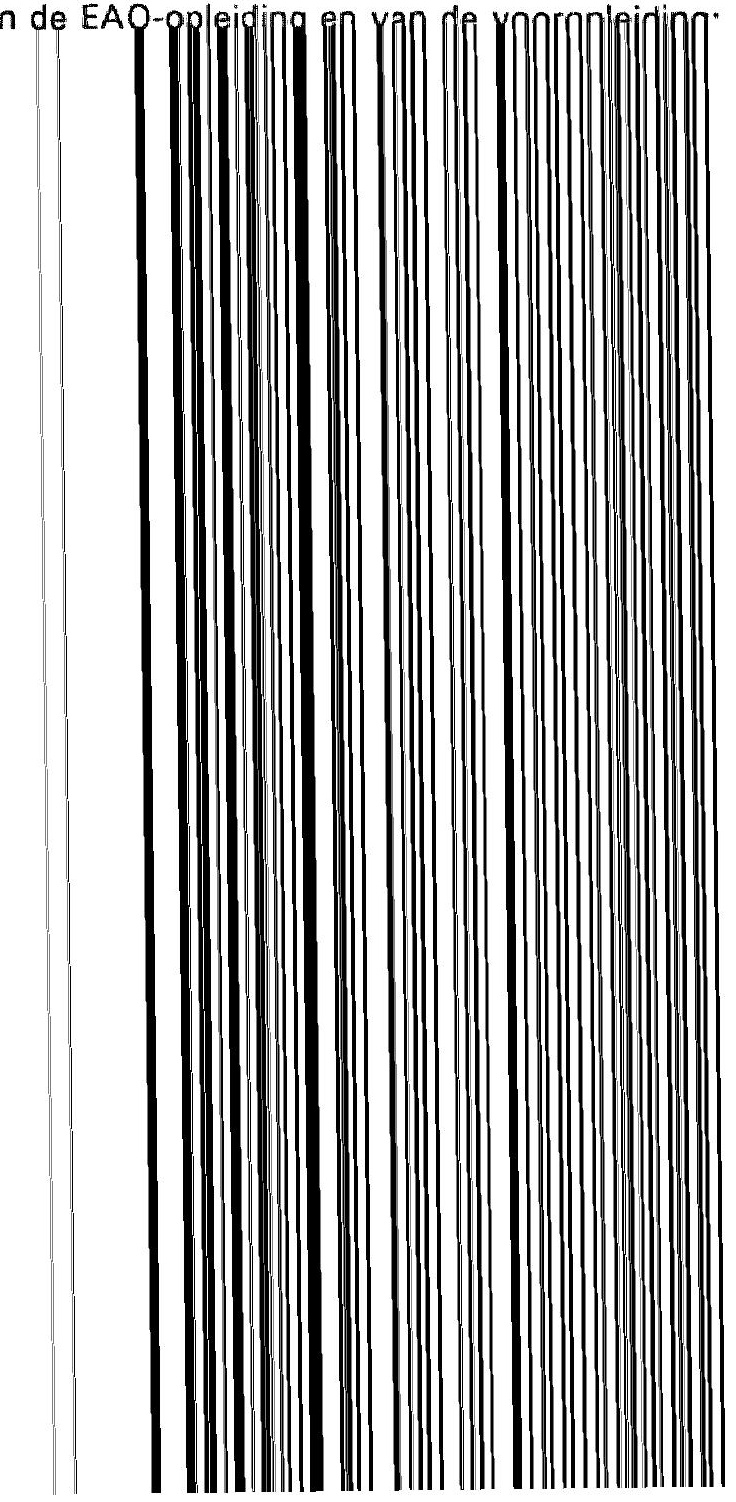




\section{PERSOONSKENMERKEN EN GENOTEN OPLEIDING}

\subsection{Inleiding}

De aan de EAO-school gevolgde vakrichting alsmede het resultaat waarmee men deze opleiding heeft verlaten, vormt de eerste invalshoek van waaruit de arbeidsmarktbestemming inzichtelijk kan worden gemaakt. De verklaring van eventuele verschillen in arbeidsmarktbestemming die zich beperkt tot het aspect vakrichting en opleidingsresultaat is onvolledig, omdat de mate van succes op de arbeidsmarkt ook kan afhangen van extra kwalificaties in de vorm van een voltooide vooropleiding en een aantal individuele achtergrondkenmerken van de schoolverlaters.

In dit hoofdstuk worden de onderzochte EAO-schoolverlaters achtereenvolgens beschreven aan de hand van een aantal achtergrondkenmerken. Het gaat hierbij om een drietal persoonsgerelateerde kenmerken en een aantal kenmerken van de EAQ-opleiding en Yan fe Yonrnn|fiding

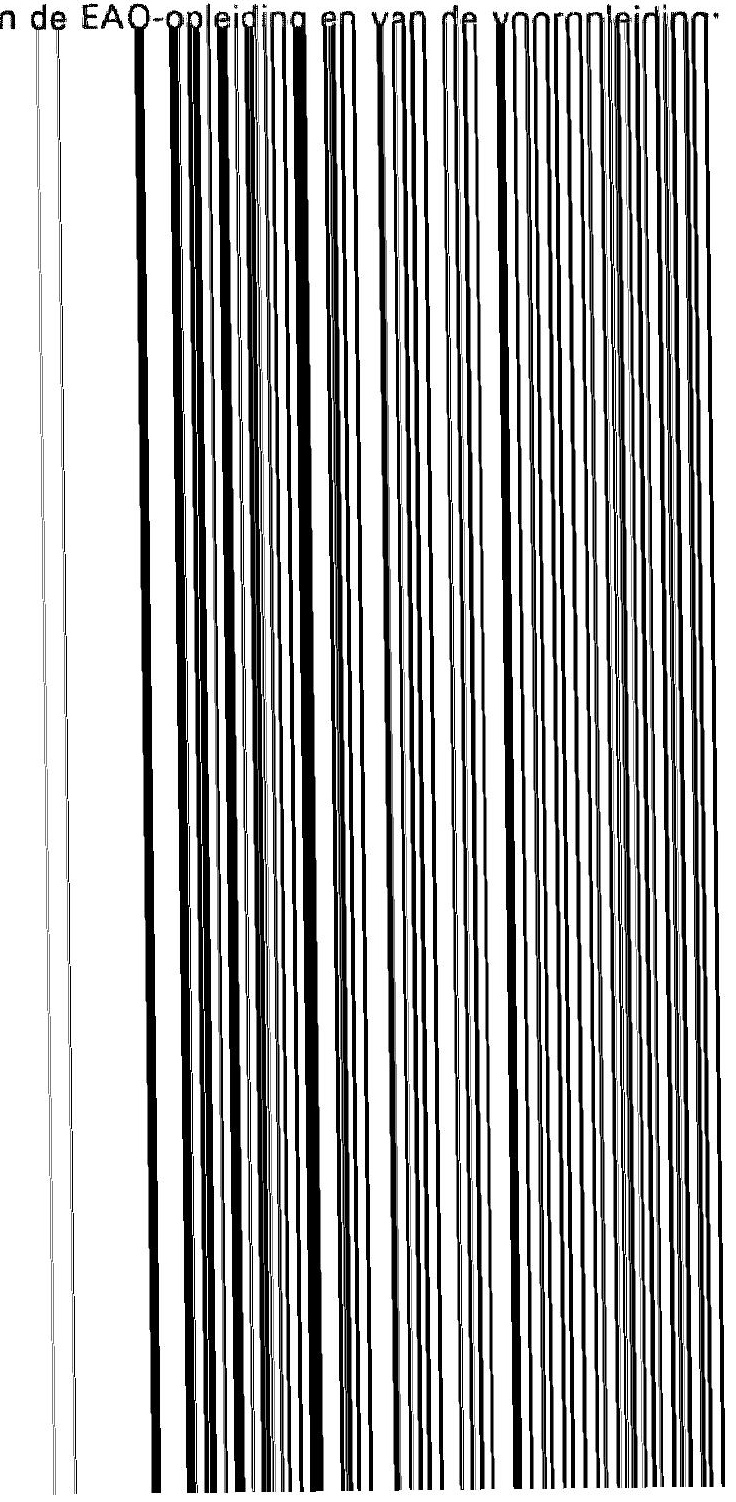




\section{PERSOONSKENMERKEN EN GENOTEN OPLEIDING}

\subsection{Inleiding}

De aan de EAO-school gevolgde vakrichting alsmede het resultaat waarmee men deze opleiding heeft verlaten, vormt de eerste invalshoek van waaruit de arbeidsmarktbestemming inzichtelijk kan worden gemaakt. De verklaring van eventuele verschillen in arbeidsmarktbestemming die zich beperkt tot het aspect vakrichting en opleidingsresultaat is onvolledig, omdat de mate van succes op de arbeidsmarkt ook kan afhangen van extra kwalificaties in de vorm van een voltooide vooropleiding en een aantal individuele achtergrondkenmerken van de schoolverlaters.

In dit hoofdstuk worden de onderzochte EAO-schoolverlaters achtereenvolgens beschreven aan de hand van een aantal achtergrondkenmerken. Het gaat hierbij om een drietal persoonsgerelateerde kenmerken en een aantal kenmerken van de EAQ-opleiding en Yan fe Yonrnn|fiding

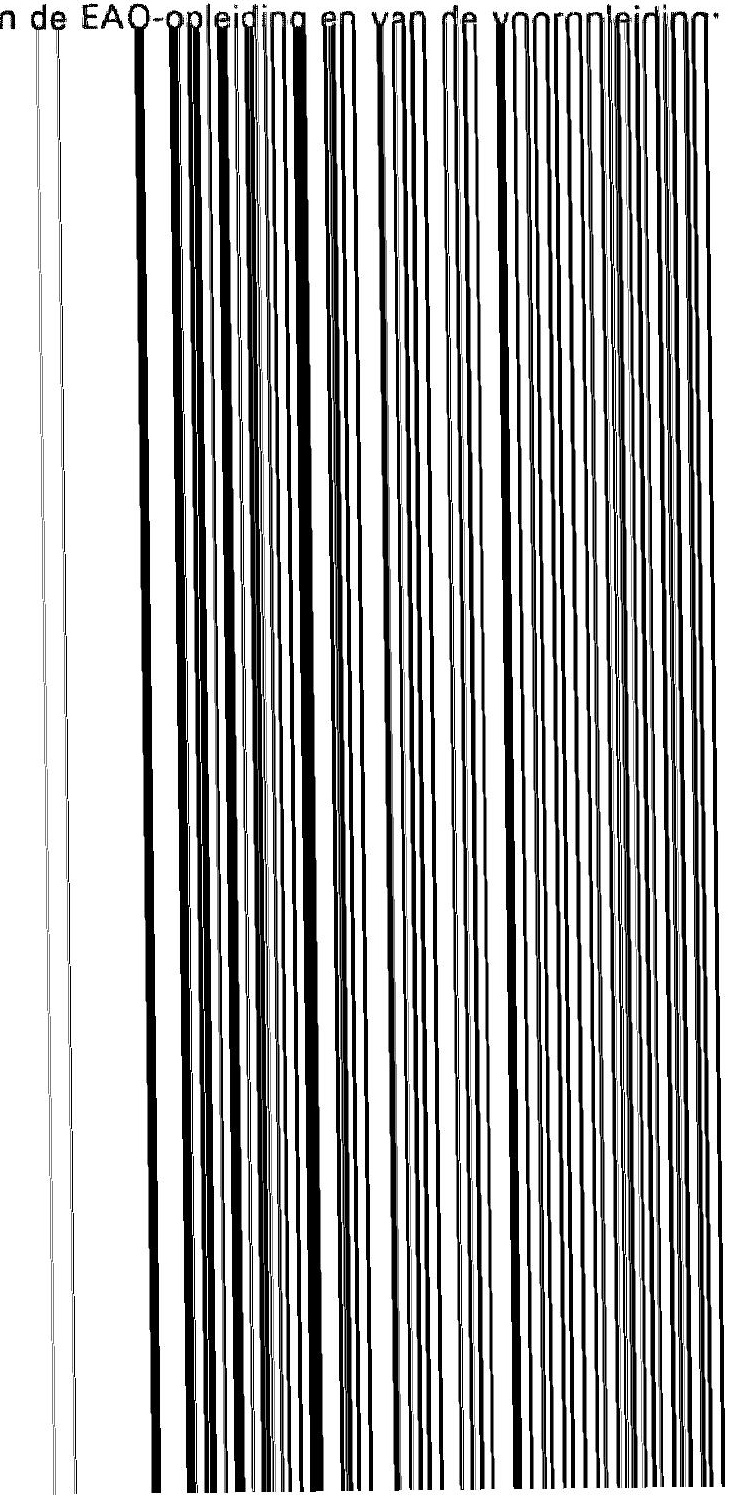




\section{PERSOONSKENMERKEN EN GENOTEN OPLEIDING}

\subsection{Inleiding}

De aan de EAO-school gevolgde vakrichting alsmede het resultaat waarmee men deze opleiding heeft verlaten, vormt de eerste invalshoek van waaruit de arbeidsmarktbestemming inzichtelijk kan worden gemaakt. De verklaring van eventuele verschillen in arbeidsmarktbestemming die zich beperkt tot het aspect vakrichting en opleidingsresultaat is onvolledig, omdat de mate van succes op de arbeidsmarkt ook kan afhangen van extra kwalificaties in de vorm van een voltooide vooropleiding en een aantal individuele achtergrondkenmerken van de schoolverlaters.

In dit hoofdstuk worden de onderzochte EAO-schoolverlaters achtereenvolgens beschreven aan de hand van een aantal achtergrondkenmerken. Het gaat hierbij om een drietal persoonsgerelateerde kenmerken en een aantal kenmerken van de EAQ-opleiding en Yan fe Yonrnn|fiding

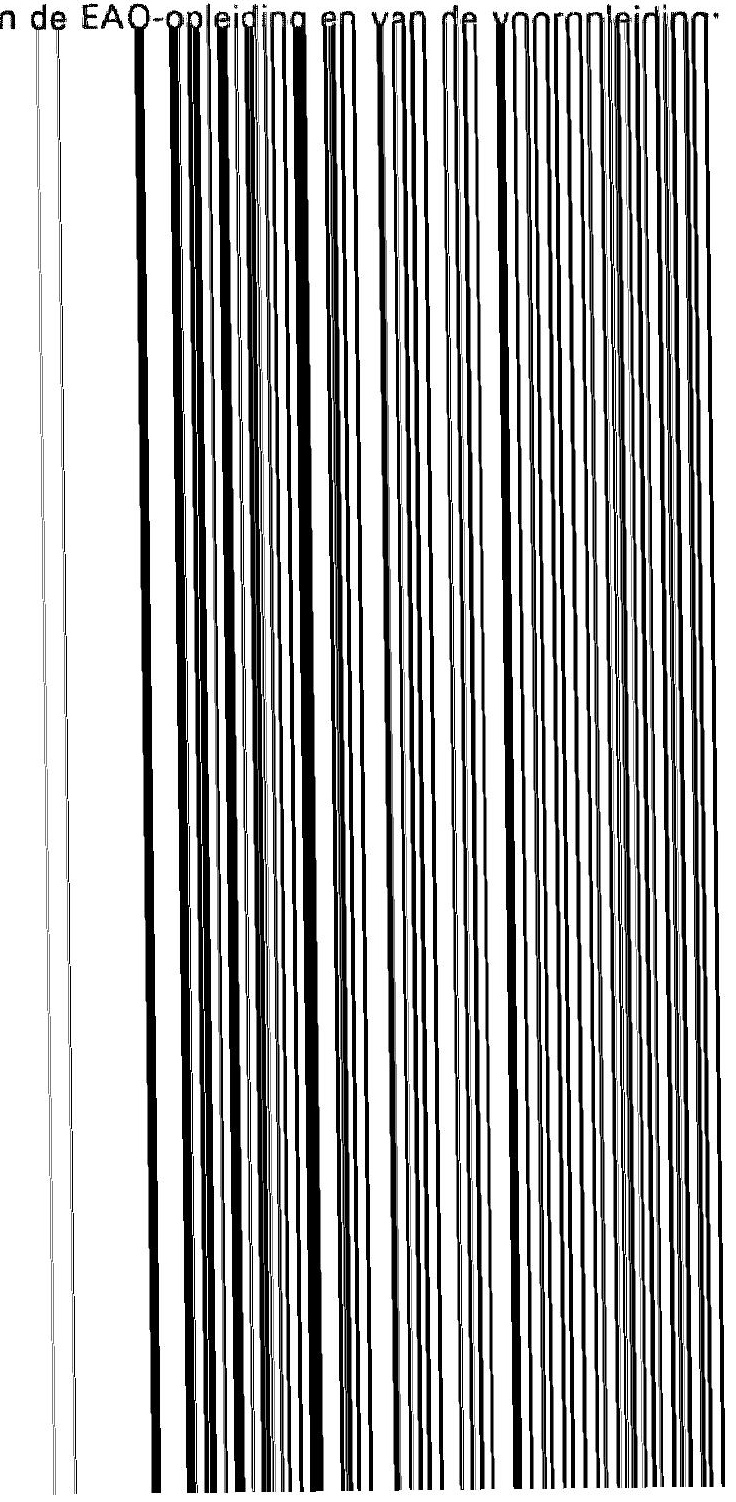




\section{PERSOONSKENMERKEN EN GENOTEN OPLEIDING}

\subsection{Inleiding}

De aan de EAO-school gevolgde vakrichting alsmede het resultaat waarmee men deze opleiding heeft verlaten, vormt de eerste invalshoek van waaruit de arbeidsmarktbestemming inzichtelijk kan worden gemaakt. De verklaring van eventuele verschillen in arbeidsmarktbestemming die zich beperkt tot het aspect vakrichting en opleidingsresultaat is onvolledig, omdat de mate van succes op de arbeidsmarkt ook kan afhangen van extra kwalificaties in de vorm van een voltooide vooropleiding en een aantal individuele achtergrondkenmerken van de schoolverlaters.

In dit hoofdstuk worden de onderzochte EAO-schoolverlaters achtereenvolgens beschreven aan de hand van een aantal achtergrondkenmerken. Het gaat hierbij om een drietal persoonsgerelateerde kenmerken en een aantal kenmerken van de EAQ-opleiding en Yan fe Yonrnn|fiding

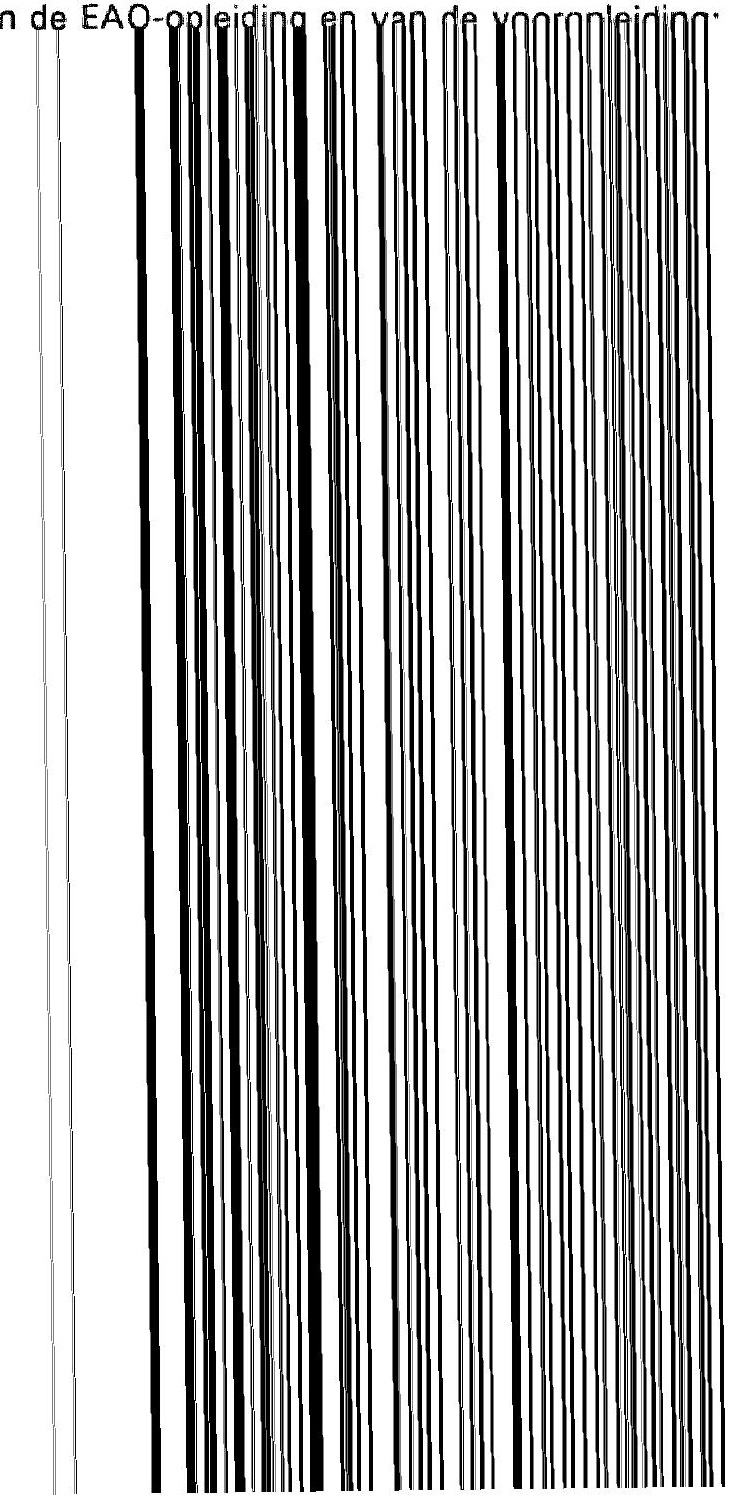




\section{PERSOONSKENMERKEN EN GENOTEN OPLEIDING}

\subsection{Inleiding}

De aan de EAO-school gevolgde vakrichting alsmede het resultaat waarmee men deze opleiding heeft verlaten, vormt de eerste invalshoek van waaruit de arbeidsmarktbestemming inzichtelijk kan worden gemaakt. De verklaring van eventuele verschillen in arbeidsmarktbestemming die zich beperkt tot het aspect vakrichting en opleidingsresultaat is onvolledig, omdat de mate van succes op de arbeidsmarkt ook kan afhangen van extra kwalificaties in de vorm van een voltooide vooropleiding en een aantal individuele achtergrondkenmerken van de schoolverlaters.

In dit hoofdstuk worden de onderzochte EAO-schoolverlaters achtereenvolgens beschreven aan de hand van een aantal achtergrondkenmerken. Het gaat hierbij om een drietal persoonsgerelateerde kenmerken en een aantal kenmerken van de EAQ-opleiding en Yan fe Yonrnn|fiding

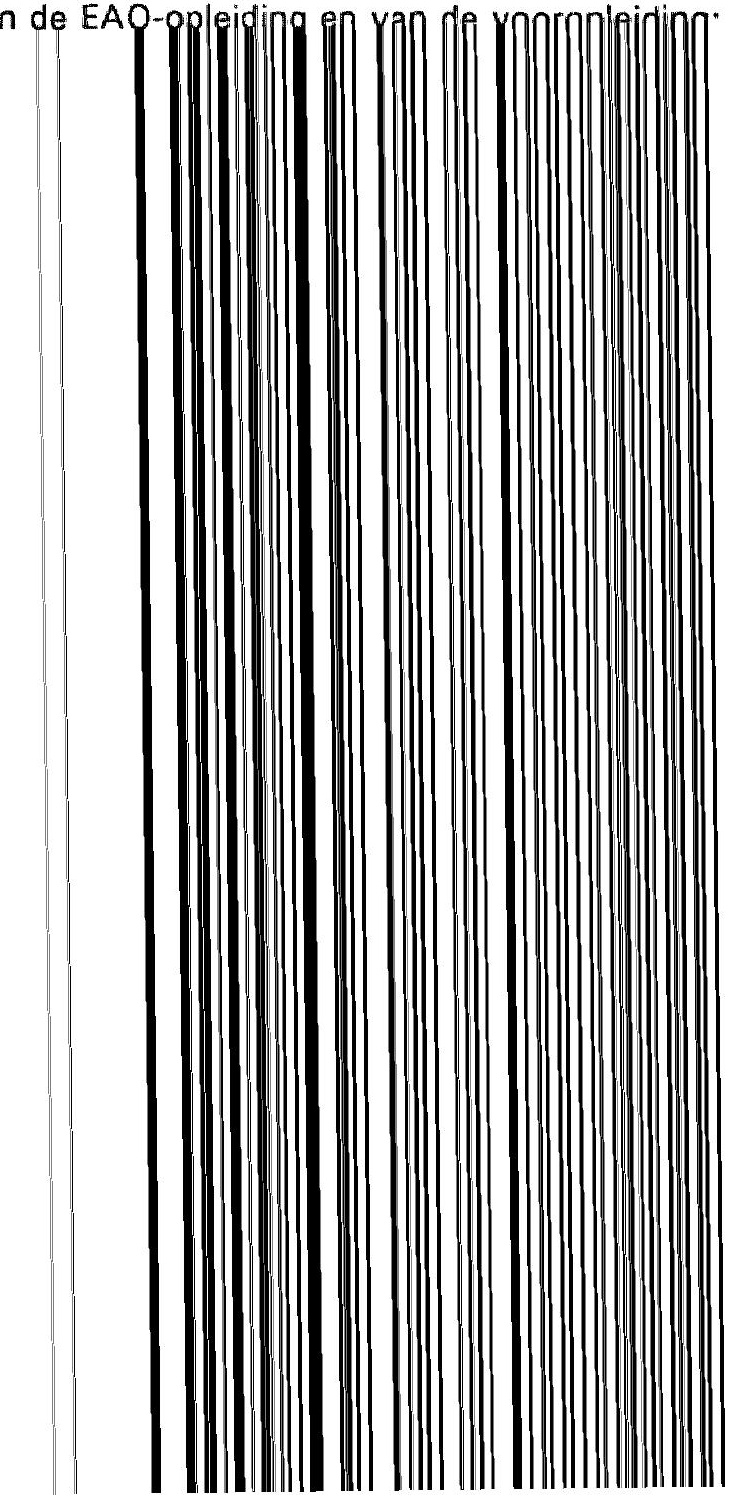




\section{PERSOONSKENMERKEN EN GENOTEN OPLEIDING}

\subsection{Inleiding}

De aan de EAO-school gevolgde vakrichting alsmede het resultaat waarmee men deze opleiding heeft verlaten, vormt de eerste invalshoek van waaruit de arbeidsmarktbestemming inzichtelijk kan worden gemaakt. De verklaring van eventuele verschillen in arbeidsmarktbestemming die zich beperkt tot het aspect vakrichting en opleidingsresultaat is onvolledig, omdat de mate van succes op de arbeidsmarkt ook kan afhangen van extra kwalificaties in de vorm van een voltooide vooropleiding en een aantal individuele achtergrondkenmerken van de schoolverlaters.

In dit hoofdstuk worden de onderzochte EAO-schoolverlaters achtereenvolgens beschreven aan de hand van een aantal achtergrondkenmerken. Het gaat hierbij om een drietal persoonsgerelateerde kenmerken en een aantal kenmerken van de EAQ-opleiding en Yan fe Yonrnn|fiding

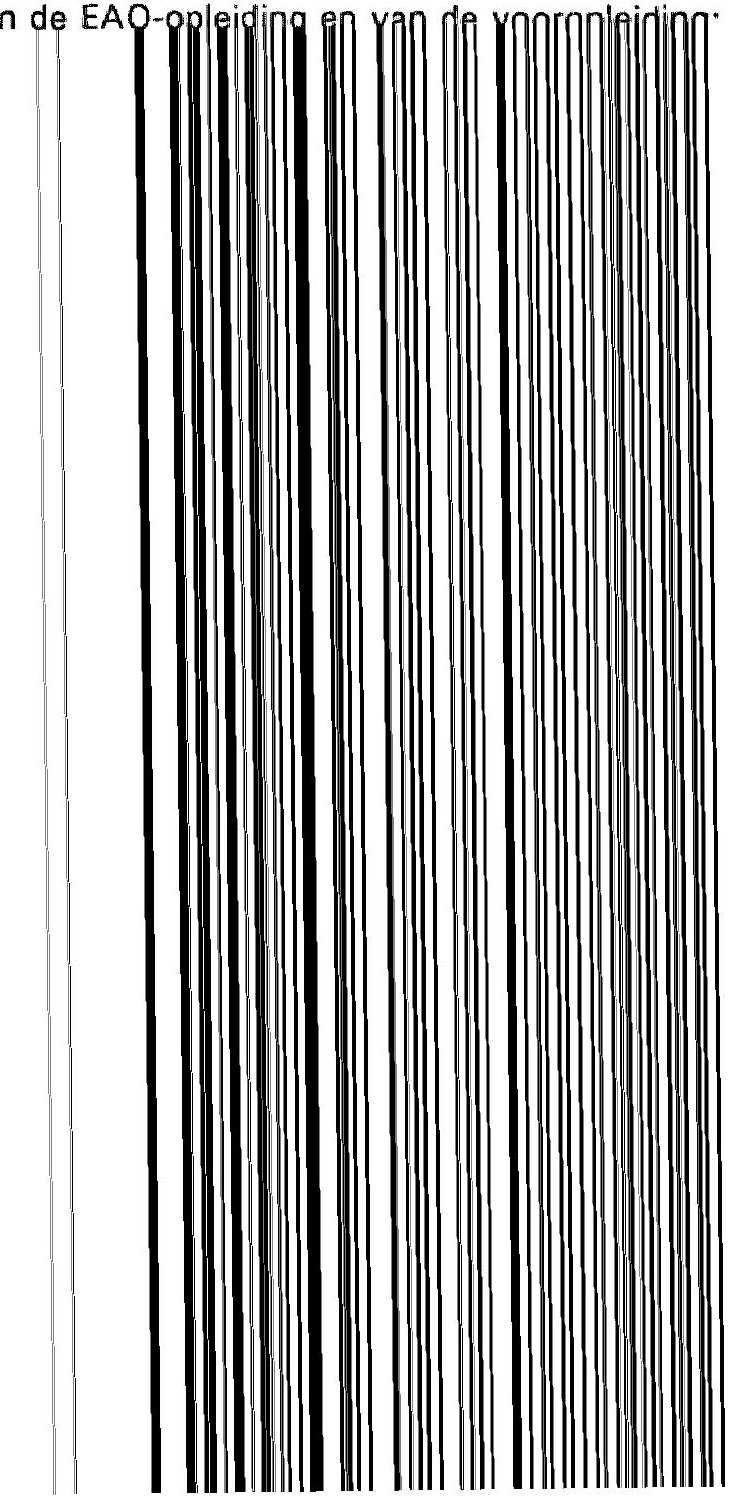




\section{PERSOONSKENMERKEN EN GENOTEN OPLEIDING}

\subsection{Inleiding}

De aan de EAO-school gevolgde vakrichting alsmede het resultaat waarmee men deze opleiding heeft verlaten, vormt de eerste invalshoek van waaruit de arbeidsmarktbestemming inzichtelijk kan worden gemaakt. De verklaring van eventuele verschillen in arbeidsmarktbestemming die zich beperkt tot het aspect vakrichting en opleidingsresultaat is onvolledig, omdat de mate van succes op de arbeidsmarkt ook kan afhangen van extra kwalificaties in de vorm van een voltooide vooropleiding en een aantal individuele achtergrondkenmerken van de schoolverlaters.

In dit hoofdstuk worden de onderzochte EAO-schoolverlaters achtereenvolgens beschreven aan de hand van een aantal achtergrondkenmerken. Het gaat hierbij om een drietal persoonsgerelateerde kenmerken en een aantal kenmerken van de EAQ-opleiding en Yan fe Yonrnn|fiding

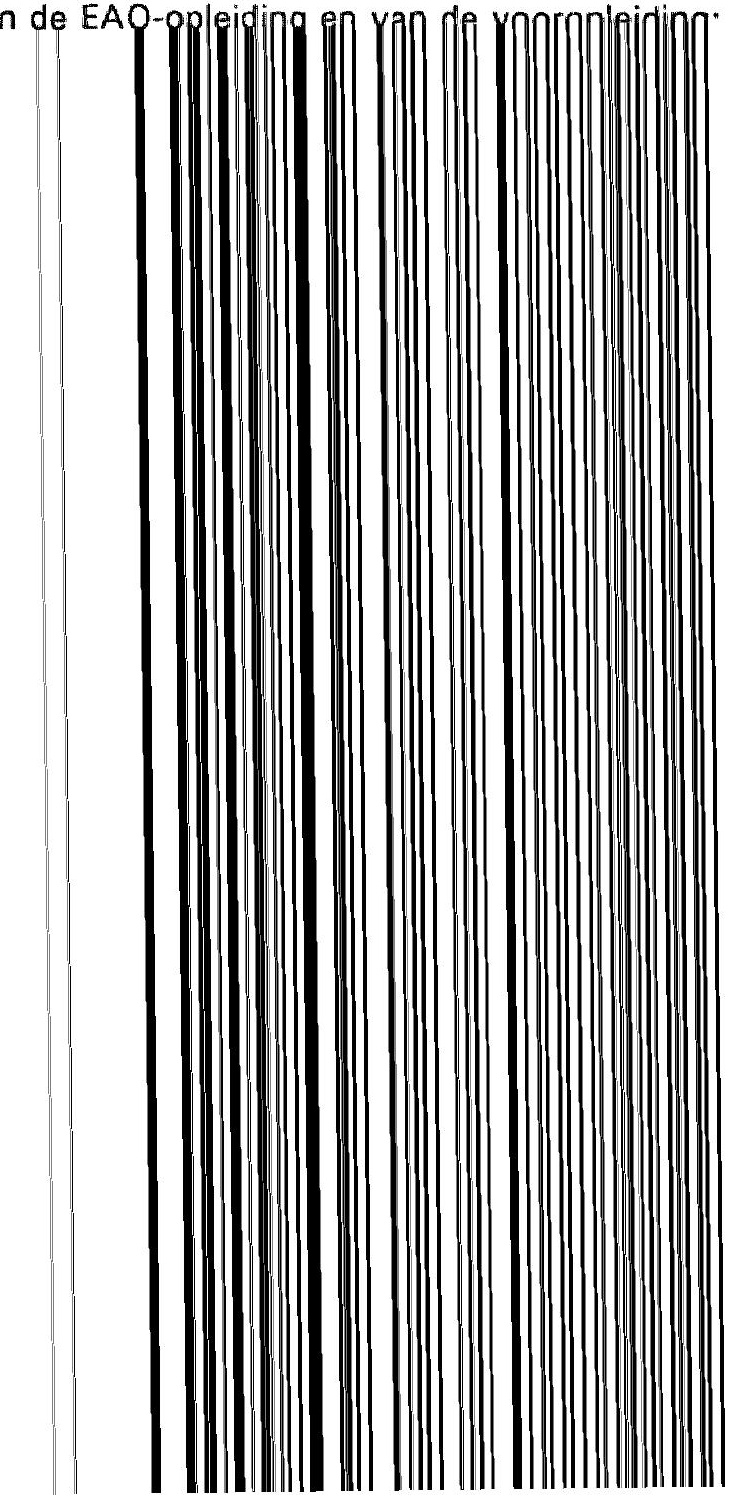




\section{PERSOONSKENMERKEN EN GENOTEN OPLEIDING}

\subsection{Inleiding}

De aan de EAO-school gevolgde vakrichting alsmede het resultaat waarmee men deze opleiding heeft verlaten, vormt de eerste invalshoek van waaruit de arbeidsmarktbestemming inzichtelijk kan worden gemaakt. De verklaring van eventuele verschillen in arbeidsmarktbestemming die zich beperkt tot het aspect vakrichting en opleidingsresultaat is onvolledig, omdat de mate van succes op de arbeidsmarkt ook kan afhangen van extra kwalificaties in de vorm van een voltooide vooropleiding en een aantal individuele achtergrondkenmerken van de schoolverlaters.

In dit hoofdstuk worden de onderzochte EAO-schoolverlaters achtereenvolgens beschreven aan de hand van een aantal achtergrondkenmerken. Het gaat hierbij om een drietal persoonsgerelateerde kenmerken en een aantal kenmerken van de EAQ-opleiding en Yan fe Yonrnn|fiding

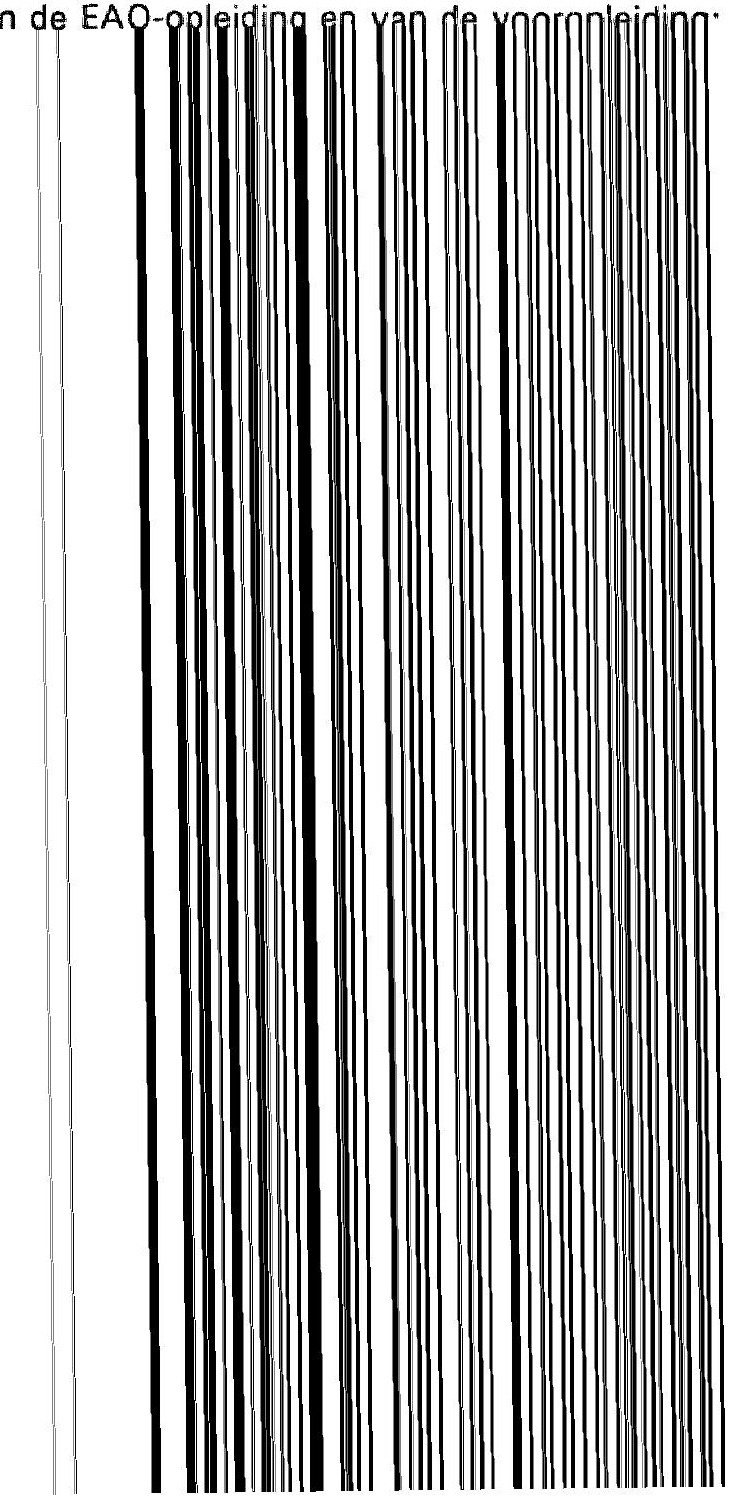




\section{PERSOONSKENMERKEN EN GENOTEN OPLEIDING}

\subsection{Inleiding}

De aan de EAO-school gevolgde vakrichting alsmede het resultaat waarmee men deze opleiding heeft verlaten, vormt de eerste invalshoek van waaruit de arbeidsmarktbestemming inzichtelijk kan worden gemaakt. De verklaring van eventuele verschillen in arbeidsmarktbestemming die zich beperkt tot het aspect vakrichting en opleidingsresultaat is onvolledig, omdat de mate van succes op de arbeidsmarkt ook kan afhangen van extra kwalificaties in de vorm van een voltooide vooropleiding en een aantal individuele achtergrondkenmerken van de schoolverlaters.

In dit hoofdstuk worden de onderzochte EAO-schoolverlaters achtereenvolgens beschreven aan de hand van een aantal achtergrondkenmerken. Het gaat hierbij om een drietal persoonsgerelateerde kenmerken en een aantal kenmerken van de EAQ-opleiding en Yan fe Yonrnn|fiding

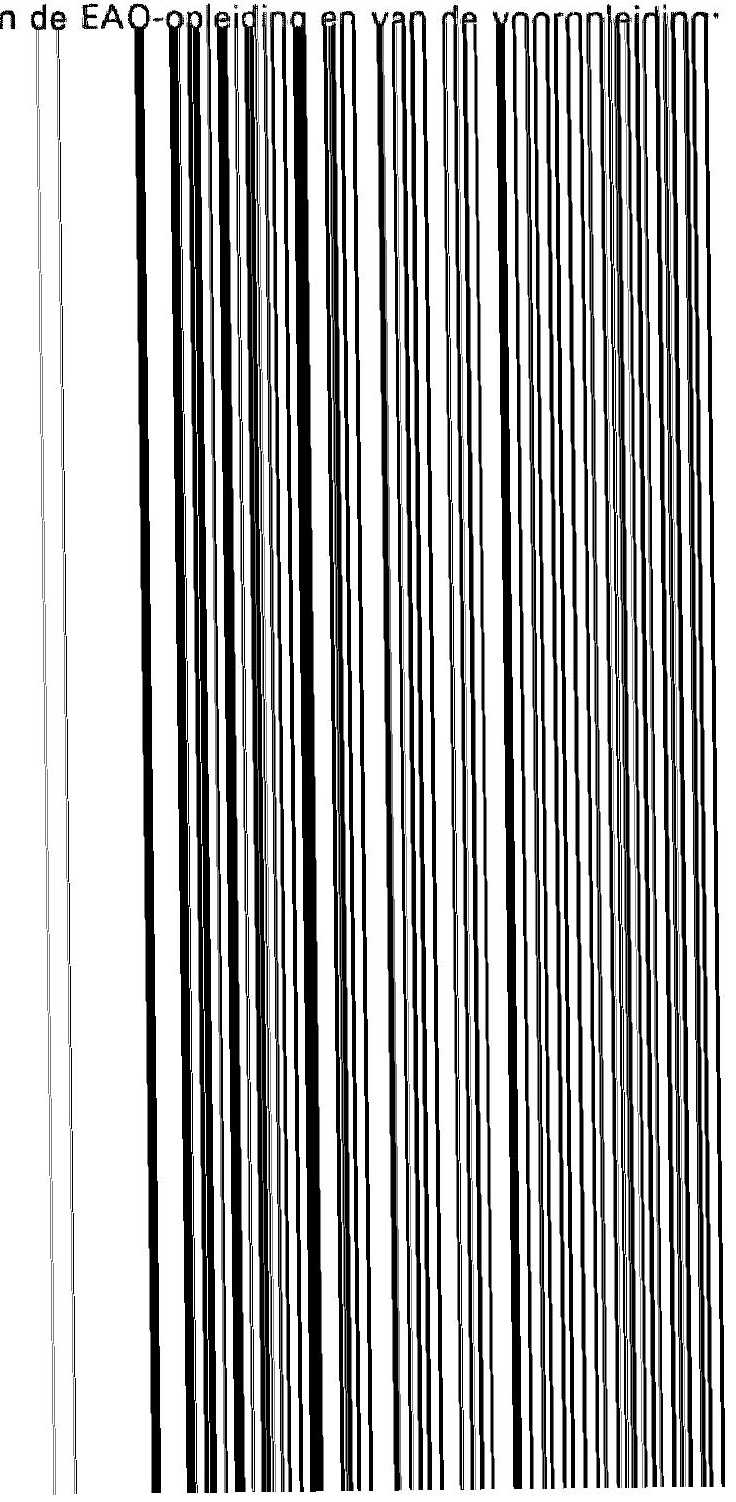




\section{PERSOONSKENMERKEN EN GENOTEN OPLEIDING}

\subsection{Inleiding}

De aan de EAO-school gevolgde vakrichting alsmede het resultaat waarmee men deze opleiding heeft verlaten, vormt de eerste invalshoek van waaruit de arbeidsmarktbestemming inzichtelijk kan worden gemaakt. De verklaring van eventuele verschillen in arbeidsmarktbestemming die zich beperkt tot het aspect vakrichting en opleidingsresultaat is onvolledig, omdat de mate van succes op de arbeidsmarkt ook kan afhangen van extra kwalificaties in de vorm van een voltooide vooropleiding en een aantal individuele achtergrondkenmerken van de schoolverlaters.

In dit hoofdstuk worden de onderzochte EAO-schoolverlaters achtereenvolgens beschreven aan de hand van een aantal achtergrondkenmerken. Het gaat hierbij om een drietal persoonsgerelateerde kenmerken en een aantal kenmerken van de EAQ-opleiding en Yan fe Yonrnn|fiding

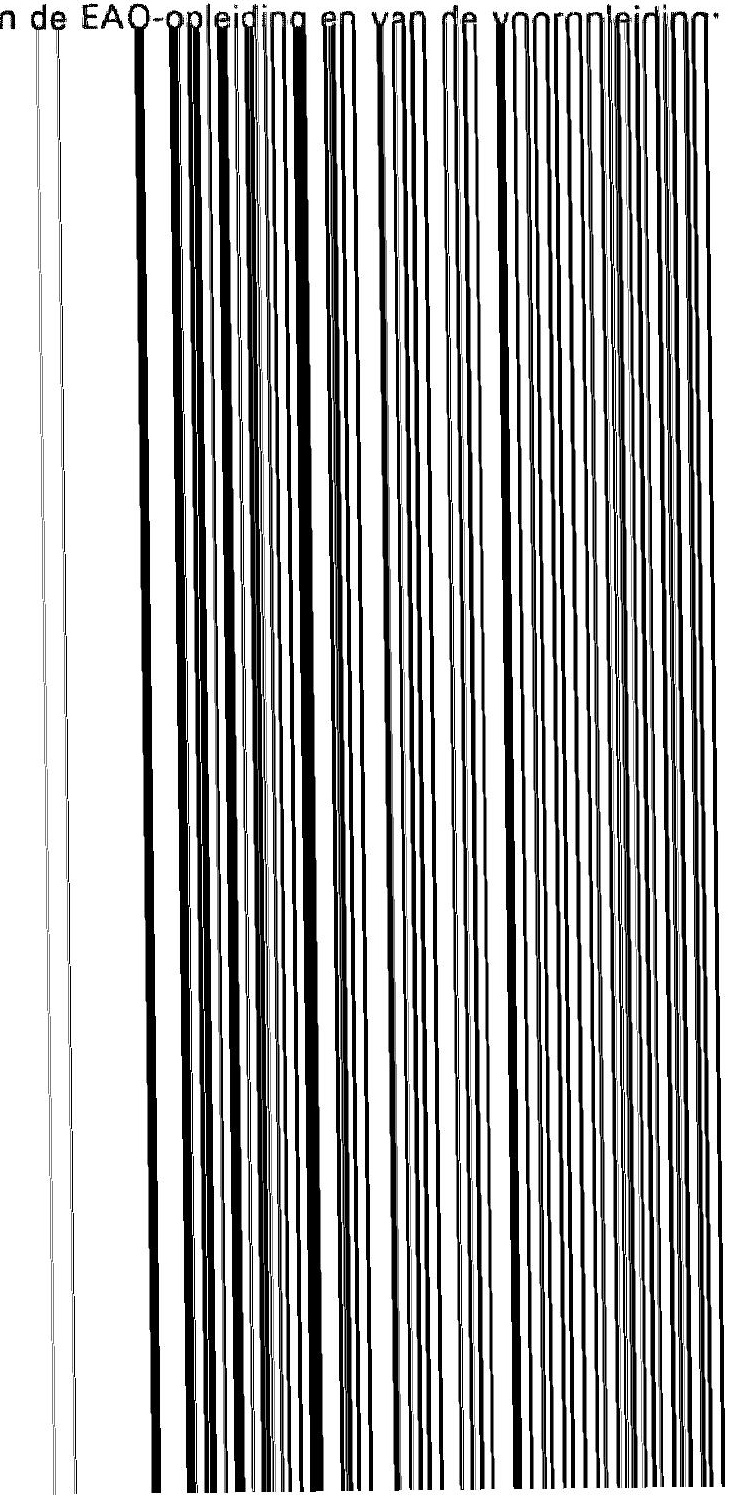




\section{PERSOONSKENMERKEN EN GENOTEN OPLEIDING}

\subsection{Inleiding}

De aan de EAO-school gevolgde vakrichting alsmede het resultaat waarmee men deze opleiding heeft verlaten, vormt de eerste invalshoek van waaruit de arbeidsmarktbestemming inzichtelijk kan worden gemaakt. De verklaring van eventuele verschillen in arbeidsmarktbestemming die zich beperkt tot het aspect vakrichting en opleidingsresultaat is onvolledig, omdat de mate van succes op de arbeidsmarkt ook kan afhangen van extra kwalificaties in de vorm van een voltooide vooropleiding en een aantal individuele achtergrondkenmerken van de schoolverlaters.

In dit hoofdstuk worden de onderzochte EAO-schoolverlaters achtereenvolgens beschreven aan de hand van een aantal achtergrondkenmerken. Het gaat hierbij om een drietal persoonsgerelateerde kenmerken en een aantal kenmerken van de EAQ-opleiding en Yan fe Yonrnn|fiding

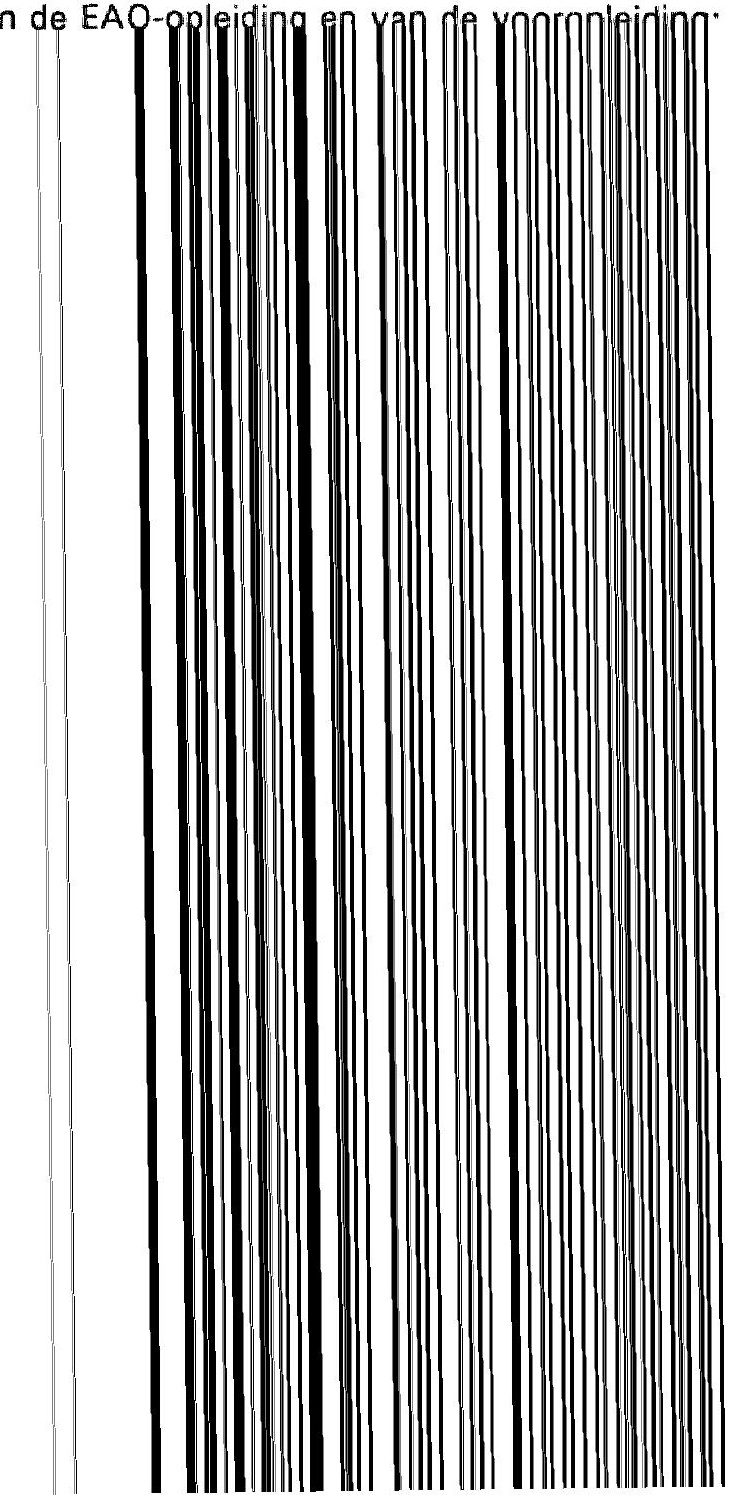




\section{PERSOONSKENMERKEN EN GENOTEN OPLEIDING}

\subsection{Inleiding}

De aan de EAO-school gevolgde vakrichting alsmede het resultaat waarmee men deze opleiding heeft verlaten, vormt de eerste invalshoek van waaruit de arbeidsmarktbestemming inzichtelijk kan worden gemaakt. De verklaring van eventuele verschillen in arbeidsmarktbestemming die zich beperkt tot het aspect vakrichting en opleidingsresultaat is onvolledig, omdat de mate van succes op de arbeidsmarkt ook kan afhangen van extra kwalificaties in de vorm van een voltooide vooropleiding en een aantal individuele achtergrondkenmerken van de schoolverlaters.

In dit hoofdstuk worden de onderzochte EAO-schoolverlaters achtereenvolgens beschreven aan de hand van een aantal achtergrondkenmerken. Het gaat hierbij om een drietal persoonsgerelateerde kenmerken en een aantal kenmerken van de EAQ-opleiding en Yan fe Yonrnn|fiding

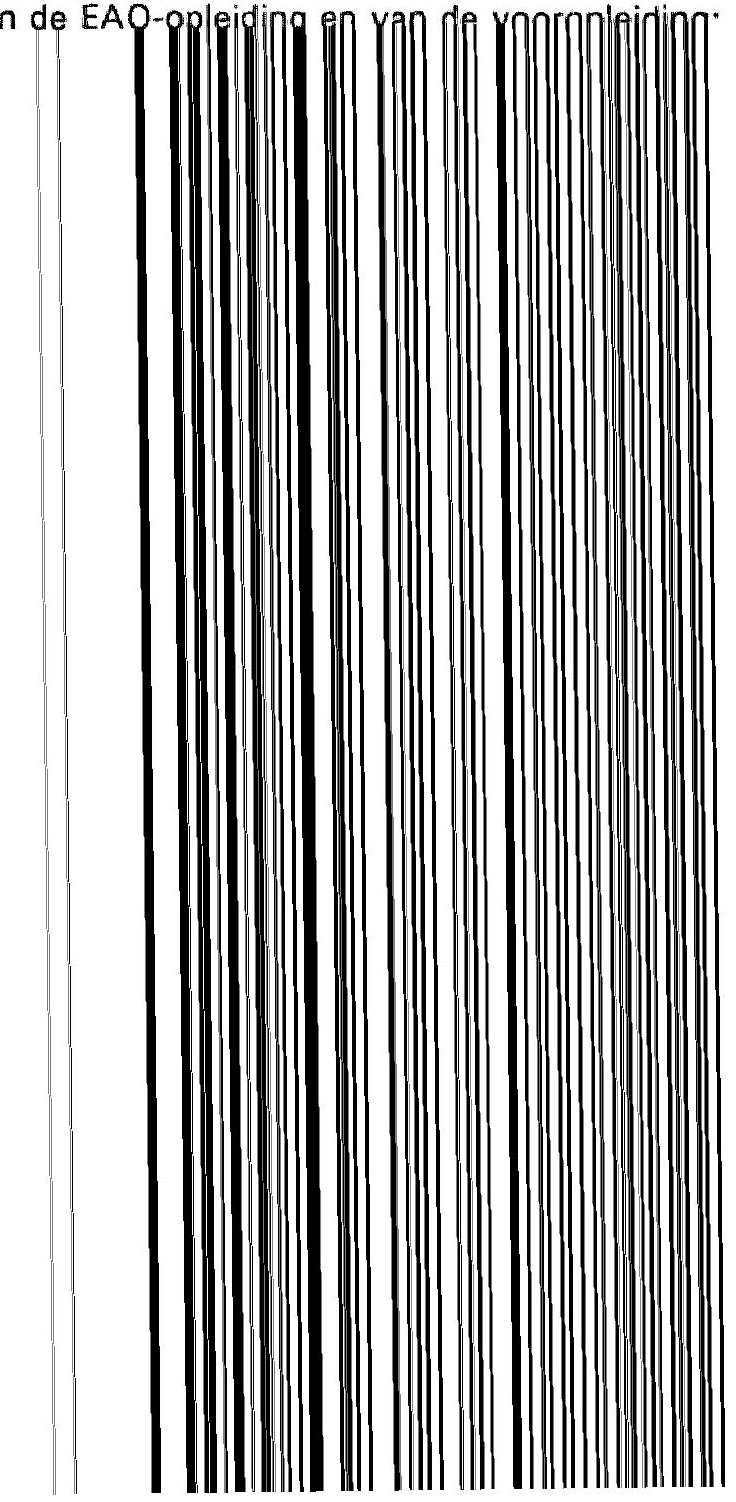




\section{PERSOONSKENMERKEN EN GENOTEN OPLEIDING}

\subsection{Inleiding}

De aan de EAO-school gevolgde vakrichting alsmede het resultaat waarmee men deze opleiding heeft verlaten, vormt de eerste invalshoek van waaruit de arbeidsmarktbestemming inzichtelijk kan worden gemaakt. De verklaring van eventuele verschillen in arbeidsmarktbestemming die zich beperkt tot het aspect vakrichting en opleidingsresultaat is onvolledig, omdat de mate van succes op de arbeidsmarkt ook kan afhangen van extra kwalificaties in de vorm van een voltooide vooropleiding en een aantal individuele achtergrondkenmerken van de schoolverlaters.

In dit hoofdstuk worden de onderzochte EAO-schoolverlaters achtereenvolgens beschreven aan de hand van een aantal achtergrondkenmerken. Het gaat hierbij om een drietal persoonsgerelateerde kenmerken en een aantal kenmerken van de EAQ-opleiding en Yan fe Yonrnn|fiding

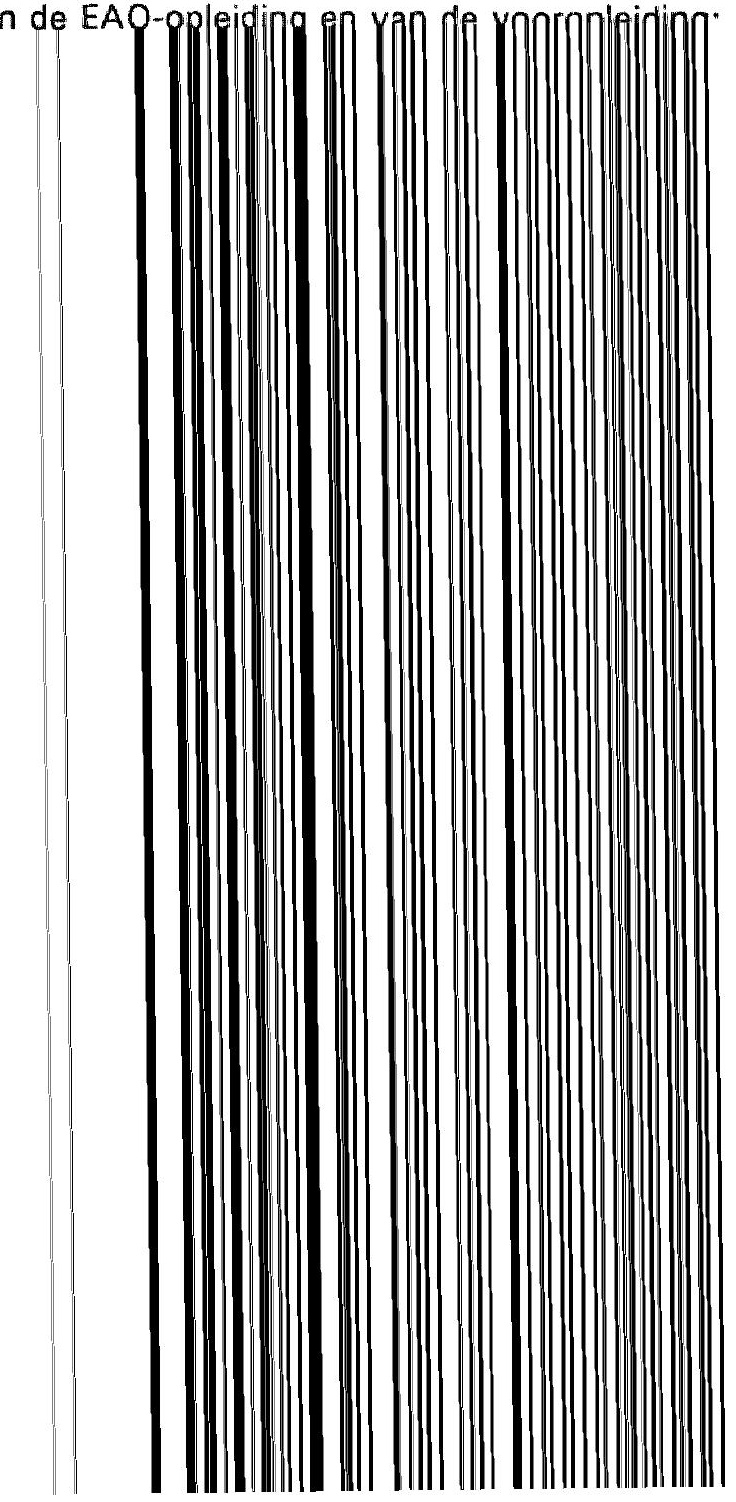




\section{PERSOONSKENMERKEN EN GENOTEN OPLEIDING}

\subsection{Inleiding}

De aan de EAO-school gevolgde vakrichting alsmede het resultaat waarmee men deze opleiding heeft verlaten, vormt de eerste invalshoek van waaruit de arbeidsmarktbestemming inzichtelijk kan worden gemaakt. De verklaring van eventuele verschillen in arbeidsmarktbestemming die zich beperkt tot het aspect vakrichting en opleidingsresultaat is onvolledig, omdat de mate van succes op de arbeidsmarkt ook kan afhangen van extra kwalificaties in de vorm van een voltooide vooropleiding en een aantal individuele achtergrondkenmerken van de schoolverlaters.

In dit hoofdstuk worden de onderzochte EAO-schoolverlaters achtereenvolgens beschreven aan de hand van een aantal achtergrondkenmerken. Het gaat hierbij om een drietal persoonsgerelateerde kenmerken en een aantal kenmerken van de EAQ-opleiding en Yan fe Yonrnn|fiding

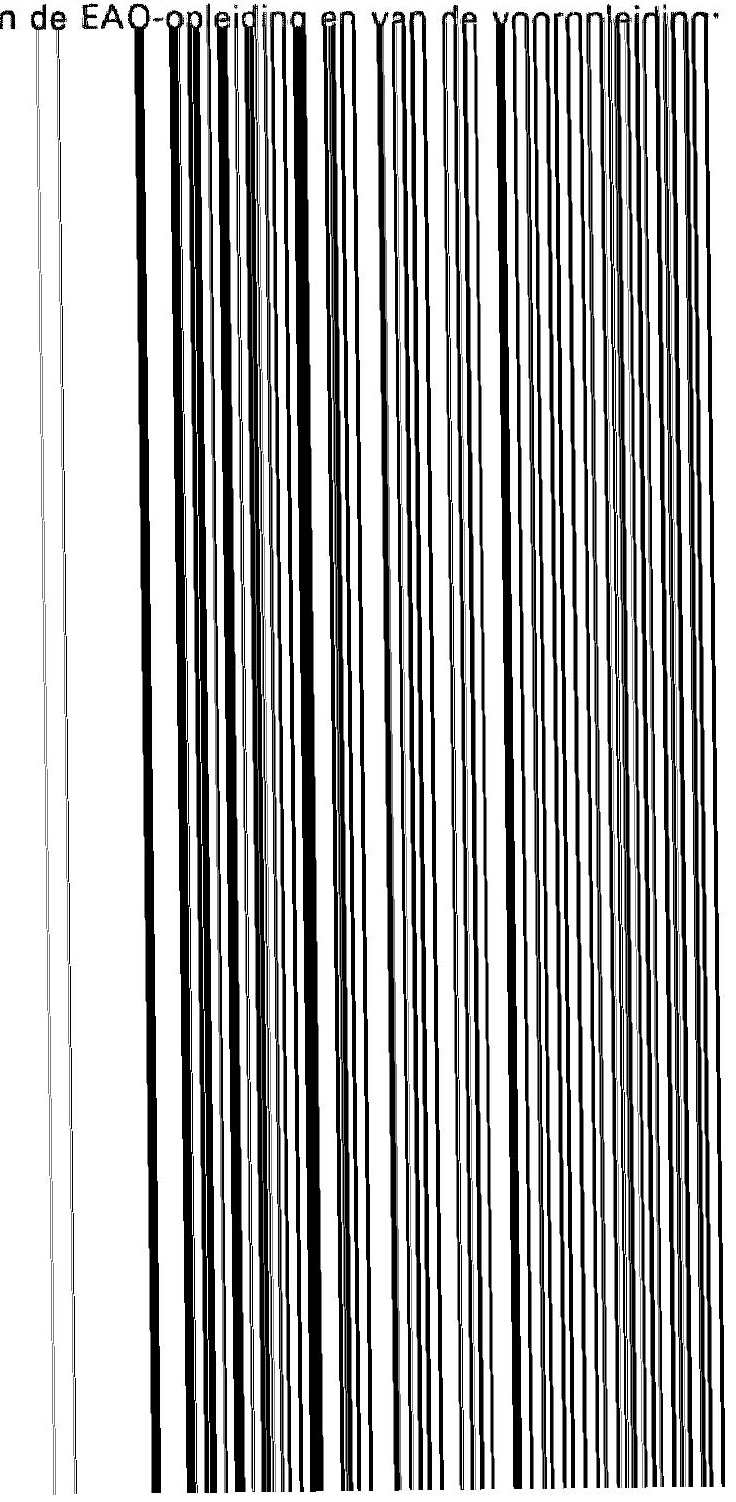




\section{PERSOONSKENMERKEN EN GENOTEN OPLEIDING}

\subsection{Inleiding}

De aan de EAO-school gevolgde vakrichting alsmede het resultaat waarmee men deze opleiding heeft verlaten, vormt de eerste invalshoek van waaruit de arbeidsmarktbestemming inzichtelijk kan worden gemaakt. De verklaring van eventuele verschillen in arbeidsmarktbestemming die zich beperkt tot het aspect vakrichting en opleidingsresultaat is onvolledig, omdat de mate van succes op de arbeidsmarkt ook kan afhangen van extra kwalificaties in de vorm van een voltooide vooropleiding en een aantal individuele achtergrondkenmerken van de schoolverlaters.

In dit hoofdstuk worden de onderzochte EAO-schoolverlaters achtereenvolgens beschreven aan de hand van een aantal achtergrondkenmerken. Het gaat hierbij om een drietal persoonsgerelateerde kenmerken en een aantal kenmerken van de EAQ-opleiding en Yan fe Yonrnn|fiding

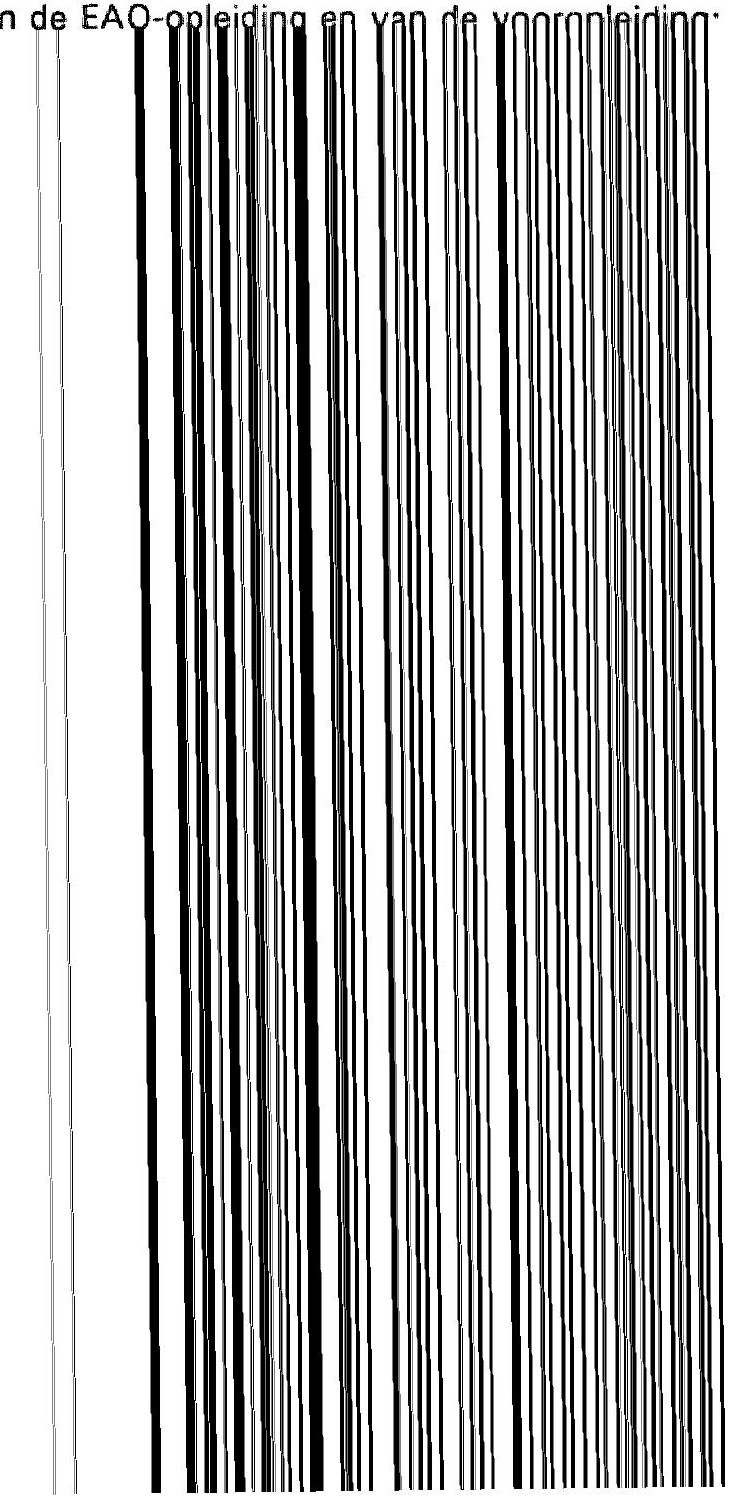




\section{PERSOONSKENMERKEN EN GENOTEN OPLEIDING}

\subsection{Inleiding}

De aan de EAO-school gevolgde vakrichting alsmede het resultaat waarmee men deze opleiding heeft verlaten, vormt de eerste invalshoek van waaruit de arbeidsmarktbestemming inzichtelijk kan worden gemaakt. De verklaring van eventuele verschillen in arbeidsmarktbestemming die zich beperkt tot het aspect vakrichting en opleidingsresultaat is onvolledig, omdat de mate van succes op de arbeidsmarkt ook kan afhangen van extra kwalificaties in de vorm van een voltooide vooropleiding en een aantal individuele achtergrondkenmerken van de schoolverlaters.

In dit hoofdstuk worden de onderzochte EAO-schoolverlaters achtereenvolgens beschreven aan de hand van een aantal achtergrondkenmerken. Het gaat hierbij om een drietal persoonsgerelateerde kenmerken en een aantal kenmerken van de EAQ-opleiding en Yan fe Yonrnn|fiding

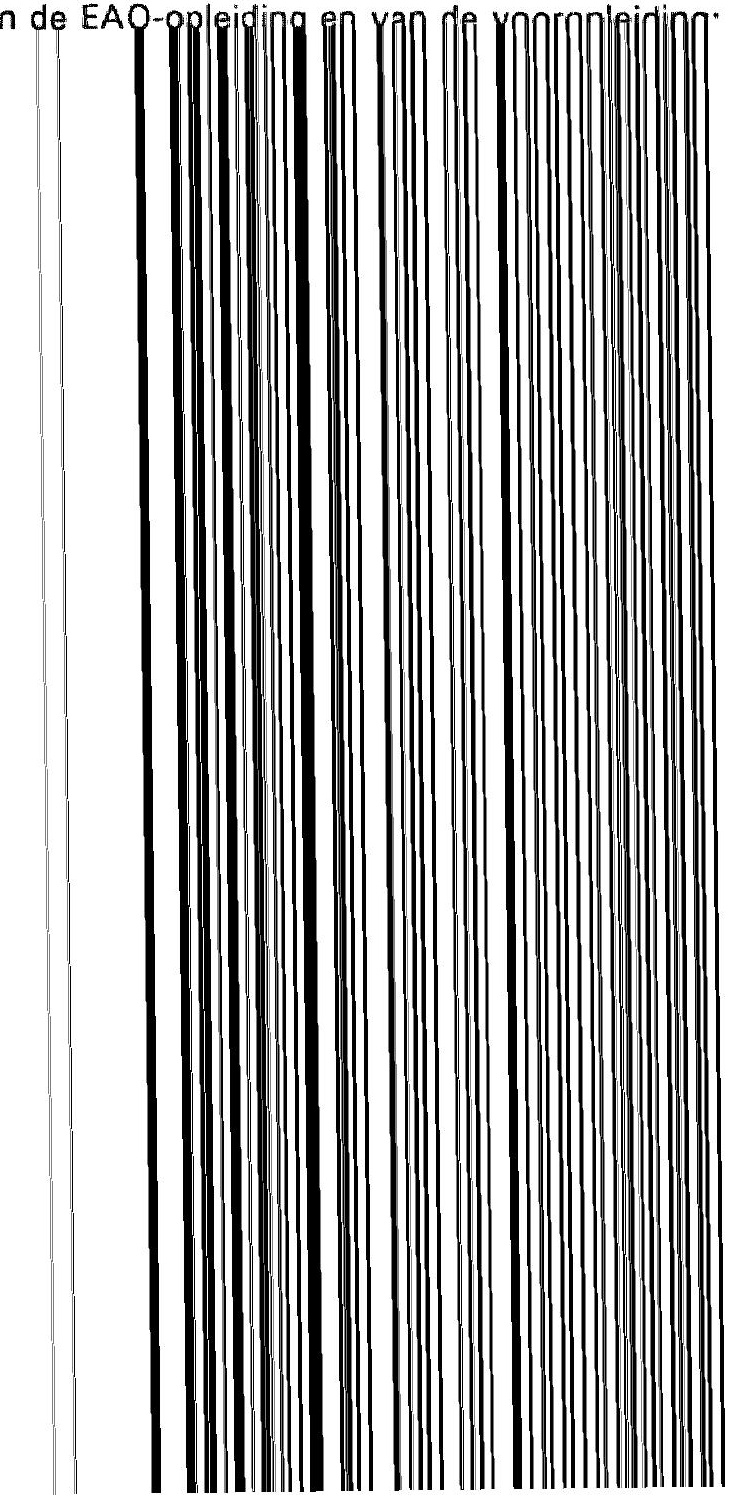




\section{PERSOONSKENMERKEN EN GENOTEN OPLEIDING}

\subsection{Inleiding}

De aan de EAO-school gevolgde vakrichting alsmede het resultaat waarmee men deze opleiding heeft verlaten, vormt de eerste invalshoek van waaruit de arbeidsmarktbestemming inzichtelijk kan worden gemaakt. De verklaring van eventuele verschillen in arbeidsmarktbestemming die zich beperkt tot het aspect vakrichting en opleidingsresultaat is onvolledig, omdat de mate van succes op de arbeidsmarkt ook kan afhangen van extra kwalificaties in de vorm van een voltooide vooropleiding en een aantal individuele achtergrondkenmerken van de schoolverlaters.

In dit hoofdstuk worden de onderzochte EAO-schoolverlaters achtereenvolgens beschreven aan de hand van een aantal achtergrondkenmerken. Het gaat hierbij om een drietal persoonsgerelateerde kenmerken en een aantal kenmerken van de EAQ-opleiding en Yan fe Yonrnn|fiding

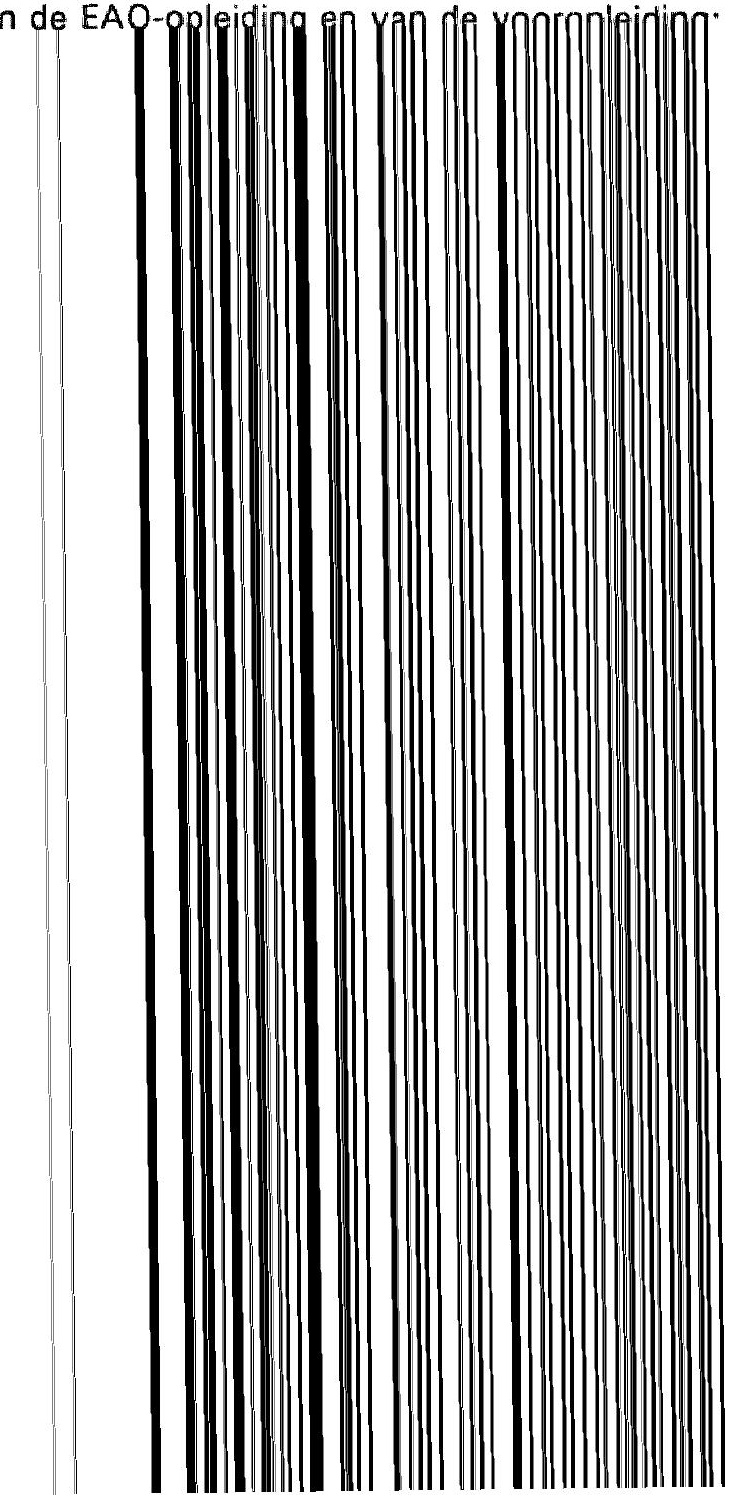




\section{PERSOONSKENMERKEN EN GENOTEN OPLEIDING}

\subsection{Inleiding}

De aan de EAO-school gevolgde vakrichting alsmede het resultaat waarmee men deze opleiding heeft verlaten, vormt de eerste invalshoek van waaruit de arbeidsmarktbestemming inzichtelijk kan worden gemaakt. De verklaring van eventuele verschillen in arbeidsmarktbestemming die zich beperkt tot het aspect vakrichting en opleidingsresultaat is onvolledig, omdat de mate van succes op de arbeidsmarkt ook kan afhangen van extra kwalificaties in de vorm van een voltooide vooropleiding en een aantal individuele achtergrondkenmerken van de schoolverlaters.

In dit hoofdstuk worden de onderzochte EAO-schoolverlaters achtereenvolgens beschreven aan de hand van een aantal achtergrondkenmerken. Het gaat hierbij om een drietal persoonsgerelateerde kenmerken en een aantal kenmerken van de EAQ-opleiding en Yan fe Yonrnn|fiding

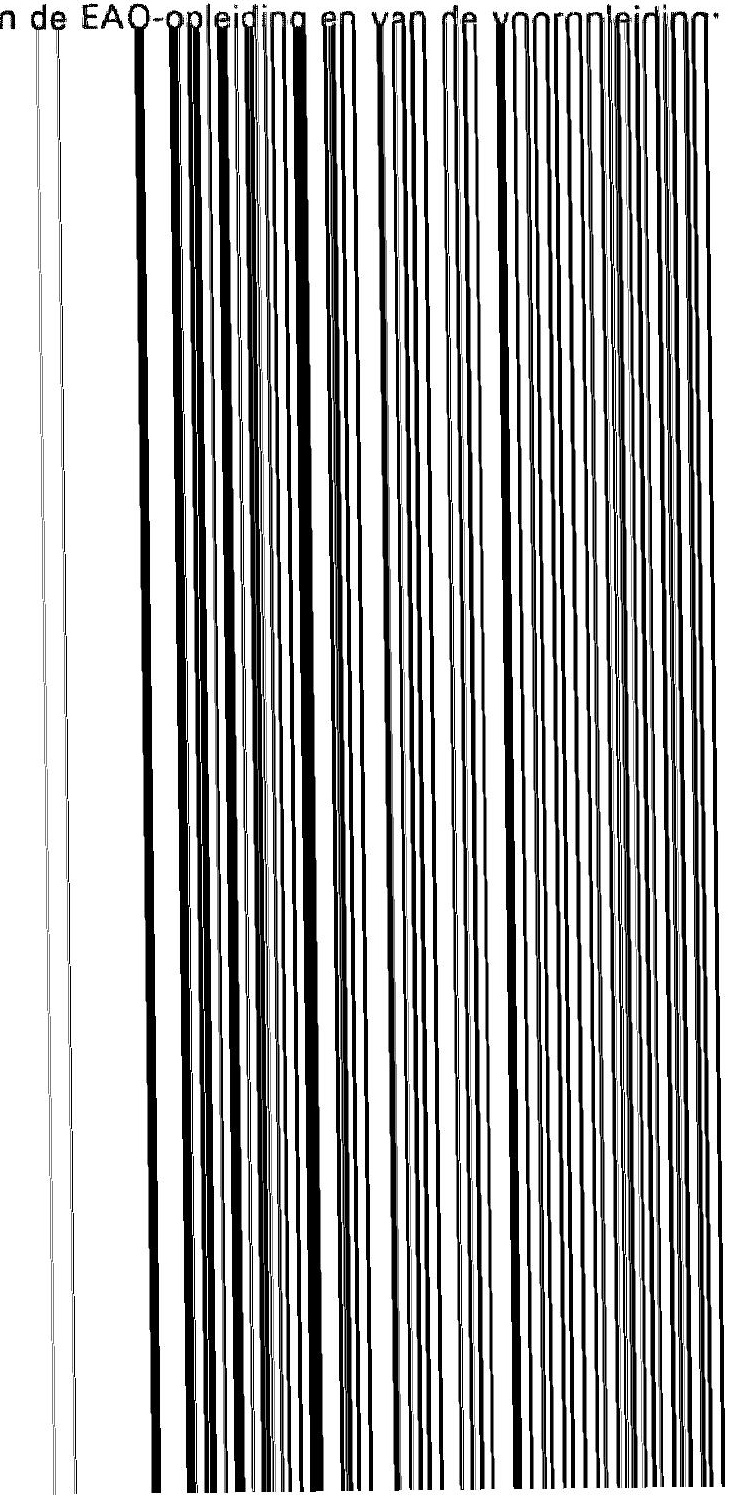




\section{PERSOONSKENMERKEN EN GENOTEN OPLEIDING}

\subsection{Inleiding}

De aan de EAO-school gevolgde vakrichting alsmede het resultaat waarmee men deze opleiding heeft verlaten, vormt de eerste invalshoek van waaruit de arbeidsmarktbestemming inzichtelijk kan worden gemaakt. De verklaring van eventuele verschillen in arbeidsmarktbestemming die zich beperkt tot het aspect vakrichting en opleidingsresultaat is onvolledig, omdat de mate van succes op de arbeidsmarkt ook kan afhangen van extra kwalificaties in de vorm van een voltooide vooropleiding en een aantal individuele achtergrondkenmerken van de schoolverlaters.

In dit hoofdstuk worden de onderzochte EAO-schoolverlaters achtereenvolgens beschreven aan de hand van een aantal achtergrondkenmerken. Het gaat hierbij om een drietal persoonsgerelateerde kenmerken en een aantal kenmerken van de EAQ-opleiding en Yan fe Yonrnn|fiding

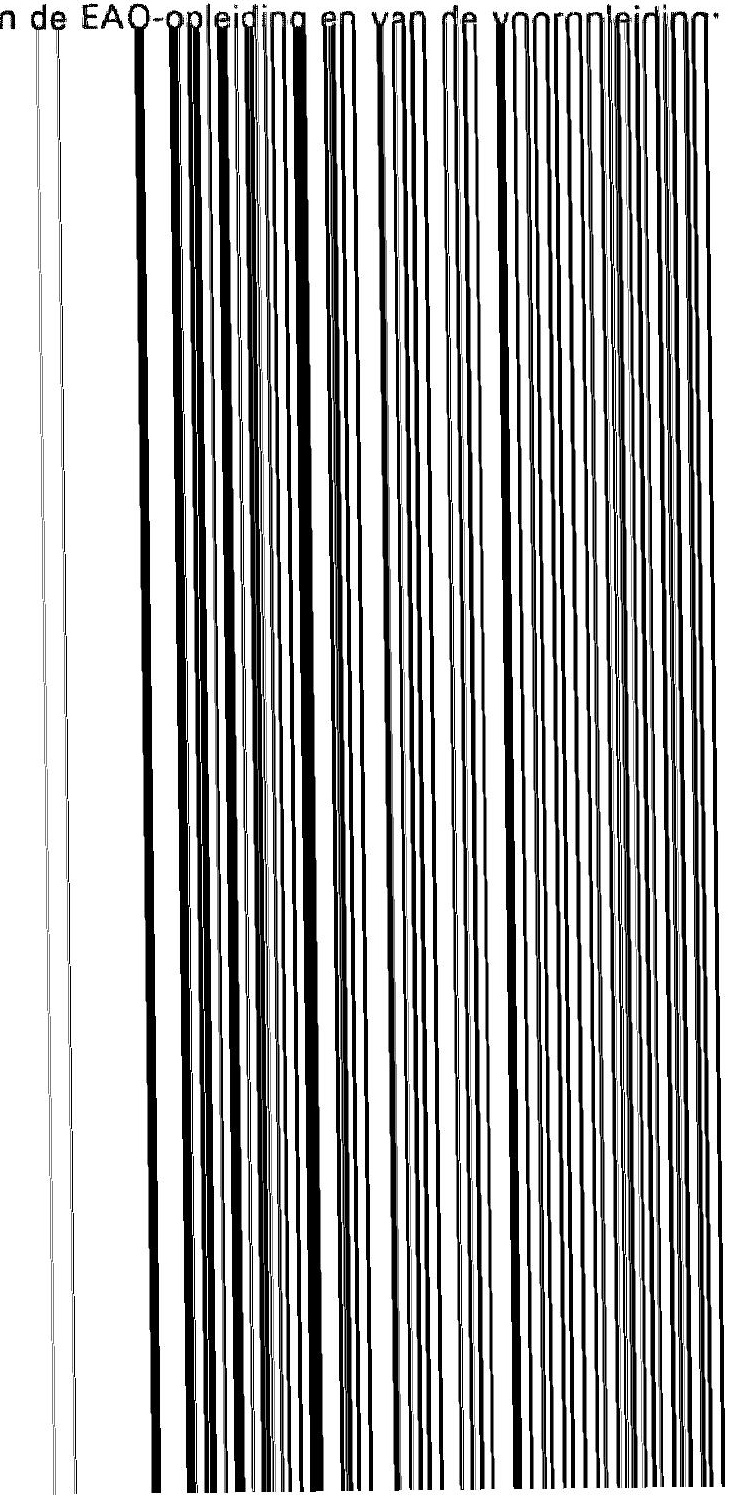




\section{PERSOONSKENMERKEN EN GENOTEN OPLEIDING}

\subsection{Inleiding}

De aan de EAO-school gevolgde vakrichting alsmede het resultaat waarmee men deze opleiding heeft verlaten, vormt de eerste invalshoek van waaruit de arbeidsmarktbestemming inzichtelijk kan worden gemaakt. De verklaring van eventuele verschillen in arbeidsmarktbestemming die zich beperkt tot het aspect vakrichting en opleidingsresultaat is onvolledig, omdat de mate van succes op de arbeidsmarkt ook kan afhangen van extra kwalificaties in de vorm van een voltooide vooropleiding en een aantal individuele achtergrondkenmerken van de schoolverlaters.

In dit hoofdstuk worden de onderzochte EAO-schoolverlaters achtereenvolgens beschreven aan de hand van een aantal achtergrondkenmerken. Het gaat hierbij om een drietal persoonsgerelateerde kenmerken en een aantal kenmerken van de EAQ-opleiding en Yan fe Yonrnn|fiding

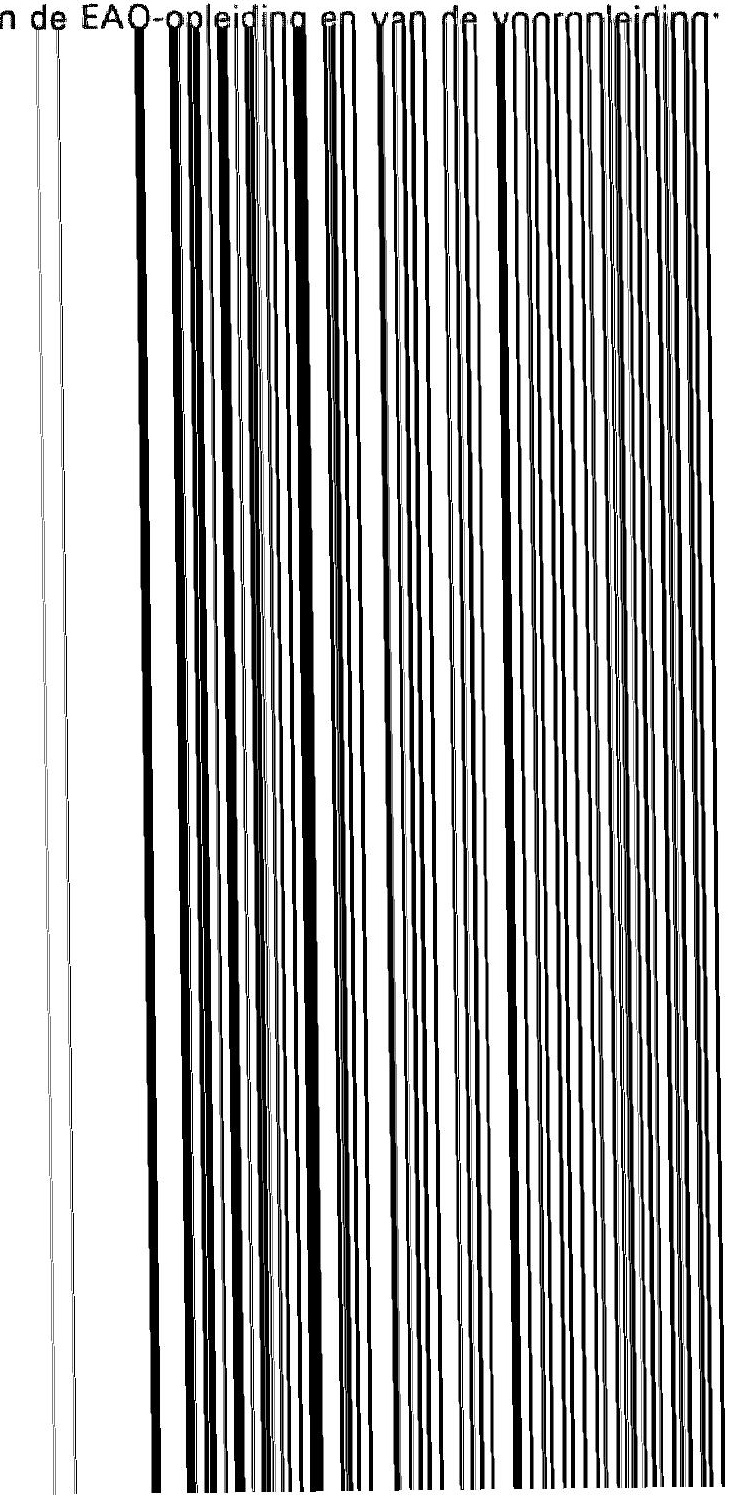




\section{PERSOONSKENMERKEN EN GENOTEN OPLEIDING}

\subsection{Inleiding}

De aan de EAO-school gevolgde vakrichting alsmede het resultaat waarmee men deze opleiding heeft verlaten, vormt de eerste invalshoek van waaruit de arbeidsmarktbestemming inzichtelijk kan worden gemaakt. De verklaring van eventuele verschillen in arbeidsmarktbestemming die zich beperkt tot het aspect vakrichting en opleidingsresultaat is onvolledig, omdat de mate van succes op de arbeidsmarkt ook kan afhangen van extra kwalificaties in de vorm van een voltooide vooropleiding en een aantal individuele achtergrondkenmerken van de schoolverlaters.

In dit hoofdstuk worden de onderzochte EAO-schoolverlaters achtereenvolgens beschreven aan de hand van een aantal achtergrondkenmerken. Het gaat hierbij om een drietal persoonsgerelateerde kenmerken en een aantal kenmerken van de EAQ-opleiding en Yan fe Yonrnn|fiding

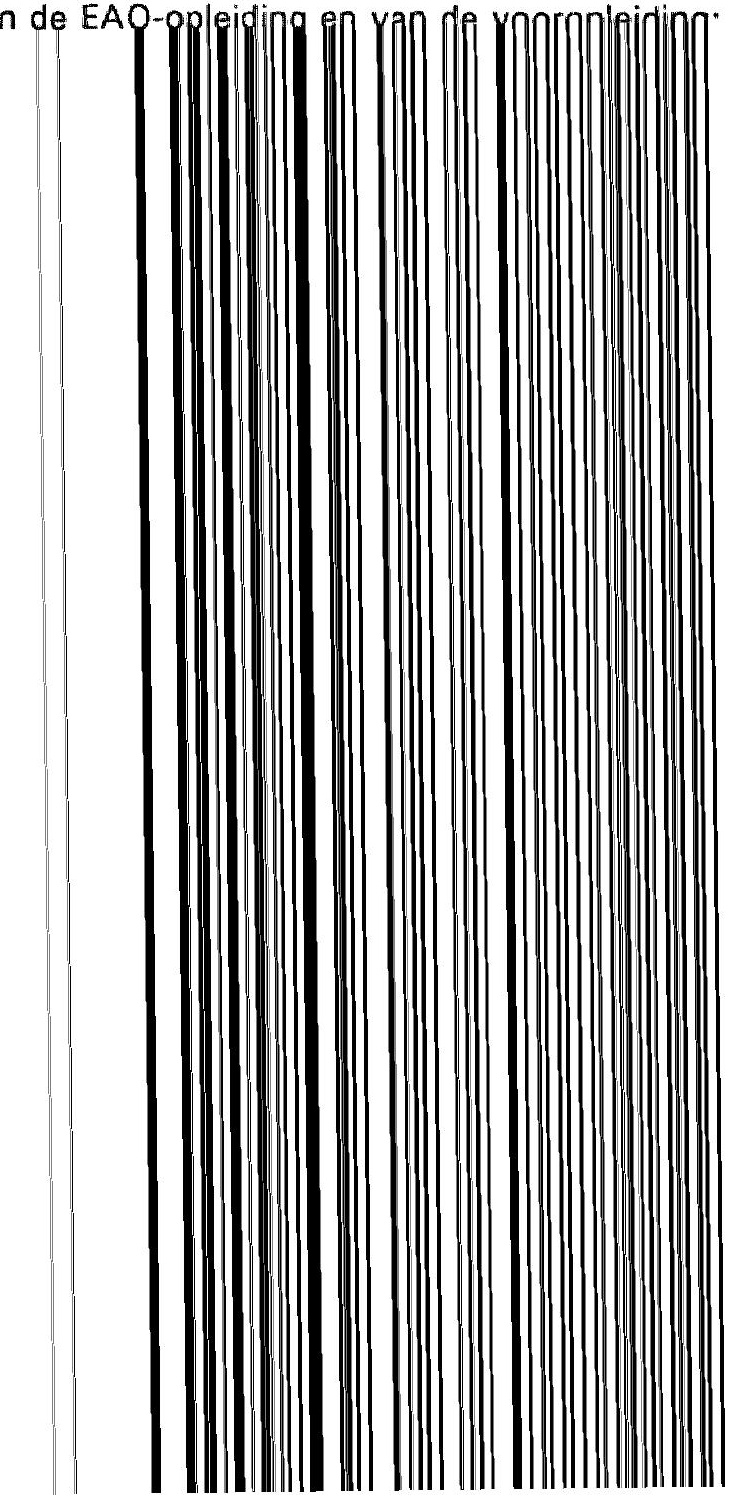




\section{PERSOONSKENMERKEN EN GENOTEN OPLEIDING}

\subsection{Inleiding}

De aan de EAO-school gevolgde vakrichting alsmede het resultaat waarmee men deze opleiding heeft verlaten, vormt de eerste invalshoek van waaruit de arbeidsmarktbestemming inzichtelijk kan worden gemaakt. De verklaring van eventuele verschillen in arbeidsmarktbestemming die zich beperkt tot het aspect vakrichting en opleidingsresultaat is onvolledig, omdat de mate van succes op de arbeidsmarkt ook kan afhangen van extra kwalificaties in de vorm van een voltooide vooropleiding en een aantal individuele achtergrondkenmerken van de schoolverlaters.

In dit hoofdstuk worden de onderzochte EAO-schoolverlaters achtereenvolgens beschreven aan de hand van een aantal achtergrondkenmerken. Het gaat hierbij om een drietal persoonsgerelateerde kenmerken en een aantal kenmerken van de EAQ-opleiding en Yan fe Yonrnn|fiding

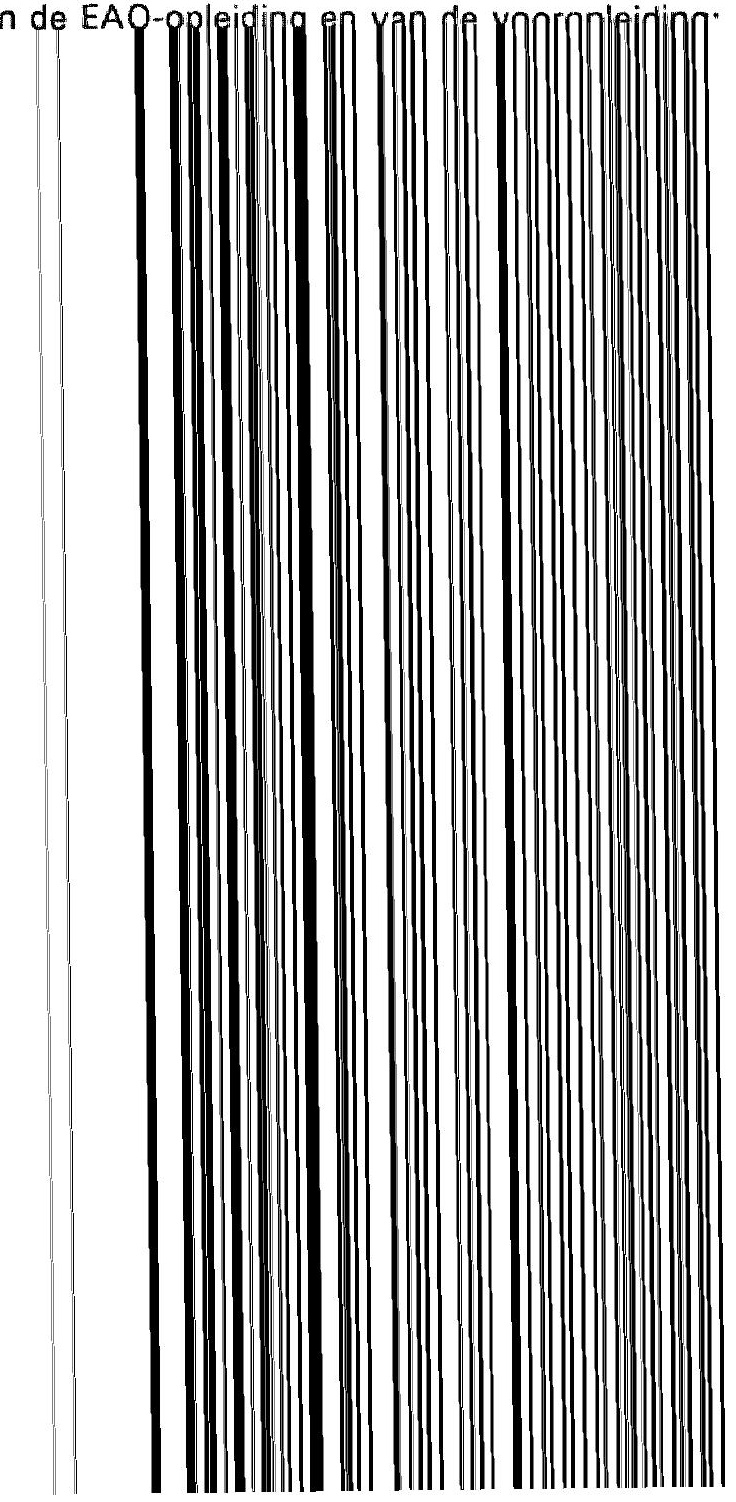




\section{PERSOONSKENMERKEN EN GENOTEN OPLEIDING}

\subsection{Inleiding}

De aan de EAO-school gevolgde vakrichting alsmede het resultaat waarmee men deze opleiding heeft verlaten, vormt de eerste invalshoek van waaruit de arbeidsmarktbestemming inzichtelijk kan worden gemaakt. De verklaring van eventuele verschillen in arbeidsmarktbestemming die zich beperkt tot het aspect vakrichting en opleidingsresultaat is onvolledig, omdat de mate van succes op de arbeidsmarkt ook kan afhangen van extra kwalificaties in de vorm van een voltooide vooropleiding en een aantal individuele achtergrondkenmerken van de schoolverlaters.

In dit hoofdstuk worden de onderzochte EAO-schoolverlaters achtereenvolgens beschreven aan de hand van een aantal achtergrondkenmerken. Het gaat hierbij om een drietal persoonsgerelateerde kenmerken en een aantal kenmerken van de EAQ-opleiding en Yan fe Yonrnn|fiding

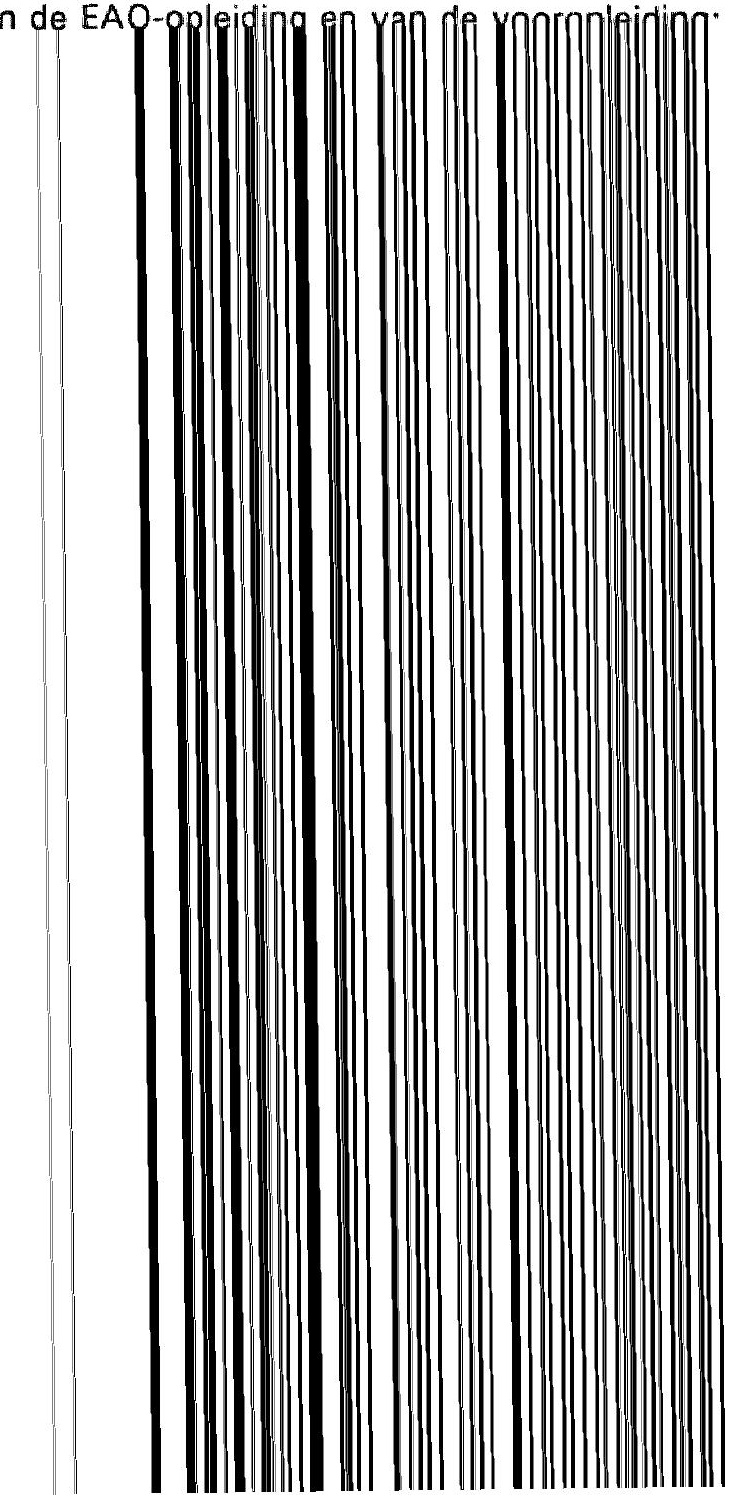




\section{PERSOONSKENMERKEN EN GENOTEN OPLEIDING}

\subsection{Inleiding}

De aan de EAO-school gevolgde vakrichting alsmede het resultaat waarmee men deze opleiding heeft verlaten, vormt de eerste invalshoek van waaruit de arbeidsmarktbestemming inzichtelijk kan worden gemaakt. De verklaring van eventuele verschillen in arbeidsmarktbestemming die zich beperkt tot het aspect vakrichting en opleidingsresultaat is onvolledig, omdat de mate van succes op de arbeidsmarkt ook kan afhangen van extra kwalificaties in de vorm van een voltooide vooropleiding en een aantal individuele achtergrondkenmerken van de schoolverlaters.

In dit hoofdstuk worden de onderzochte EAO-schoolverlaters achtereenvolgens beschreven aan de hand van een aantal achtergrondkenmerken. Het gaat hierbij om een drietal persoonsgerelateerde kenmerken en een aantal kenmerken van de EAQ-opleiding en Yan fe Yonrnn|fiding

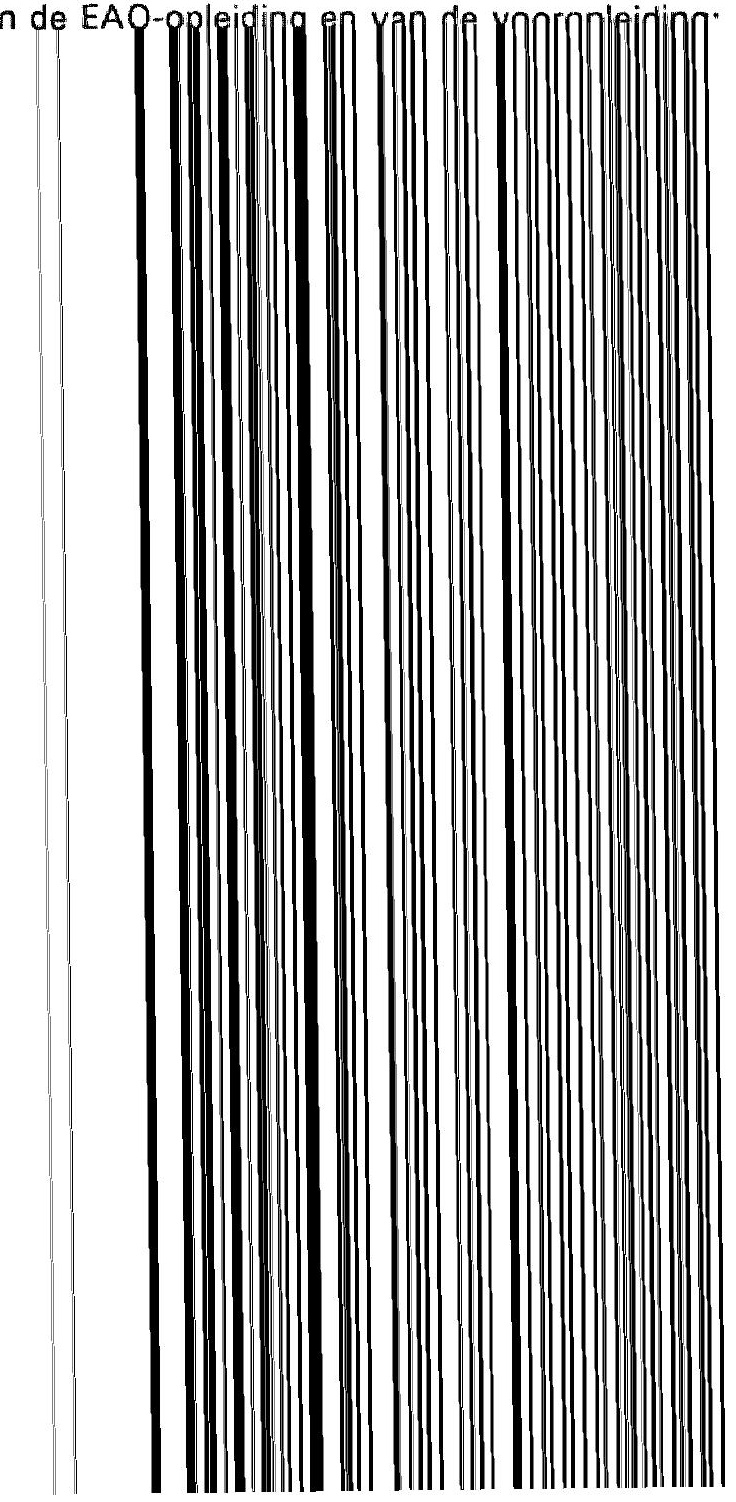




\section{PERSOONSKENMERKEN EN GENOTEN OPLEIDING}

\subsection{Inleiding}

De aan de EAO-school gevolgde vakrichting alsmede het resultaat waarmee men deze opleiding heeft verlaten, vormt de eerste invalshoek van waaruit de arbeidsmarktbestemming inzichtelijk kan worden gemaakt. De verklaring van eventuele verschillen in arbeidsmarktbestemming die zich beperkt tot het aspect vakrichting en opleidingsresultaat is onvolledig, omdat de mate van succes op de arbeidsmarkt ook kan afhangen van extra kwalificaties in de vorm van een voltooide vooropleiding en een aantal individuele achtergrondkenmerken van de schoolverlaters.

In dit hoofdstuk worden de onderzochte EAO-schoolverlaters achtereenvolgens beschreven aan de hand van een aantal achtergrondkenmerken. Het gaat hierbij om een drietal persoonsgerelateerde kenmerken en een aantal kenmerken van de EAQ-opleiding en Yan fe Yonrnn|fiding

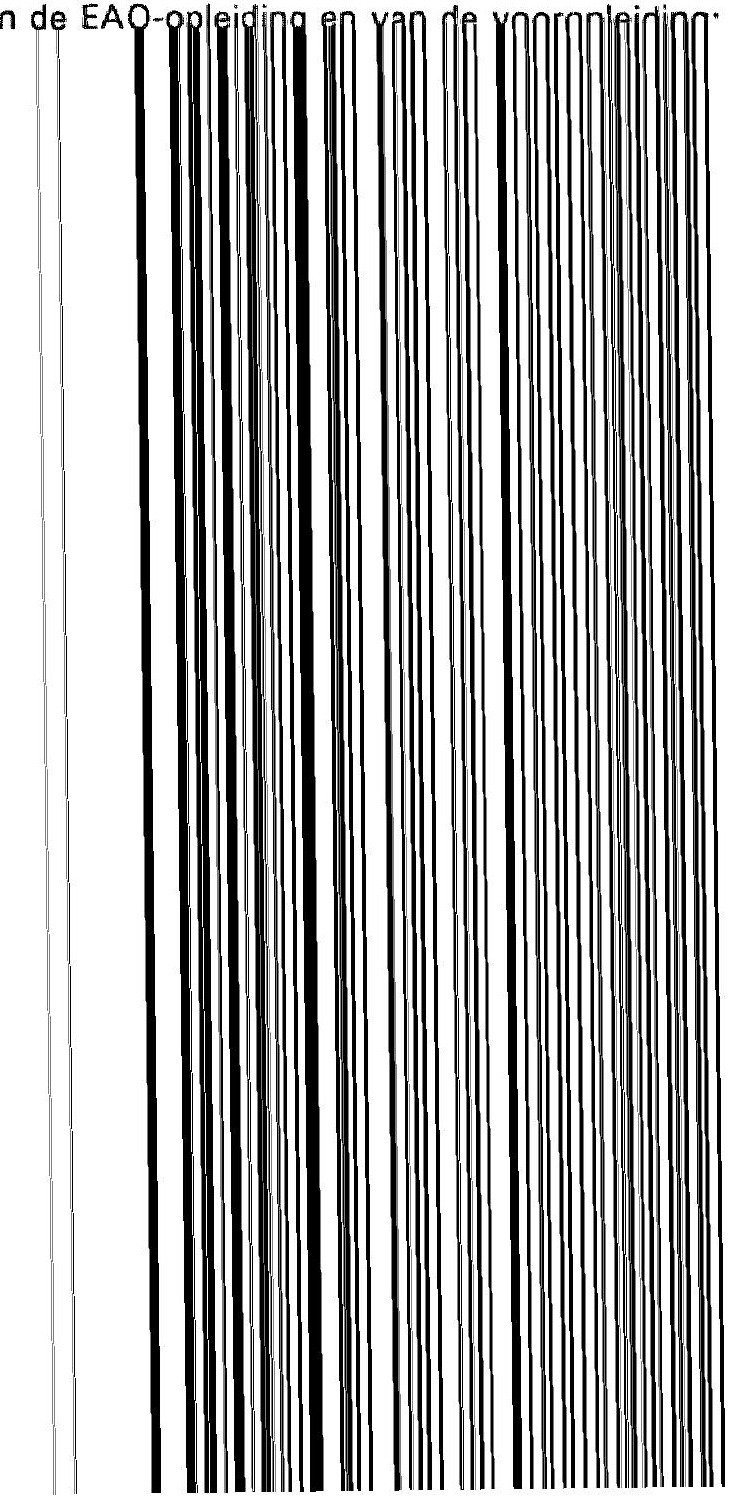




\section{PERSOONSKENMERKEN EN GENOTEN OPLEIDING}

\subsection{Inleiding}

De aan de EAO-school gevolgde vakrichting alsmede het resultaat waarmee men deze opleiding heeft verlaten, vormt de eerste invalshoek van waaruit de arbeidsmarktbestemming inzichtelijk kan worden gemaakt. De verklaring van eventuele verschillen in arbeidsmarktbestemming die zich beperkt tot het aspect vakrichting en opleidingsresultaat is onvolledig, omdat de mate van succes op de arbeidsmarkt ook kan afhangen van extra kwalificaties in de vorm van een voltooide vooropleiding en een aantal individuele achtergrondkenmerken van de schoolverlaters.

In dit hoofdstuk worden de onderzochte EAO-schoolverlaters achtereenvolgens beschreven aan de hand van een aantal achtergrondkenmerken. Het gaat hierbij om een drietal persoonsgerelateerde kenmerken en een aantal kenmerken van de EAQ-opleiding en Yan fe Yonrnn|fiding

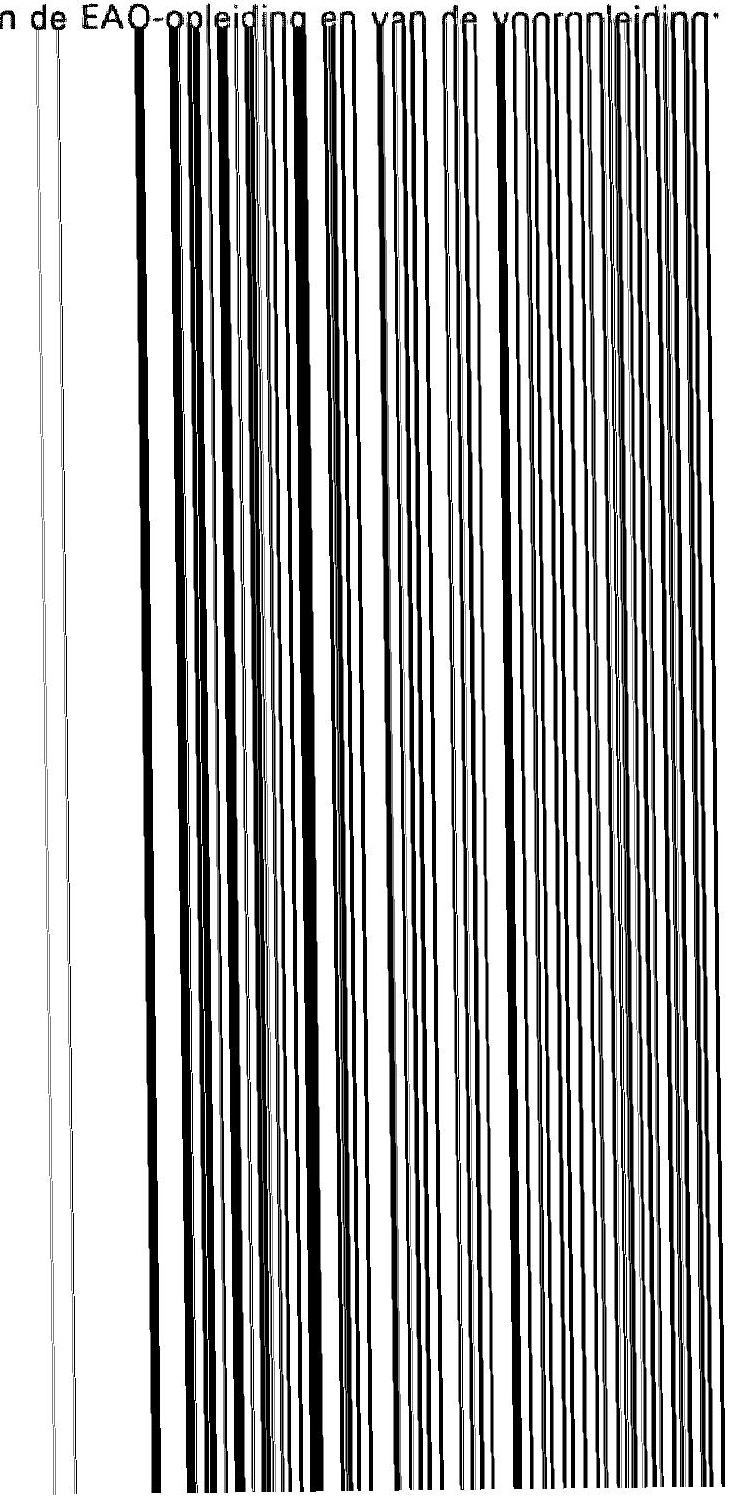




\section{PERSOONSKENMERKEN EN GENOTEN OPLEIDING}

\subsection{Inleiding}

De aan de EAO-school gevolgde vakrichting alsmede het resultaat waarmee men deze opleiding heeft verlaten, vormt de eerste invalshoek van waaruit de arbeidsmarktbestemming inzichtelijk kan worden gemaakt. De verklaring van eventuele verschillen in arbeidsmarktbestemming die zich beperkt tot het aspect vakrichting en opleidingsresultaat is onvolledig, omdat de mate van succes op de arbeidsmarkt ook kan afhangen van extra kwalificaties in de vorm van een voltooide vooropleiding en een aantal individuele achtergrondkenmerken van de schoolverlaters.

In dit hoofdstuk worden de onderzochte EAO-schoolverlaters achtereenvolgens beschreven aan de hand van een aantal achtergrondkenmerken. Het gaat hierbij om een drietal persoonsgerelateerde kenmerken en een aantal kenmerken van de EAQ-opleiding en Yan fe Yonrnn|fiding

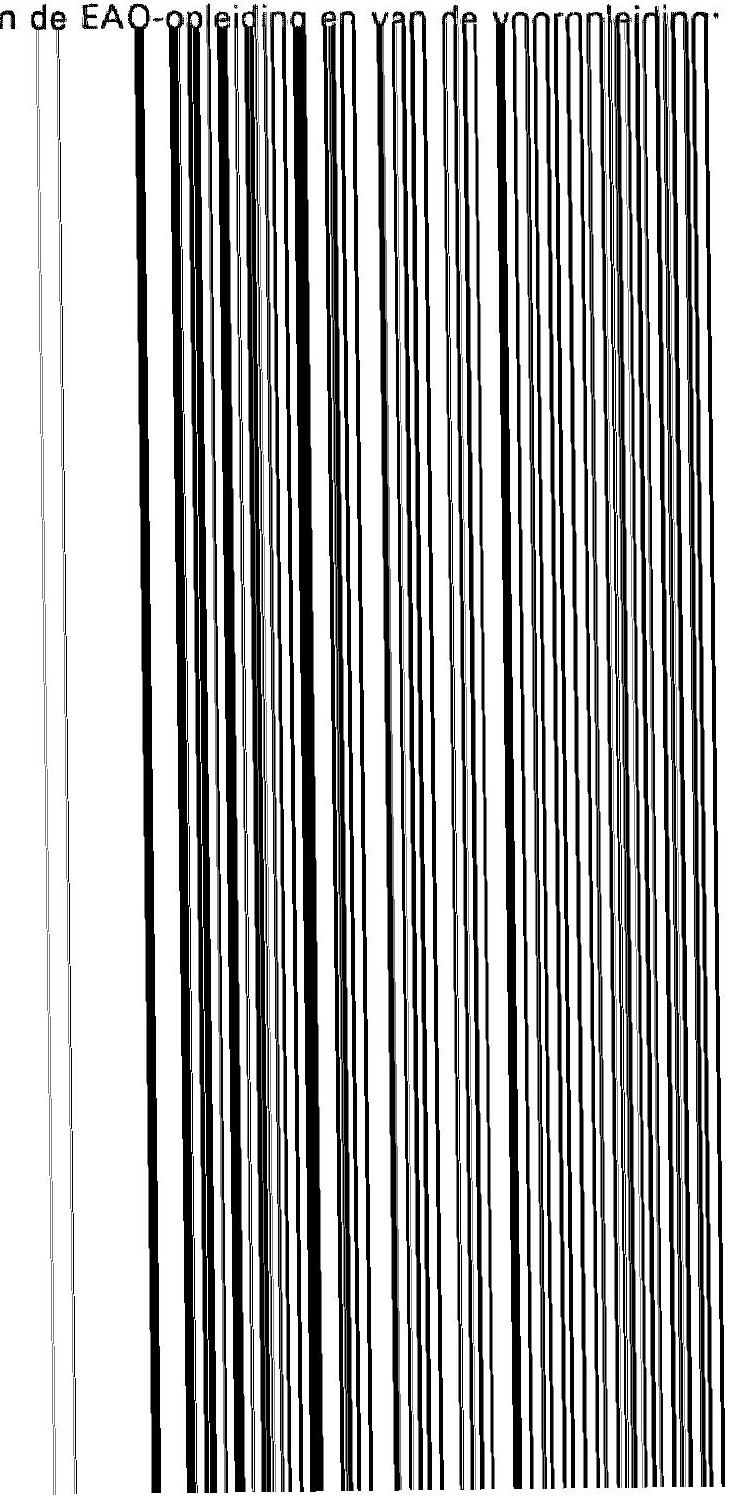




\section{PERSOONSKENMERKEN EN GENOTEN OPLEIDING}

\subsection{Inleiding}

De aan de EAO-school gevolgde vakrichting alsmede het resultaat waarmee men deze opleiding heeft verlaten, vormt de eerste invalshoek van waaruit de arbeidsmarktbestemming inzichtelijk kan worden gemaakt. De verklaring van eventuele verschillen in arbeidsmarktbestemming die zich beperkt tot het aspect vakrichting en opleidingsresultaat is onvolledig, omdat de mate van succes op de arbeidsmarkt ook kan afhangen van extra kwalificaties in de vorm van een voltooide vooropleiding en een aantal individuele achtergrondkenmerken van de schoolverlaters.

In dit hoofdstuk worden de onderzochte EAO-schoolverlaters achtereenvolgens beschreven aan de hand van een aantal achtergrondkenmerken. Het gaat hierbij om een drietal persoonsgerelateerde kenmerken en een aantal kenmerken van de EAQ-opleiding en Yan fe Yonrnn|fiding

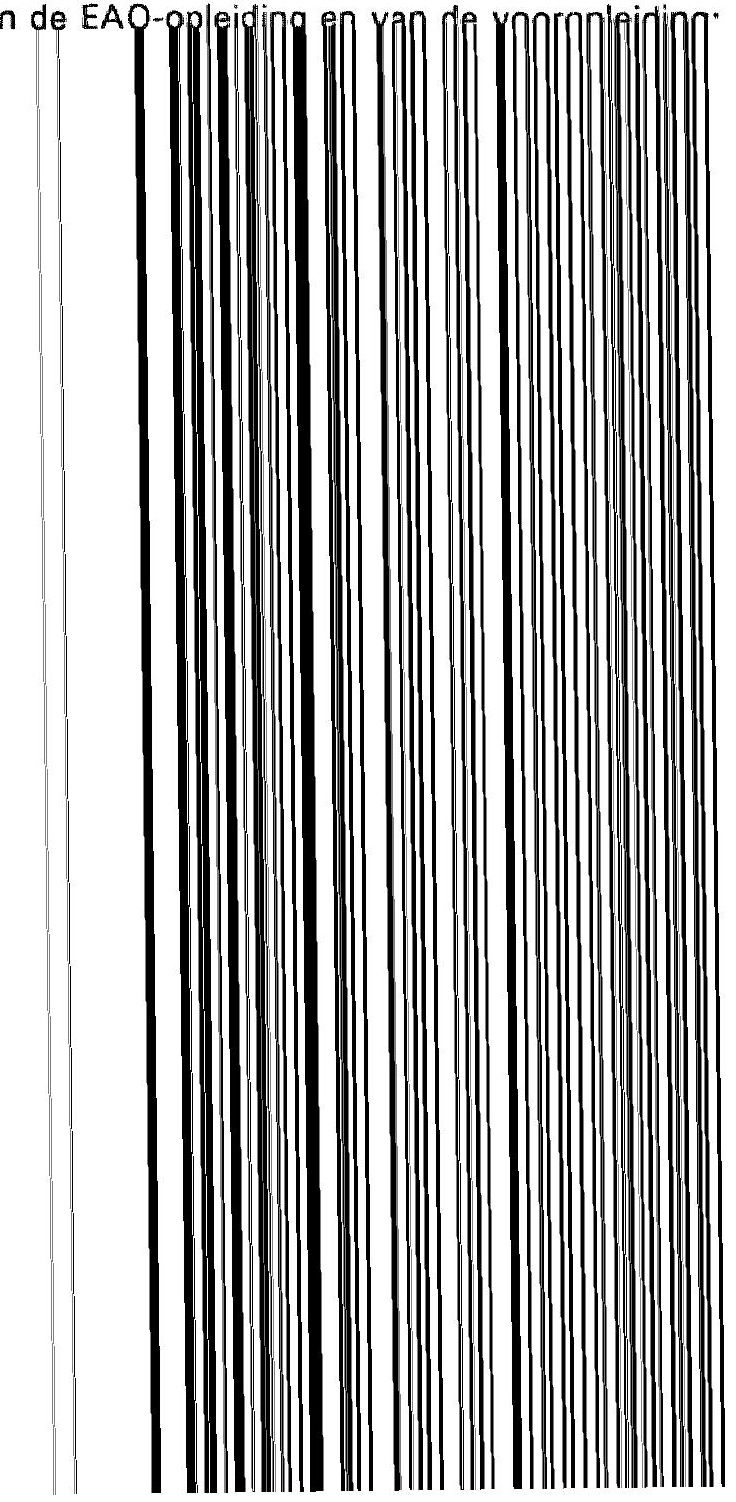




\section{PERSOONSKENMERKEN EN GENOTEN OPLEIDING}

\subsection{Inleiding}

De aan de EAO-school gevolgde vakrichting alsmede het resultaat waarmee men deze opleiding heeft verlaten, vormt de eerste invalshoek van waaruit de arbeidsmarktbestemming inzichtelijk kan worden gemaakt. De verklaring van eventuele verschillen in arbeidsmarktbestemming die zich beperkt tot het aspect vakrichting en opleidingsresultaat is onvolledig, omdat de mate van succes op de arbeidsmarkt ook kan afhangen van extra kwalificaties in de vorm van een voltooide vooropleiding en een aantal individuele achtergrondkenmerken van de schoolverlaters.

In dit hoofdstuk worden de onderzochte EAO-schoolverlaters achtereenvolgens beschreven aan de hand van een aantal achtergrondkenmerken. Het gaat hierbij om een drietal persoonsgerelateerde kenmerken en een aantal kenmerken van de EAQ-opleiding en Yan fe Yonrnn|fiding

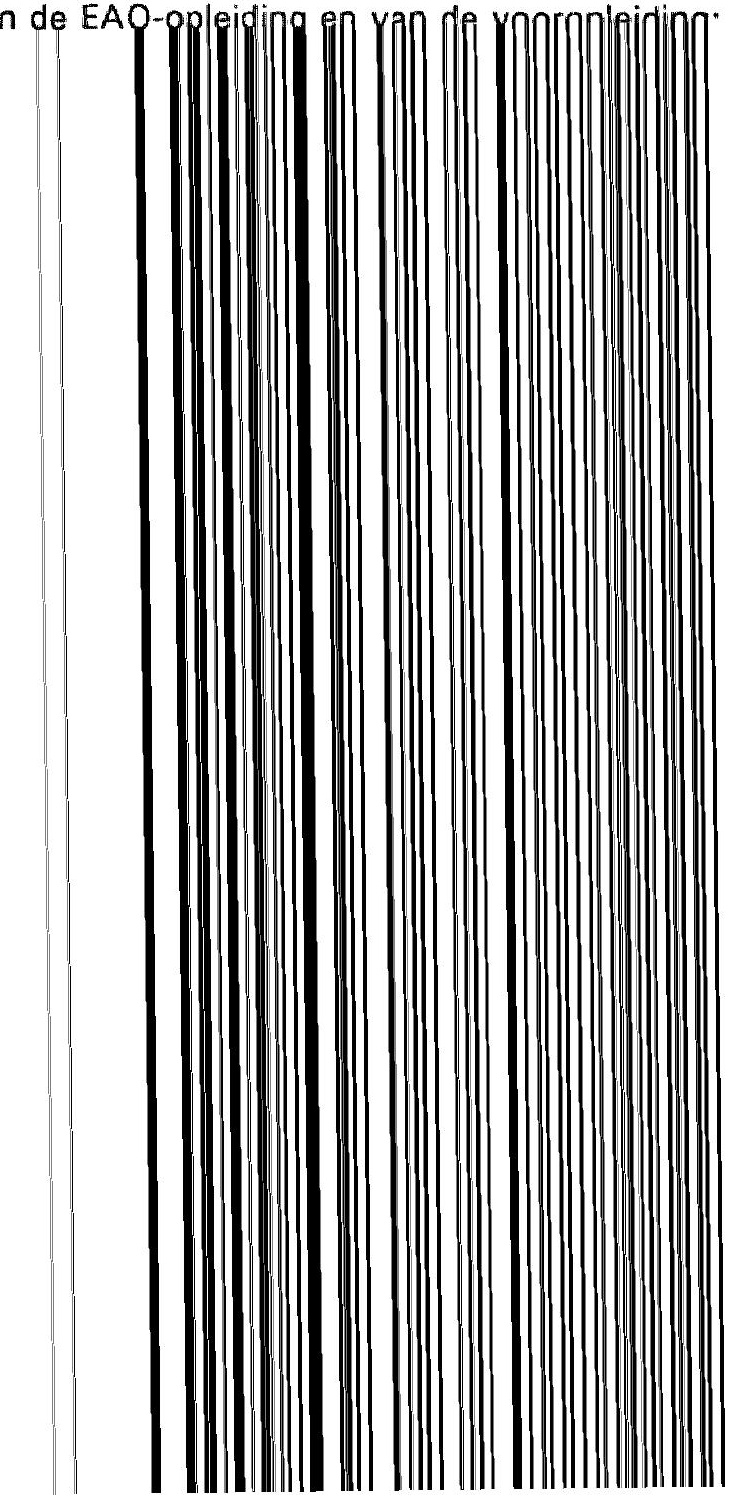




\section{PERSOONSKENMERKEN EN GENOTEN OPLEIDING}

\subsection{Inleiding}

De aan de EAO-school gevolgde vakrichting alsmede het resultaat waarmee men deze opleiding heeft verlaten, vormt de eerste invalshoek van waaruit de arbeidsmarktbestemming inzichtelijk kan worden gemaakt. De verklaring van eventuele verschillen in arbeidsmarktbestemming die zich beperkt tot het aspect vakrichting en opleidingsresultaat is onvolledig, omdat de mate van succes op de arbeidsmarkt ook kan afhangen van extra kwalificaties in de vorm van een voltooide vooropleiding en een aantal individuele achtergrondkenmerken van de schoolverlaters.

In dit hoofdstuk worden de onderzochte EAO-schoolverlaters achtereenvolgens beschreven aan de hand van een aantal achtergrondkenmerken. Het gaat hierbij om een drietal persoonsgerelateerde kenmerken en een aantal kenmerken van de EAQ-opleiding en Yan fe Yonrnn|fiding

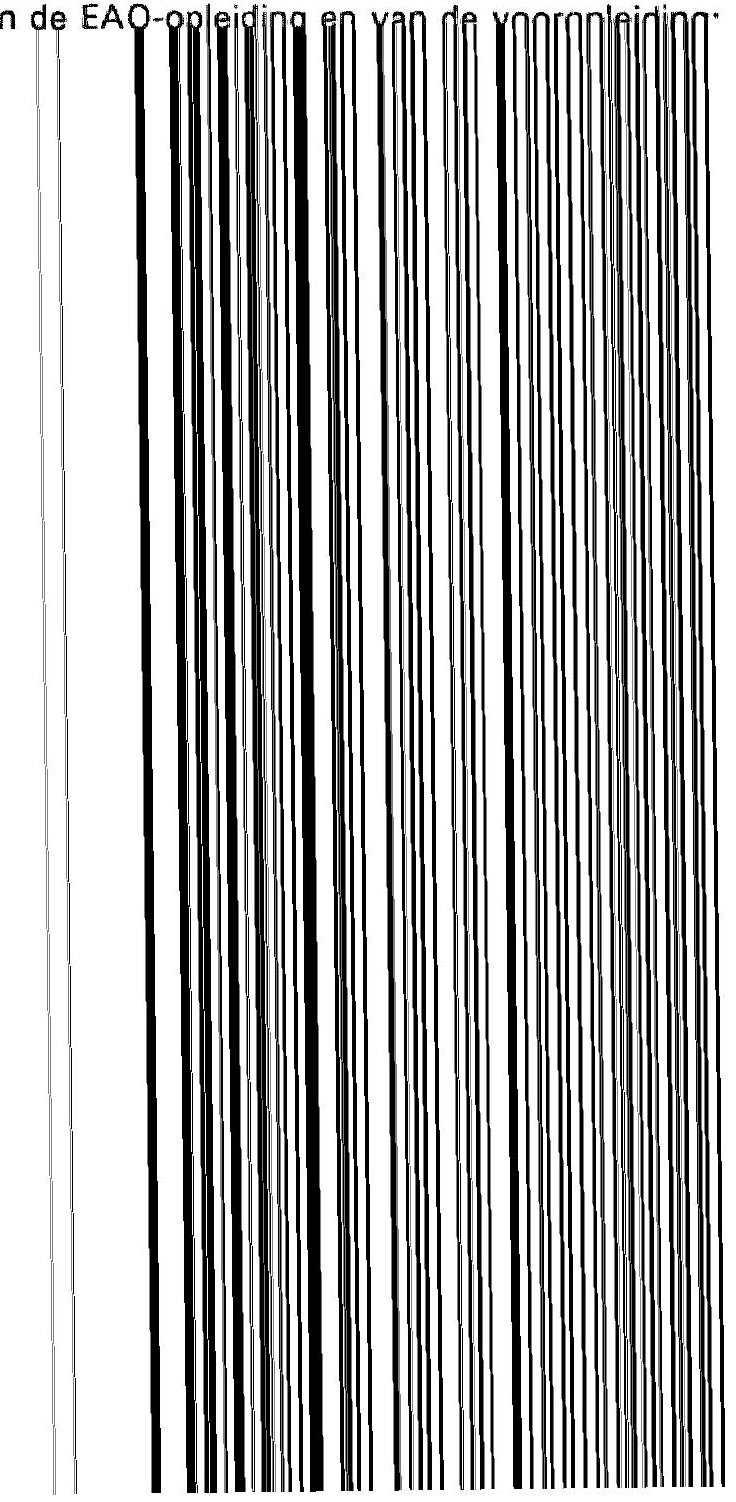




\section{PERSOONSKENMERKEN EN GENOTEN OPLEIDING}

\subsection{Inleiding}

De aan de EAO-school gevolgde vakrichting alsmede het resultaat waarmee men deze opleiding heeft verlaten, vormt de eerste invalshoek van waaruit de arbeidsmarktbestemming inzichtelijk kan worden gemaakt. De verklaring van eventuele verschillen in arbeidsmarktbestemming die zich beperkt tot het aspect vakrichting en opleidingsresultaat is onvolledig, omdat de mate van succes op de arbeidsmarkt ook kan afhangen van extra kwalificaties in de vorm van een voltooide vooropleiding en een aantal individuele achtergrondkenmerken van de schoolverlaters.

In dit hoofdstuk worden de onderzochte EAO-schoolverlaters achtereenvolgens beschreven aan de hand van een aantal achtergrondkenmerken. Het gaat hierbij om een drietal persoonsgerelateerde kenmerken en een aantal kenmerken van de EAQ-opleiding en Yan fe Yonrnn|fiding

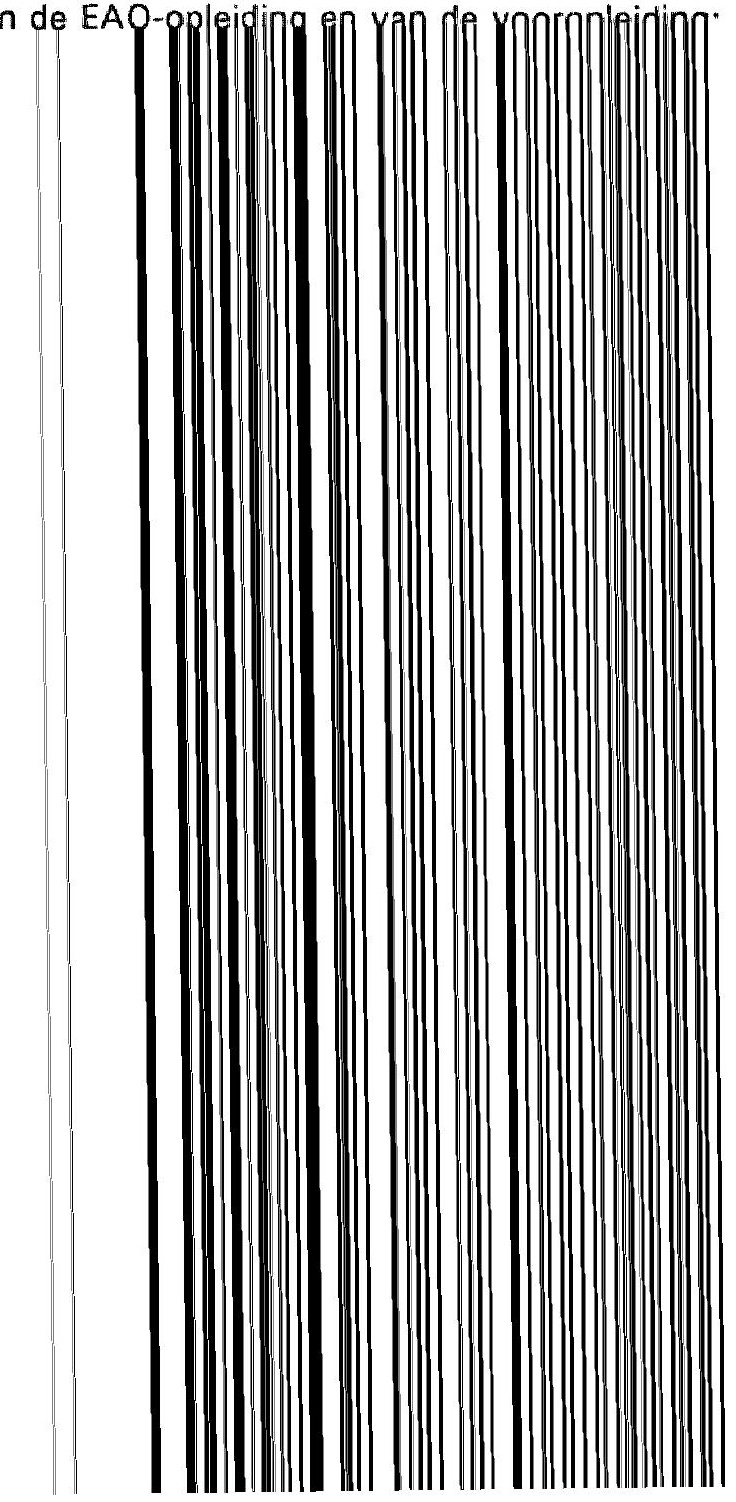




\section{PERSOONSKENMERKEN EN GENOTEN OPLEIDING}

\subsection{Inleiding}

De aan de EAO-school gevolgde vakrichting alsmede het resultaat waarmee men deze opleiding heeft verlaten, vormt de eerste invalshoek van waaruit de arbeidsmarktbestemming inzichtelijk kan worden gemaakt. De verklaring van eventuele verschillen in arbeidsmarktbestemming die zich beperkt tot het aspect vakrichting en opleidingsresultaat is onvolledig, omdat de mate van succes op de arbeidsmarkt ook kan afhangen van extra kwalificaties in de vorm van een voltooide vooropleiding en een aantal individuele achtergrondkenmerken van de schoolverlaters.

In dit hoofdstuk worden de onderzochte EAO-schoolverlaters achtereenvolgens beschreven aan de hand van een aantal achtergrondkenmerken. Het gaat hierbij om een drietal persoonsgerelateerde kenmerken en een aantal kenmerken van de EAQ-opleiding en Yan fe Yonrnn|fiding

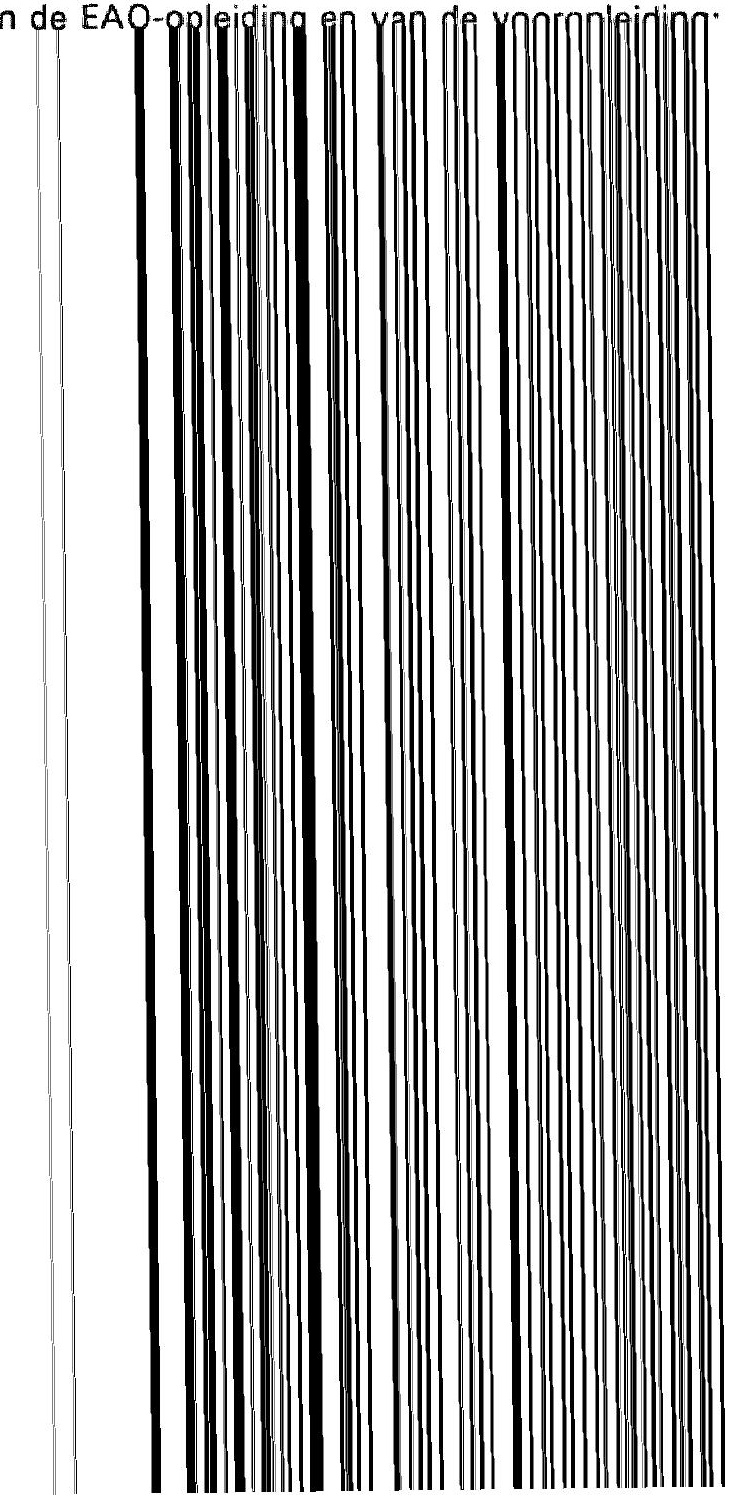




\section{PERSOONSKENMERKEN EN GENOTEN OPLEIDING}

\subsection{Inleiding}

De aan de EAO-school gevolgde vakrichting alsmede het resultaat waarmee men deze opleiding heeft verlaten, vormt de eerste invalshoek van waaruit de arbeidsmarktbestemming inzichtelijk kan worden gemaakt. De verklaring van eventuele verschillen in arbeidsmarktbestemming die zich beperkt tot het aspect vakrichting en opleidingsresultaat is onvolledig, omdat de mate van succes op de arbeidsmarkt ook kan afhangen van extra kwalificaties in de vorm van een voltooide vooropleiding en een aantal individuele achtergrondkenmerken van de schoolverlaters.

In dit hoofdstuk worden de onderzochte EAO-schoolverlaters achtereenvolgens beschreven aan de hand van een aantal achtergrondkenmerken. Het gaat hierbij om een drietal persoonsgerelateerde kenmerken en een aantal kenmerken van de EAQ-opleiding en Yan fe Yonrnn|fiding

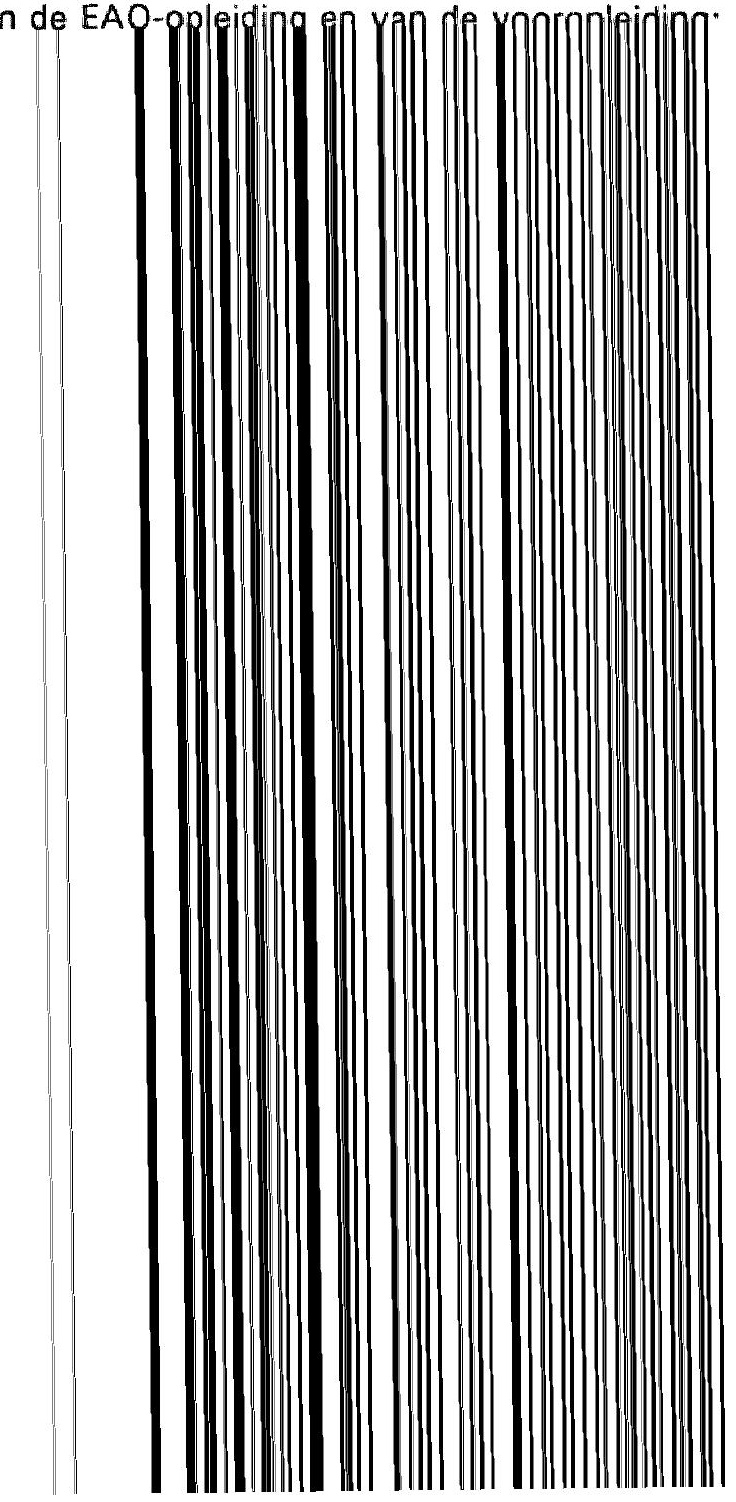




\section{PERSOONSKENMERKEN EN GENOTEN OPLEIDING}

\subsection{Inleiding}

De aan de EAO-school gevolgde vakrichting alsmede het resultaat waarmee men deze opleiding heeft verlaten, vormt de eerste invalshoek van waaruit de arbeidsmarktbestemming inzichtelijk kan worden gemaakt. De verklaring van eventuele verschillen in arbeidsmarktbestemming die zich beperkt tot het aspect vakrichting en opleidingsresultaat is onvolledig, omdat de mate van succes op de arbeidsmarkt ook kan afhangen van extra kwalificaties in de vorm van een voltooide vooropleiding en een aantal individuele achtergrondkenmerken van de schoolverlaters.

In dit hoofdstuk worden de onderzochte EAO-schoolverlaters achtereenvolgens beschreven aan de hand van een aantal achtergrondkenmerken. Het gaat hierbij om een drietal persoonsgerelateerde kenmerken en een aantal kenmerken van de EAQ-opleiding en Yan fe Yonrnn|fiding

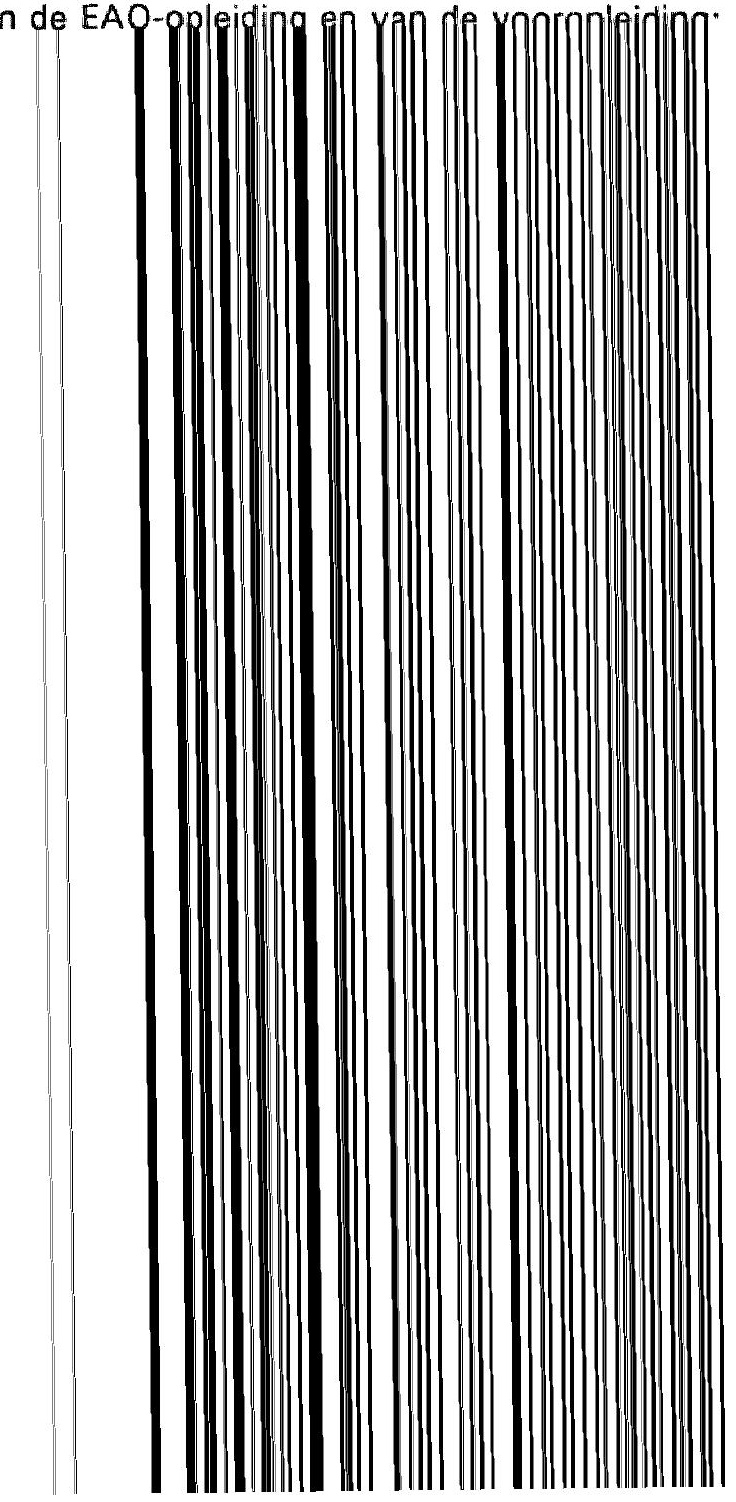




\section{PERSOONSKENMERKEN EN GENOTEN OPLEIDING}

\subsection{Inleiding}

De aan de EAO-school gevolgde vakrichting alsmede het resultaat waarmee men deze opleiding heeft verlaten, vormt de eerste invalshoek van waaruit de arbeidsmarktbestemming inzichtelijk kan worden gemaakt. De verklaring van eventuele verschillen in arbeidsmarktbestemming die zich beperkt tot het aspect vakrichting en opleidingsresultaat is onvolledig, omdat de mate van succes op de arbeidsmarkt ook kan afhangen van extra kwalificaties in de vorm van een voltooide vooropleiding en een aantal individuele achtergrondkenmerken van de schoolverlaters.

In dit hoofdstuk worden de onderzochte EAO-schoolverlaters achtereenvolgens beschreven aan de hand van een aantal achtergrondkenmerken. Het gaat hierbij om een drietal persoonsgerelateerde kenmerken en een aantal kenmerken van de EAQ-opleiding en Yan fe Yonrnn|fiding

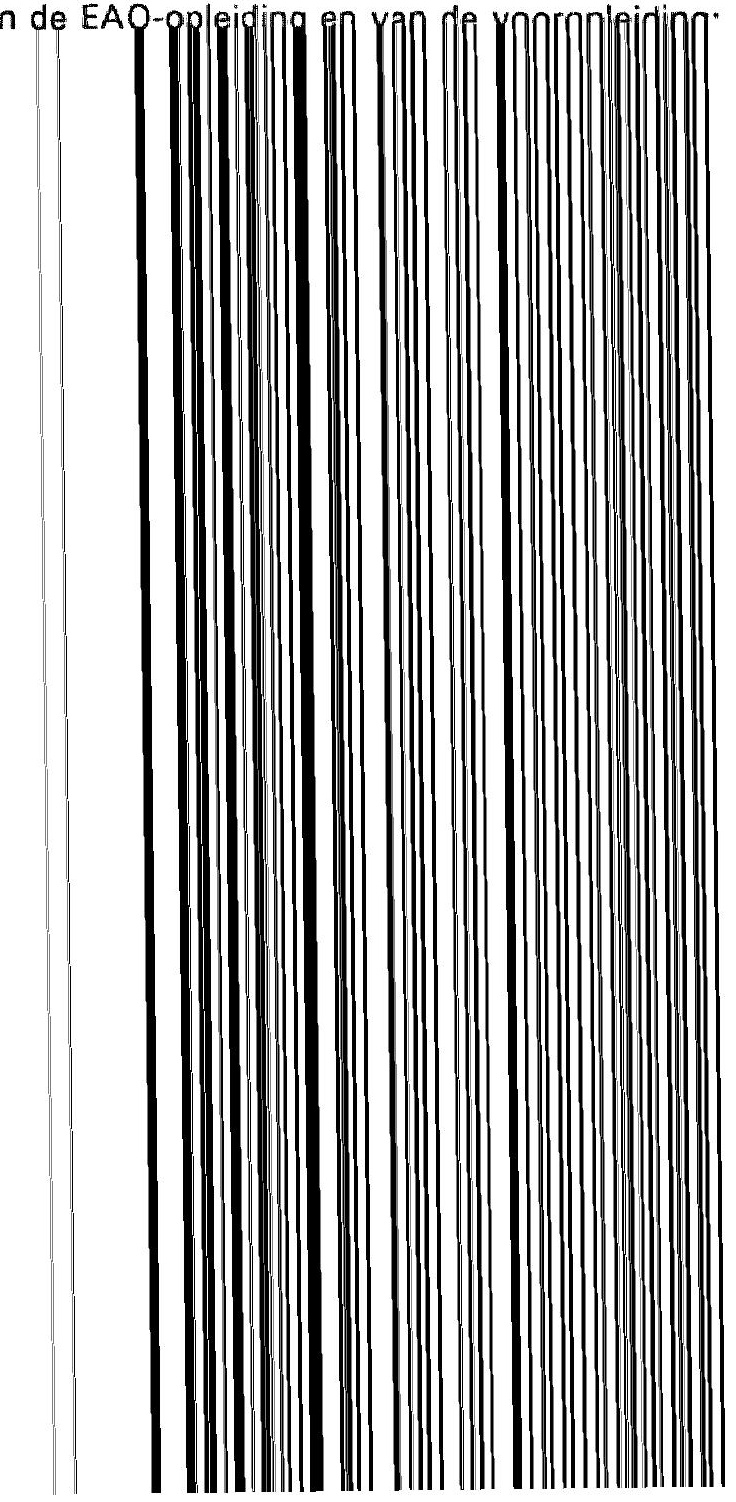




\section{PERSOONSKENMERKEN EN GENOTEN OPLEIDING}

\subsection{Inleiding}

De aan de EAO-school gevolgde vakrichting alsmede het resultaat waarmee men deze opleiding heeft verlaten, vormt de eerste invalshoek van waaruit de arbeidsmarktbestemming inzichtelijk kan worden gemaakt. De verklaring van eventuele verschillen in arbeidsmarktbestemming die zich beperkt tot het aspect vakrichting en opleidingsresultaat is onvolledig, omdat de mate van succes op de arbeidsmarkt ook kan afhangen van extra kwalificaties in de vorm van een voltooide vooropleiding en een aantal individuele achtergrondkenmerken van de schoolverlaters.

In dit hoofdstuk worden de onderzochte EAO-schoolverlaters achtereenvolgens beschreven aan de hand van een aantal achtergrondkenmerken. Het gaat hierbij om een drietal persoonsgerelateerde kenmerken en een aantal kenmerken van de EAQ-opleiding en Yan fe Yonrnn|fiding

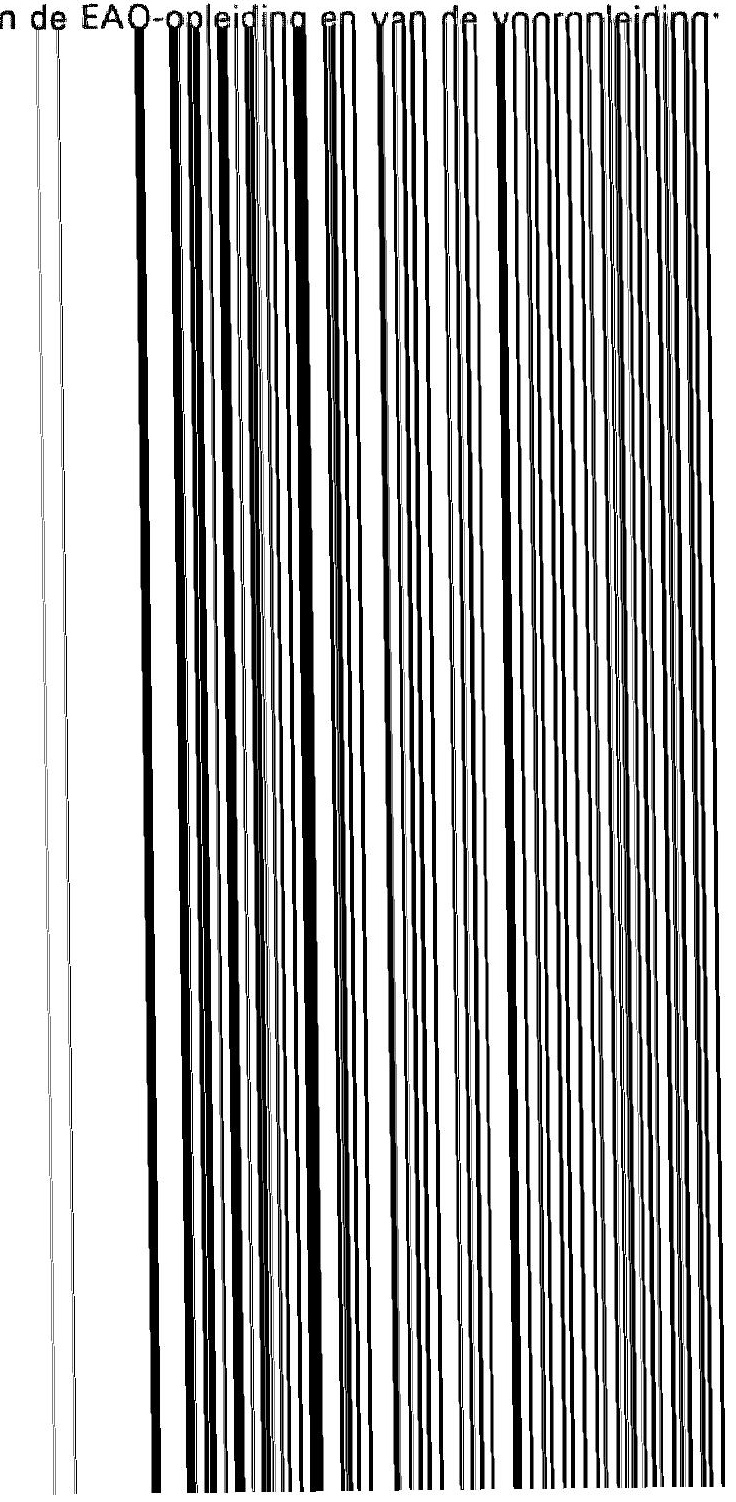




\section{PERSOONSKENMERKEN EN GENOTEN OPLEIDING}

\subsection{Inleiding}

De aan de EAO-school gevolgde vakrichting alsmede het resultaat waarmee men deze opleiding heeft verlaten, vormt de eerste invalshoek van waaruit de arbeidsmarktbestemming inzichtelijk kan worden gemaakt. De verklaring van eventuele verschillen in arbeidsmarktbestemming die zich beperkt tot het aspect vakrichting en opleidingsresultaat is onvolledig, omdat de mate van succes op de arbeidsmarkt ook kan afhangen van extra kwalificaties in de vorm van een voltooide vooropleiding en een aantal individuele achtergrondkenmerken van de schoolverlaters.

In dit hoofdstuk worden de onderzochte EAO-schoolverlaters achtereenvolgens beschreven aan de hand van een aantal achtergrondkenmerken. Het gaat hierbij om een drietal persoonsgerelateerde kenmerken en een aantal kenmerken van de EAQ-opleiding en Yan fe Yonrnn|fiding

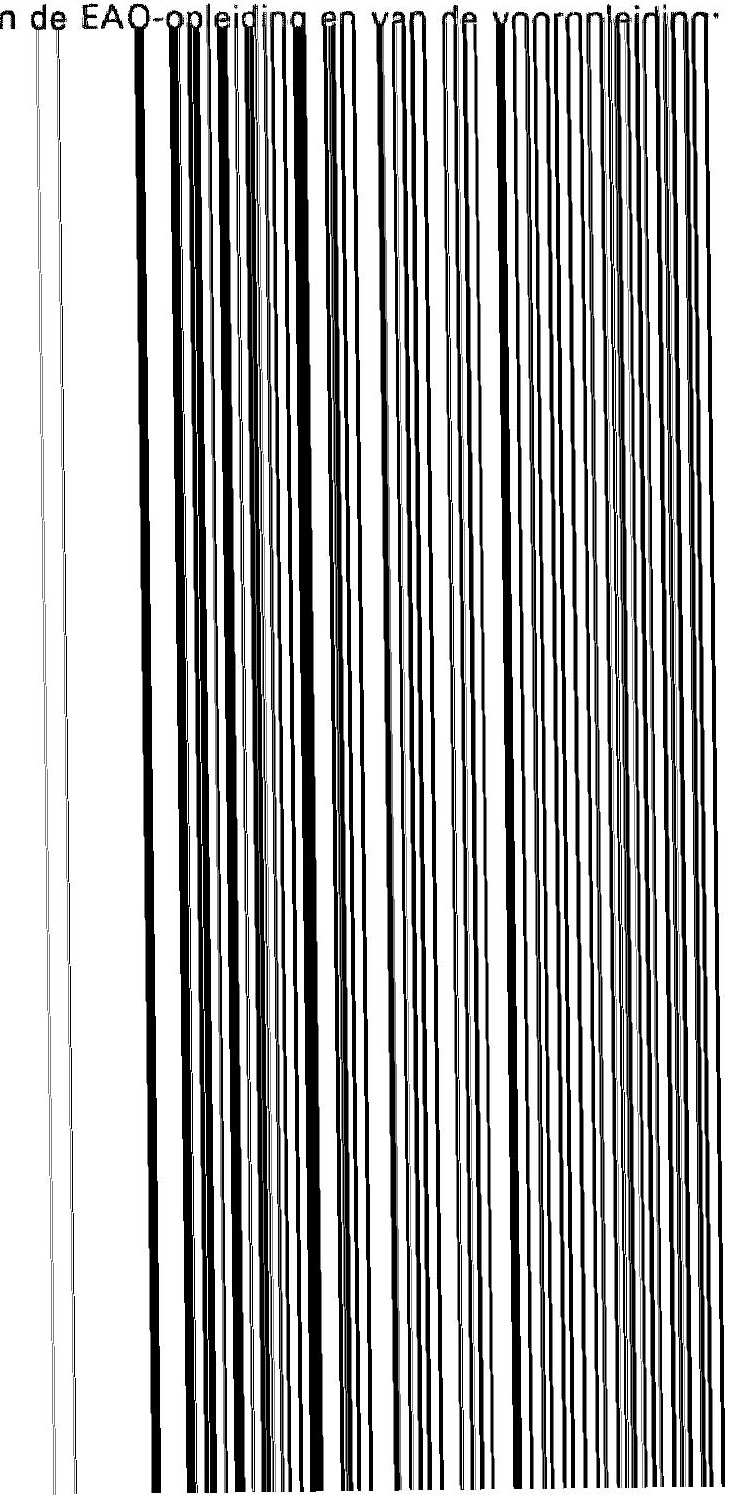




\section{PERSOONSKENMERKEN EN GENOTEN OPLEIDING}

\subsection{Inleiding}

De aan de EAO-school gevolgde vakrichting alsmede het resultaat waarmee men deze opleiding heeft verlaten, vormt de eerste invalshoek van waaruit de arbeidsmarktbestemming inzichtelijk kan worden gemaakt. De verklaring van eventuele verschillen in arbeidsmarktbestemming die zich beperkt tot het aspect vakrichting en opleidingsresultaat is onvolledig, omdat de mate van succes op de arbeidsmarkt ook kan afhangen van extra kwalificaties in de vorm van een voltooide vooropleiding en een aantal individuele achtergrondkenmerken van de schoolverlaters.

In dit hoofdstuk worden de onderzochte EAO-schoolverlaters achtereenvolgens beschreven aan de hand van een aantal achtergrondkenmerken. Het gaat hierbij om een drietal persoonsgerelateerde kenmerken en een aantal kenmerken van de EAQ-opleiding en Yan fe Yonrnn|fiding

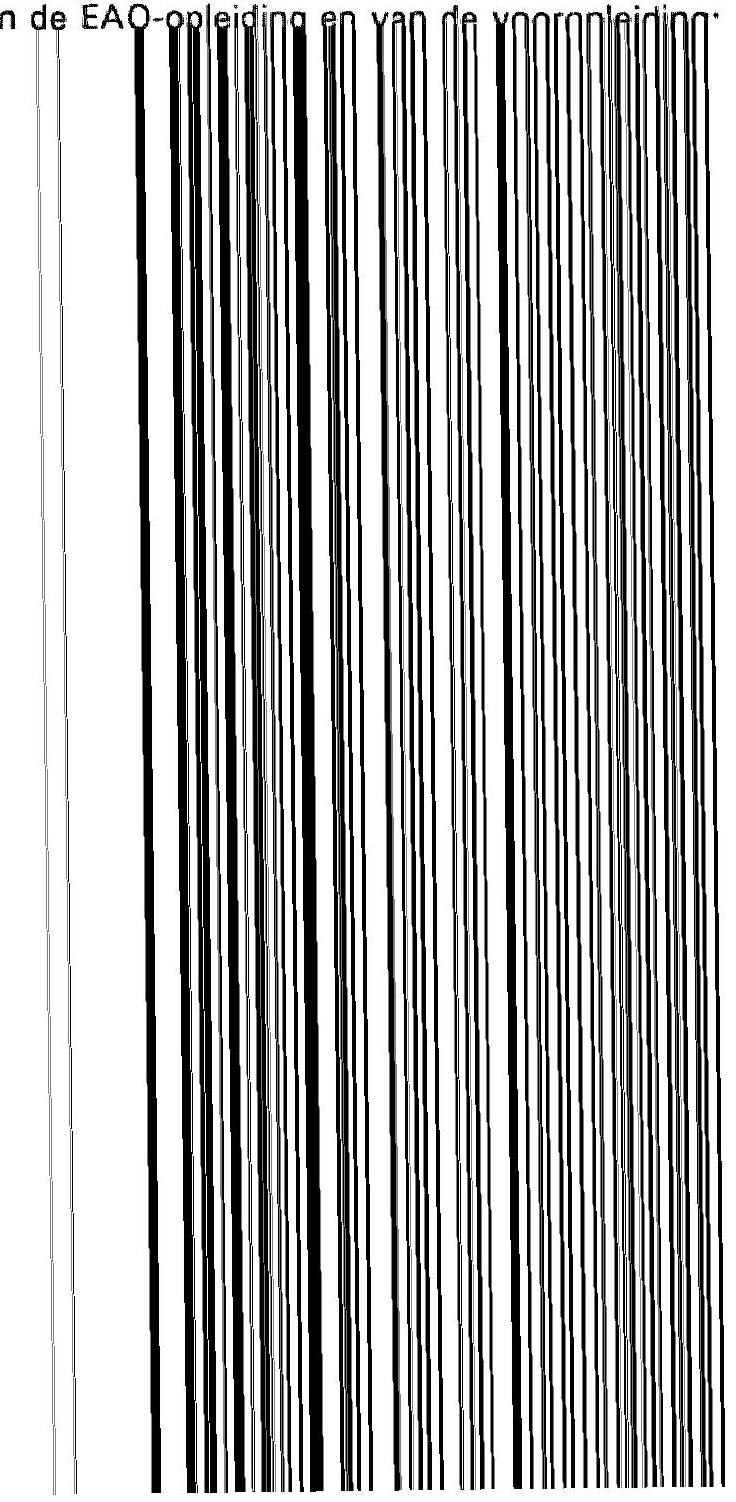




\section{PERSOONSKENMERKEN EN GENOTEN OPLEIDING}

\subsection{Inleiding}

De aan de EAO-school gevolgde vakrichting alsmede het resultaat waarmee men deze opleiding heeft verlaten, vormt de eerste invalshoek van waaruit de arbeidsmarktbestemming inzichtelijk kan worden gemaakt. De verklaring van eventuele verschillen in arbeidsmarktbestemming die zich beperkt tot het aspect vakrichting en opleidingsresultaat is onvolledig, omdat de mate van succes op de arbeidsmarkt ook kan afhangen van extra kwalificaties in de vorm van een voltooide vooropleiding en een aantal individuele achtergrondkenmerken van de schoolverlaters.

In dit hoofdstuk worden de onderzochte EAO-schoolverlaters achtereenvolgens beschreven aan de hand van een aantal achtergrondkenmerken. Het gaat hierbij om een drietal persoonsgerelateerde kenmerken en een aantal kenmerken van de EAQ-opleiding en Yan fe Yonrnn|fiding

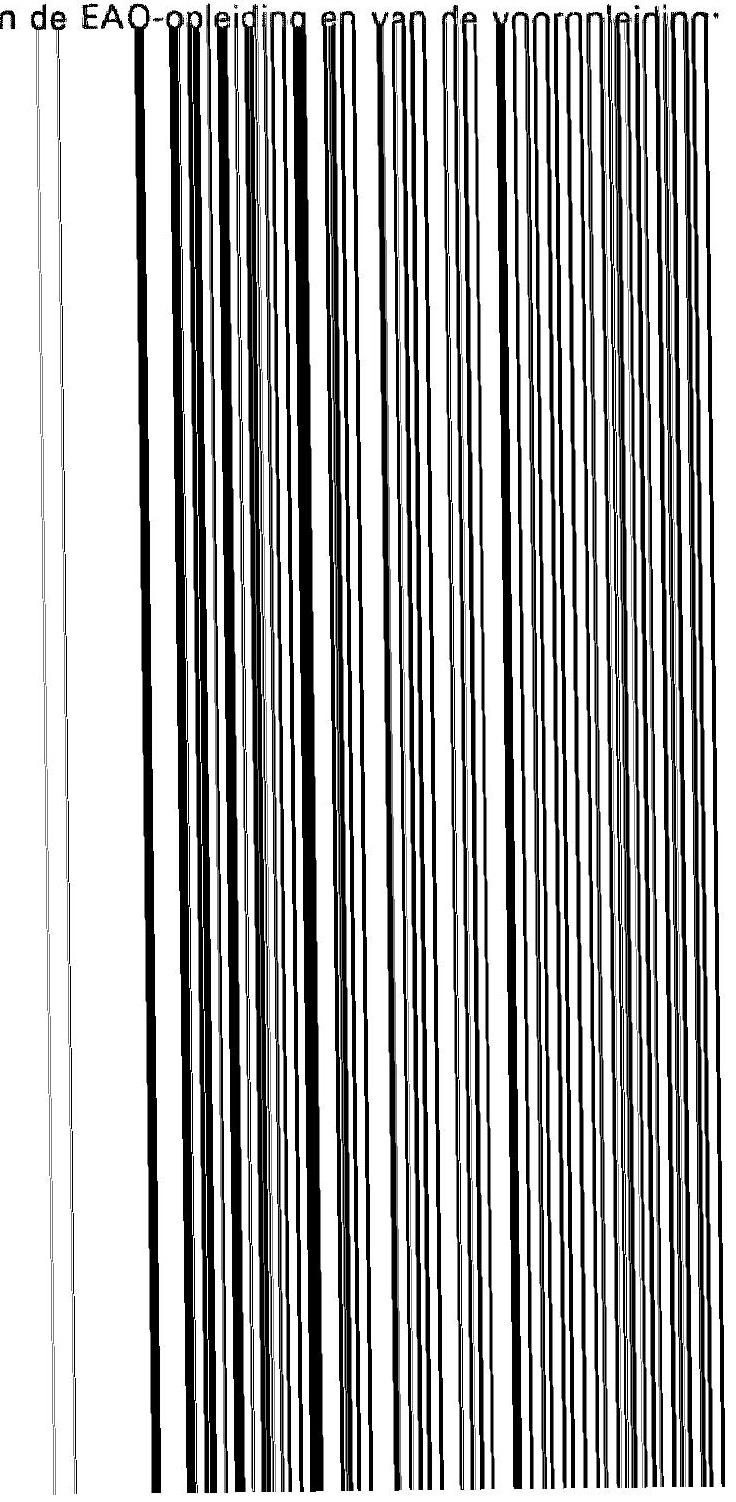




\section{PERSOONSKENMERKEN EN GENOTEN OPLEIDING}

\subsection{Inleiding}

De aan de EAO-school gevolgde vakrichting alsmede het resultaat waarmee men deze opleiding heeft verlaten, vormt de eerste invalshoek van waaruit de arbeidsmarktbestemming inzichtelijk kan worden gemaakt. De verklaring van eventuele verschillen in arbeidsmarktbestemming die zich beperkt tot het aspect vakrichting en opleidingsresultaat is onvolledig, omdat de mate van succes op de arbeidsmarkt ook kan afhangen van extra kwalificaties in de vorm van een voltooide vooropleiding en een aantal individuele achtergrondkenmerken van de schoolverlaters.

In dit hoofdstuk worden de onderzochte EAO-schoolverlaters achtereenvolgens beschreven aan de hand van een aantal achtergrondkenmerken. Het gaat hierbij om een drietal persoonsgerelateerde kenmerken en een aantal kenmerken van de EAQ-opleiding en Yan fe Yonrnn|fiding

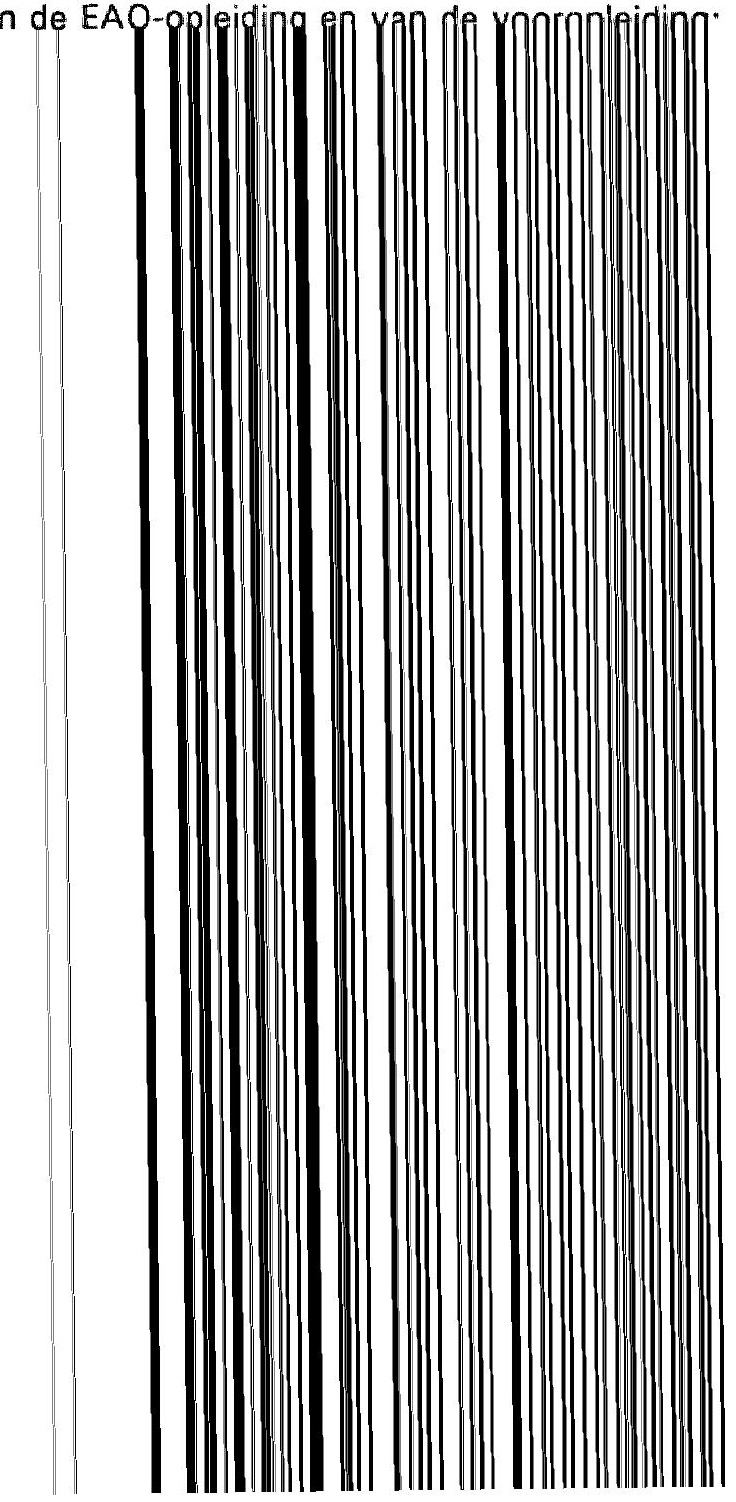




\section{PERSOONSKENMERKEN EN GENOTEN OPLEIDING}

\subsection{Inleiding}

De aan de EAO-school gevolgde vakrichting alsmede het resultaat waarmee men deze opleiding heeft verlaten, vormt de eerste invalshoek van waaruit de arbeidsmarktbestemming inzichtelijk kan worden gemaakt. De verklaring van eventuele verschillen in arbeidsmarktbestemming die zich beperkt tot het aspect vakrichting en opleidingsresultaat is onvolledig, omdat de mate van succes op de arbeidsmarkt ook kan afhangen van extra kwalificaties in de vorm van een voltooide vooropleiding en een aantal individuele achtergrondkenmerken van de schoolverlaters.

In dit hoofdstuk worden de onderzochte EAO-schoolverlaters achtereenvolgens beschreven aan de hand van een aantal achtergrondkenmerken. Het gaat hierbij om een drietal persoonsgerelateerde kenmerken en een aantal kenmerken van de EAQ-opleiding en Yan fe Yonrnn|fiding

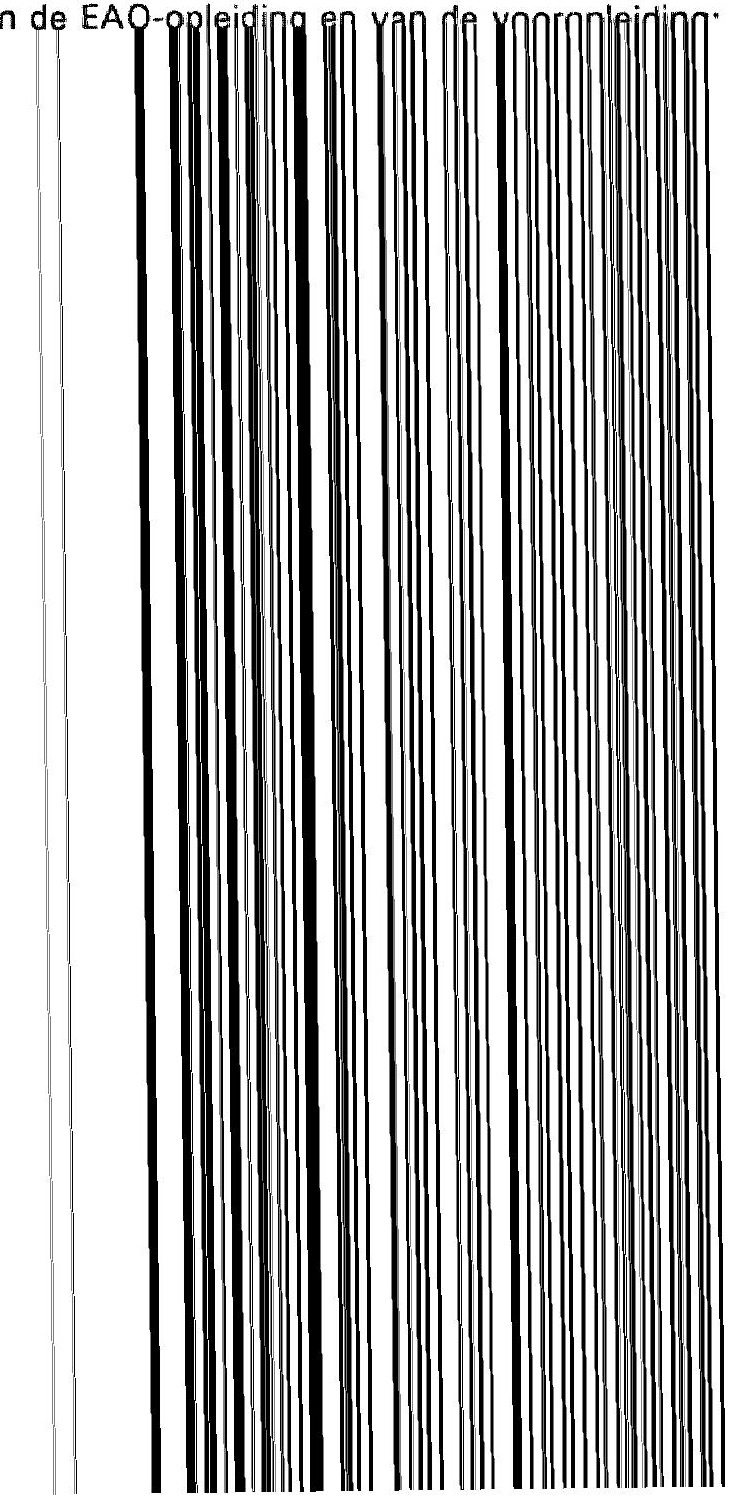




\section{PERSOONSKENMERKEN EN GENOTEN OPLEIDING}

\subsection{Inleiding}

De aan de EAO-school gevolgde vakrichting alsmede het resultaat waarmee men deze opleiding heeft verlaten, vormt de eerste invalshoek van waaruit de arbeidsmarktbestemming inzichtelijk kan worden gemaakt. De verklaring van eventuele verschillen in arbeidsmarktbestemming die zich beperkt tot het aspect vakrichting en opleidingsresultaat is onvolledig, omdat de mate van succes op de arbeidsmarkt ook kan afhangen van extra kwalificaties in de vorm van een voltooide vooropleiding en een aantal individuele achtergrondkenmerken van de schoolverlaters.

In dit hoofdstuk worden de onderzochte EAO-schoolverlaters achtereenvolgens beschreven aan de hand van een aantal achtergrondkenmerken. Het gaat hierbij om een drietal persoonsgerelateerde kenmerken en een aantal kenmerken van de EAQ-opleiding en Yan fe Yonrnn|fiding

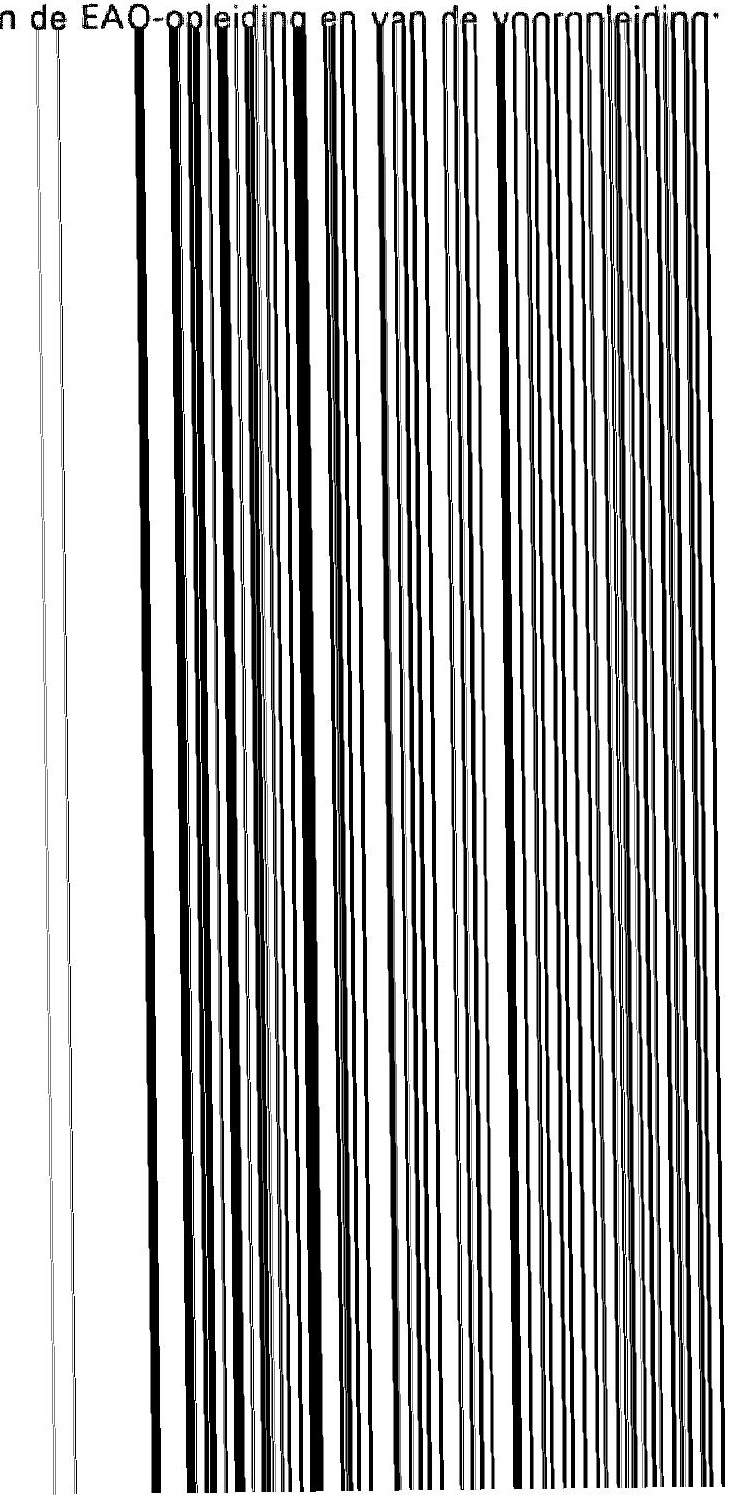




\section{PERSOONSKENMERKEN EN GENOTEN OPLEIDING}

\subsection{Inleiding}

De aan de EAO-school gevolgde vakrichting alsmede het resultaat waarmee men deze opleiding heeft verlaten, vormt de eerste invalshoek van waaruit de arbeidsmarktbestemming inzichtelijk kan worden gemaakt. De verklaring van eventuele verschillen in arbeidsmarktbestemming die zich beperkt tot het aspect vakrichting en opleidingsresultaat is onvolledig, omdat de mate van succes op de arbeidsmarkt ook kan afhangen van extra kwalificaties in de vorm van een voltooide vooropleiding en een aantal individuele achtergrondkenmerken van de schoolverlaters.

In dit hoofdstuk worden de onderzochte EAO-schoolverlaters achtereenvolgens beschreven aan de hand van een aantal achtergrondkenmerken. Het gaat hierbij om een drietal persoonsgerelateerde kenmerken en een aantal kenmerken van de EAQ-opleiding en Yan fe Yonrnn|fiding

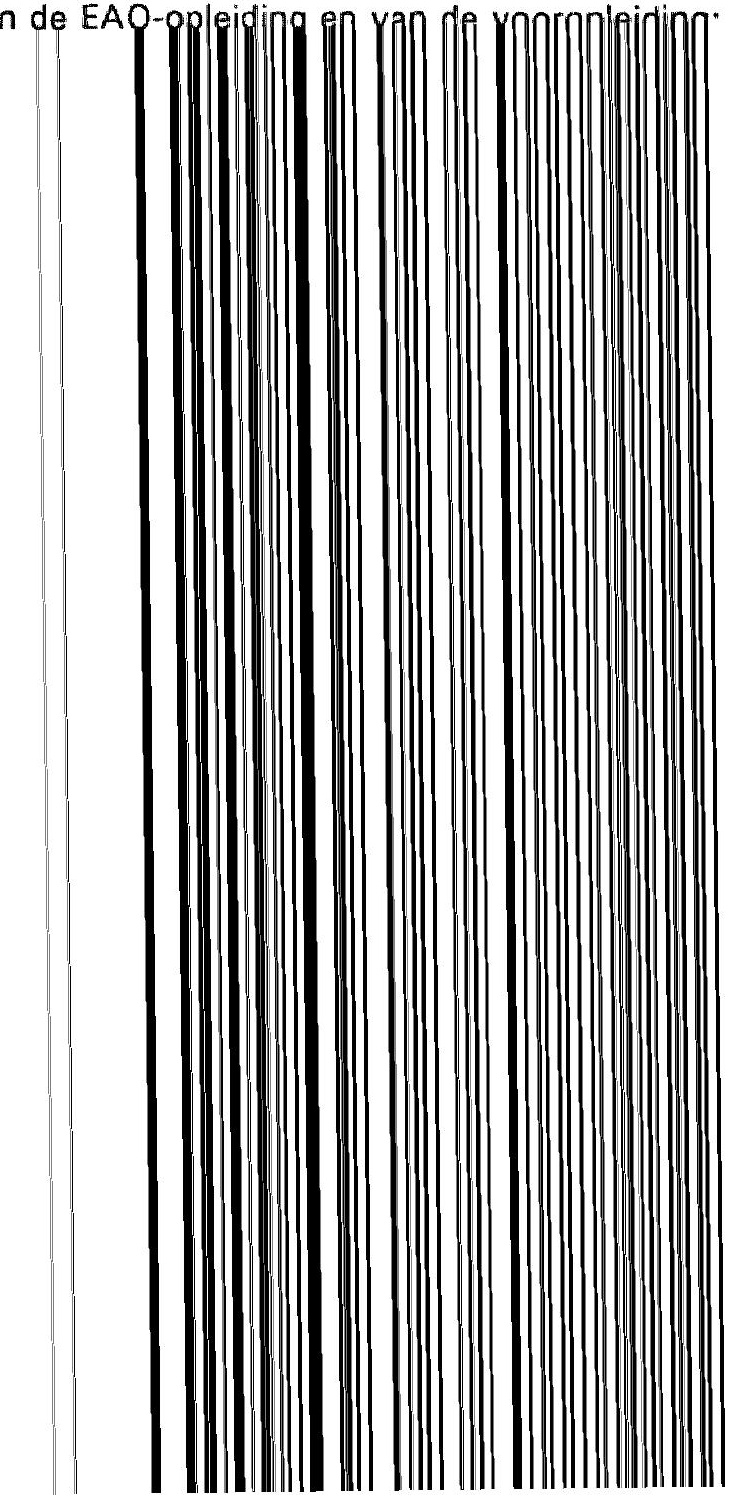




\section{PERSOONSKENMERKEN EN GENOTEN OPLEIDING}

\subsection{Inleiding}

De aan de EAO-school gevolgde vakrichting alsmede het resultaat waarmee men deze opleiding heeft verlaten, vormt de eerste invalshoek van waaruit de arbeidsmarktbestemming inzichtelijk kan worden gemaakt. De verklaring van eventuele verschillen in arbeidsmarktbestemming die zich beperkt tot het aspect vakrichting en opleidingsresultaat is onvolledig, omdat de mate van succes op de arbeidsmarkt ook kan afhangen van extra kwalificaties in de vorm van een voltooide vooropleiding en een aantal individuele achtergrondkenmerken van de schoolverlaters.

In dit hoofdstuk worden de onderzochte EAO-schoolverlaters achtereenvolgens beschreven aan de hand van een aantal achtergrondkenmerken. Het gaat hierbij om een drietal persoonsgerelateerde kenmerken en een aantal kenmerken van de EAQ-opleiding en Yan fe Yonrnn|fiding

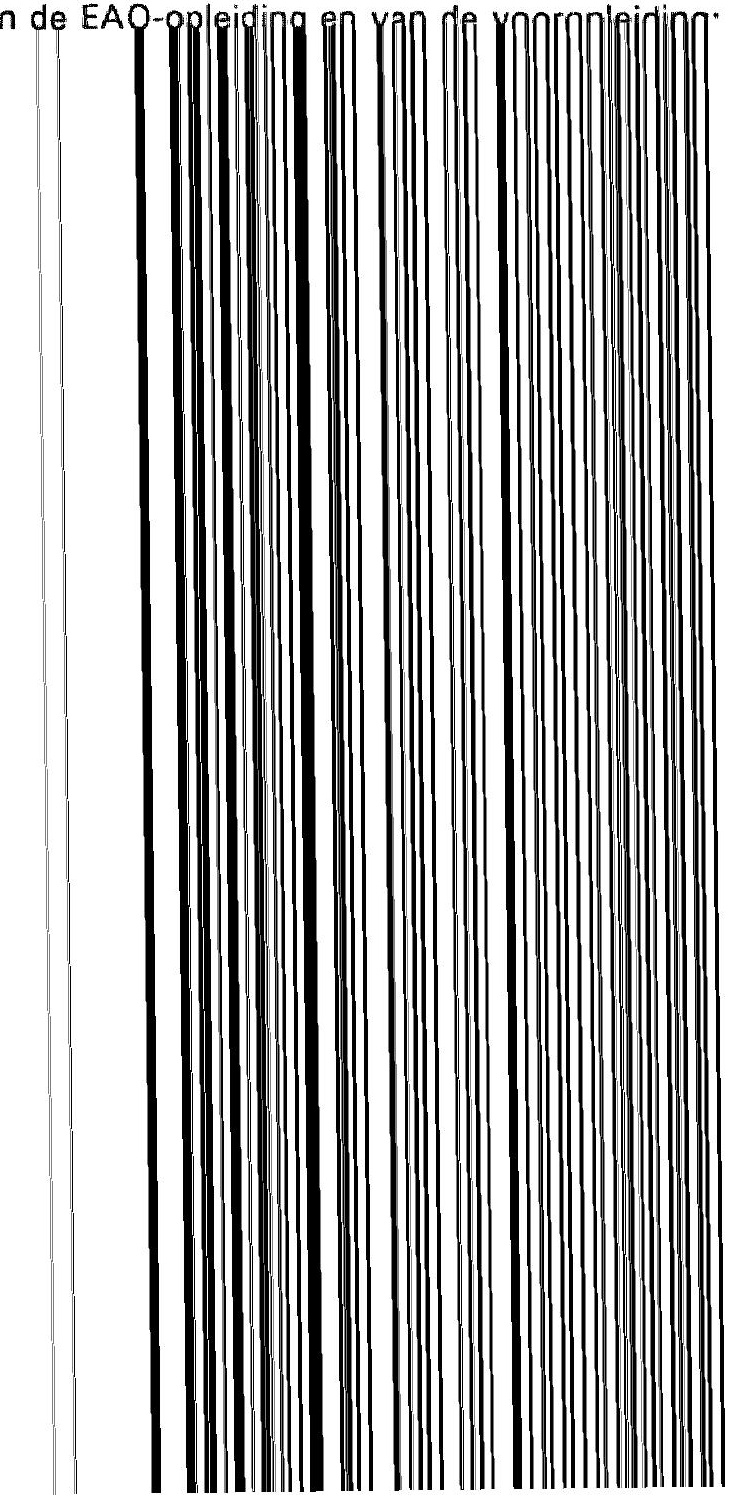




\section{PERSOONSKENMERKEN EN GENOTEN OPLEIDING}

\subsection{Inleiding}

De aan de EAO-school gevolgde vakrichting alsmede het resultaat waarmee men deze opleiding heeft verlaten, vormt de eerste invalshoek van waaruit de arbeidsmarktbestemming inzichtelijk kan worden gemaakt. De verklaring van eventuele verschillen in arbeidsmarktbestemming die zich beperkt tot het aspect vakrichting en opleidingsresultaat is onvolledig, omdat de mate van succes op de arbeidsmarkt ook kan afhangen van extra kwalificaties in de vorm van een voltooide vooropleiding en een aantal individuele achtergrondkenmerken van de schoolverlaters.

In dit hoofdstuk worden de onderzochte EAO-schoolverlaters achtereenvolgens beschreven aan de hand van een aantal achtergrondkenmerken. Het gaat hierbij om een drietal persoonsgerelateerde kenmerken en een aantal kenmerken van de EAQ-opleiding en Yan fe Yonrnn|fiding

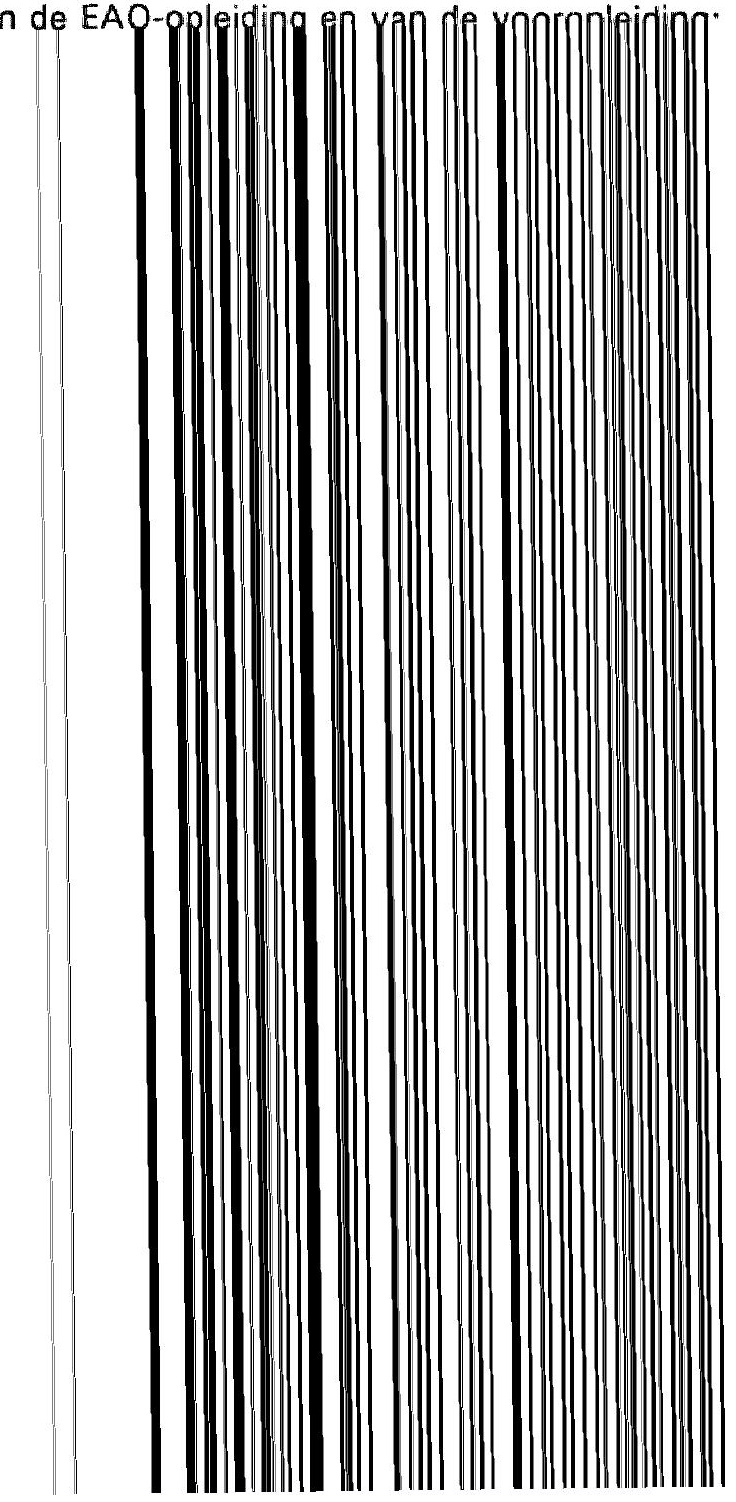




\section{PERSOONSKENMERKEN EN GENOTEN OPLEIDING}

\subsection{Inleiding}

De aan de EAO-school gevolgde vakrichting alsmede het resultaat waarmee men deze opleiding heeft verlaten, vormt de eerste invalshoek van waaruit de arbeidsmarktbestemming inzichtelijk kan worden gemaakt. De verklaring van eventuele verschillen in arbeidsmarktbestemming die zich beperkt tot het aspect vakrichting en opleidingsresultaat is onvolledig, omdat de mate van succes op de arbeidsmarkt ook kan afhangen van extra kwalificaties in de vorm van een voltooide vooropleiding en een aantal individuele achtergrondkenmerken van de schoolverlaters.

In dit hoofdstuk worden de onderzochte EAO-schoolverlaters achtereenvolgens beschreven aan de hand van een aantal achtergrondkenmerken. Het gaat hierbij om een drietal persoonsgerelateerde kenmerken en een aantal kenmerken van de EAQ-opleiding en Yan fe Yonrnn|fiding

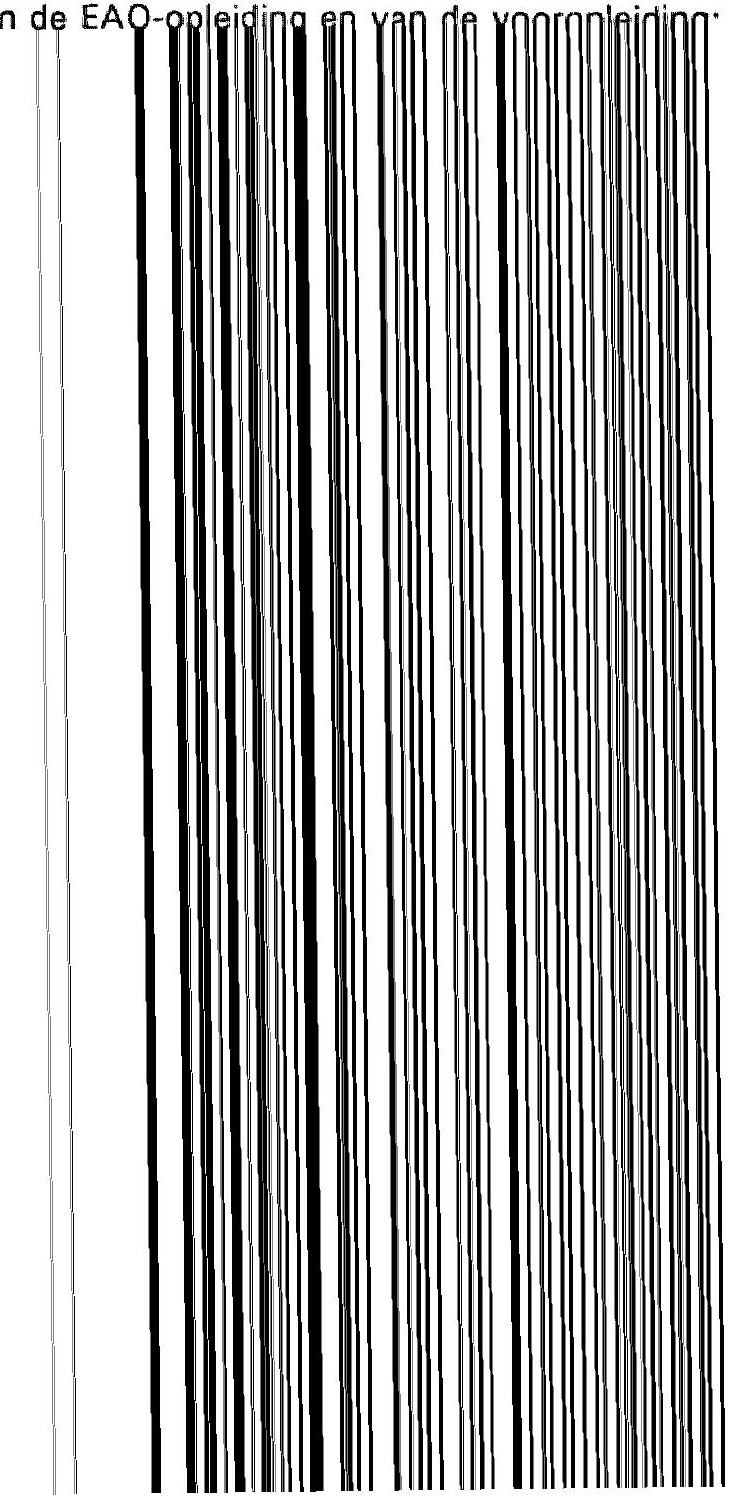




\section{PERSOONSKENMERKEN EN GENOTEN OPLEIDING}

\subsection{Inleiding}

De aan de EAO-school gevolgde vakrichting alsmede het resultaat waarmee men deze opleiding heeft verlaten, vormt de eerste invalshoek van waaruit de arbeidsmarktbestemming inzichtelijk kan worden gemaakt. De verklaring van eventuele verschillen in arbeidsmarktbestemming die zich beperkt tot het aspect vakrichting en opleidingsresultaat is onvolledig, omdat de mate van succes op de arbeidsmarkt ook kan afhangen van extra kwalificaties in de vorm van een voltooide vooropleiding en een aantal individuele achtergrondkenmerken van de schoolverlaters.

In dit hoofdstuk worden de onderzochte EAO-schoolverlaters achtereenvolgens beschreven aan de hand van een aantal achtergrondkenmerken. Het gaat hierbij om een drietal persoonsgerelateerde kenmerken en een aantal kenmerken van de EAQ-opleiding en Yan fe Yonrnn|fiding

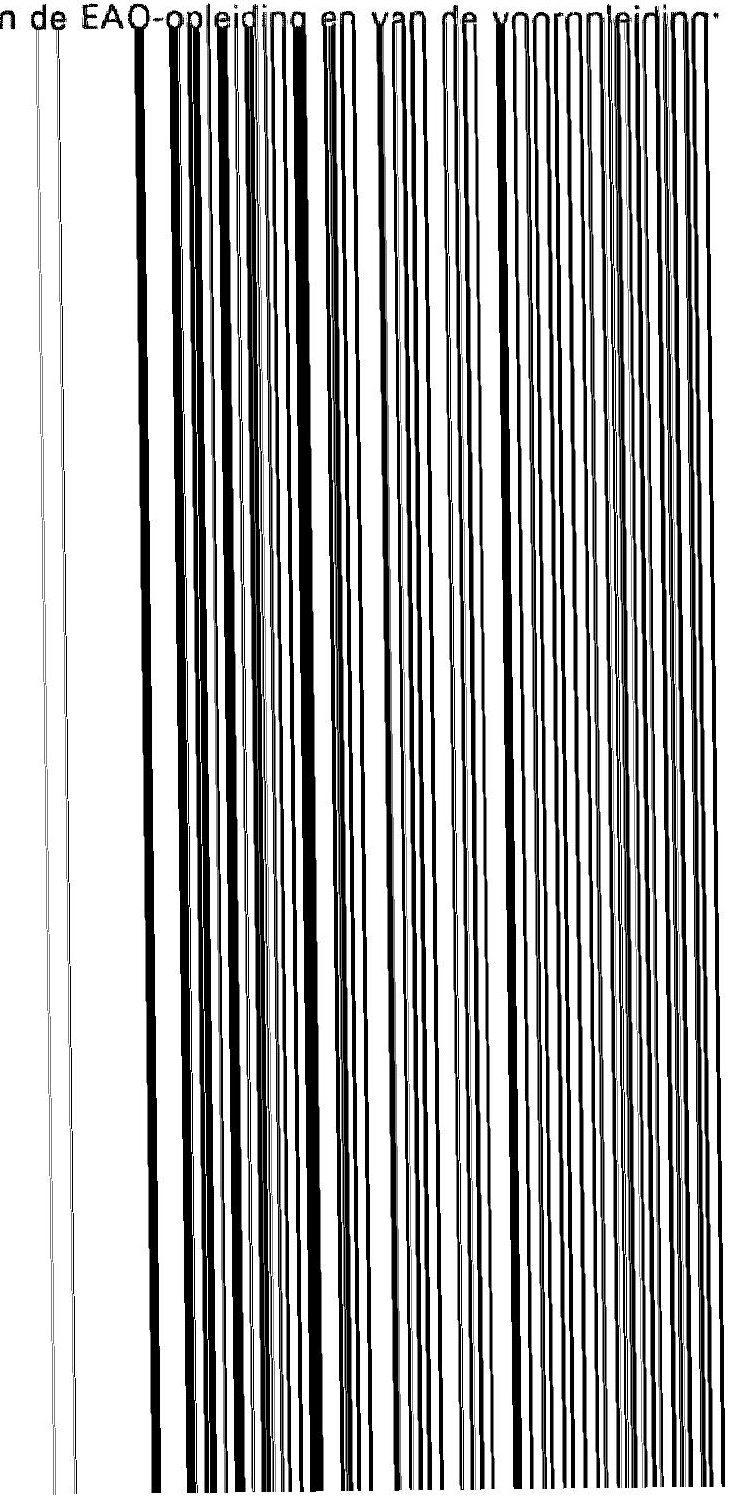




\section{PERSOONSKENMERKEN EN GENOTEN OPLEIDING}

\subsection{Inleiding}

De aan de EAO-school gevolgde vakrichting alsmede het resultaat waarmee men deze opleiding heeft verlaten, vormt de eerste invalshoek van waaruit de arbeidsmarktbestemming inzichtelijk kan worden gemaakt. De verklaring van eventuele verschillen in arbeidsmarktbestemming die zich beperkt tot het aspect vakrichting en opleidingsresultaat is onvolledig, omdat de mate van succes op de arbeidsmarkt ook kan afhangen van extra kwalificaties in de vorm van een voltooide vooropleiding en een aantal individuele achtergrondkenmerken van de schoolverlaters.

In dit hoofdstuk worden de onderzochte EAO-schoolverlaters achtereenvolgens beschreven aan de hand van een aantal achtergrondkenmerken. Het gaat hierbij om een drietal persoonsgerelateerde kenmerken en een aantal kenmerken van de EAQ-opleiding en Yan fe Yonrnn|fiding

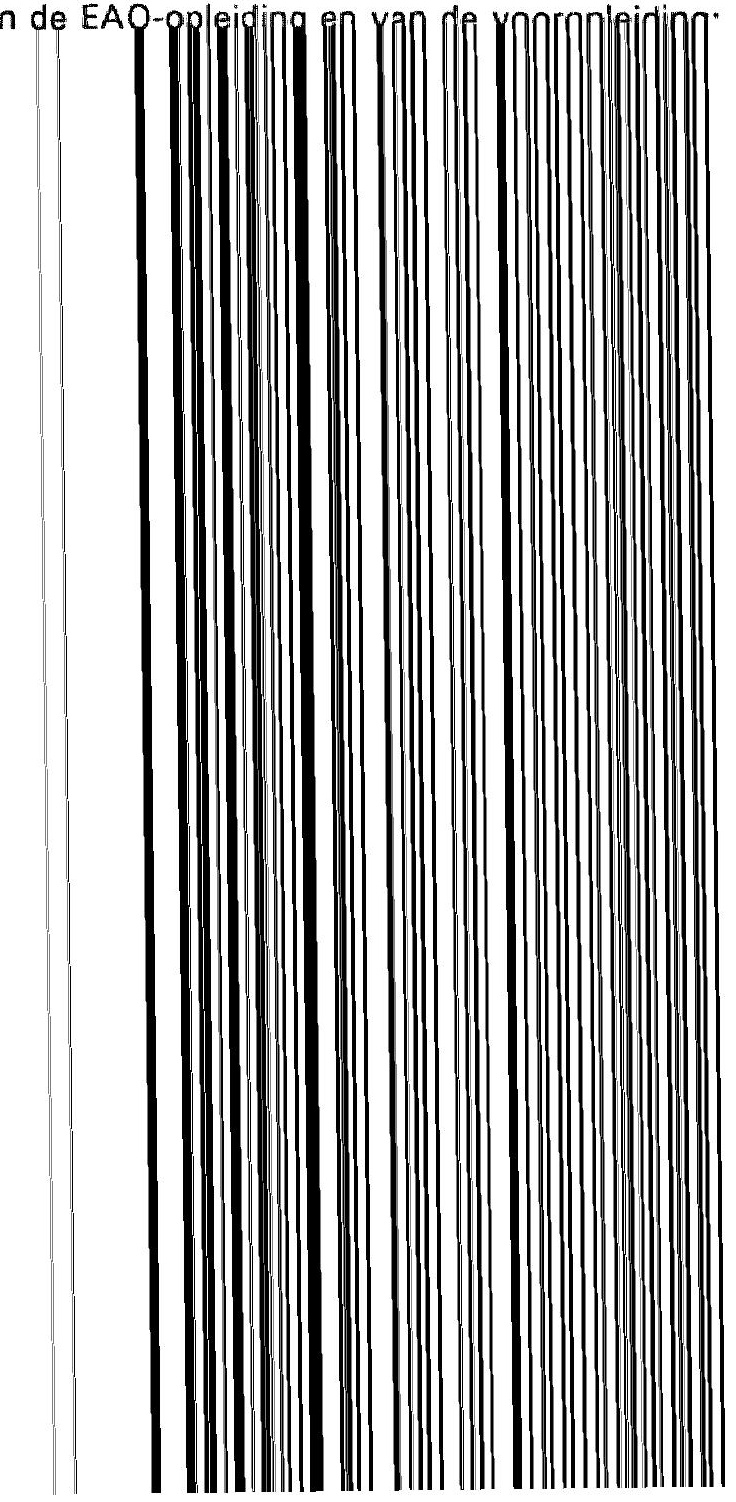




\section{PERSOONSKENMERKEN EN GENOTEN OPLEIDING}

\subsection{Inleiding}

De aan de EAO-school gevolgde vakrichting alsmede het resultaat waarmee men deze opleiding heeft verlaten, vormt de eerste invalshoek van waaruit de arbeidsmarktbestemming inzichtelijk kan worden gemaakt. De verklaring van eventuele verschillen in arbeidsmarktbestemming die zich beperkt tot het aspect vakrichting en opleidingsresultaat is onvolledig, omdat de mate van succes op de arbeidsmarkt ook kan afhangen van extra kwalificaties in de vorm van een voltooide vooropleiding en een aantal individuele achtergrondkenmerken van de schoolverlaters.

In dit hoofdstuk worden de onderzochte EAO-schoolverlaters achtereenvolgens beschreven aan de hand van een aantal achtergrondkenmerken. Het gaat hierbij om een drietal persoonsgerelateerde kenmerken en een aantal kenmerken van de EAQ-opleiding en Yan fe Yonrnn|fiding

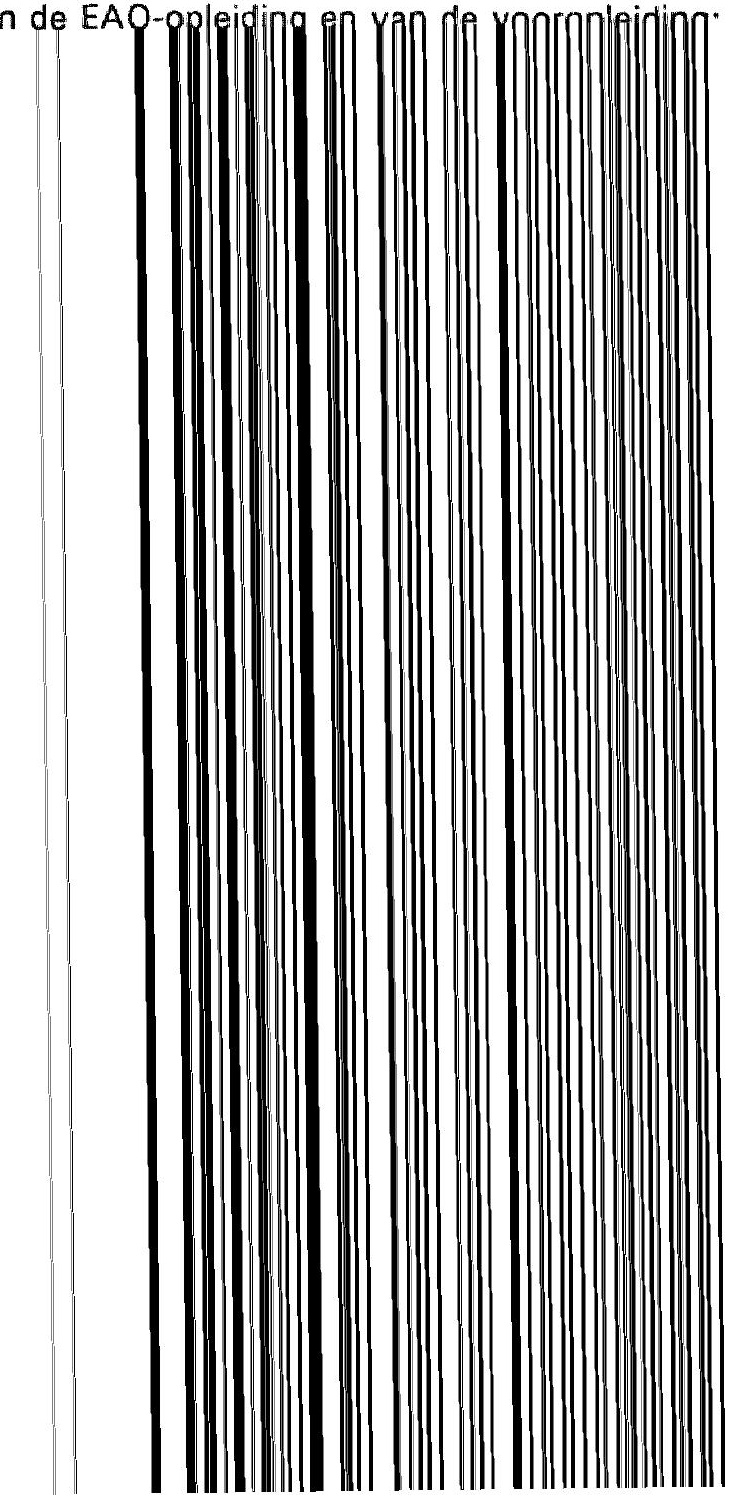




\section{PERSOONSKENMERKEN EN GENOTEN OPLEIDING}

\subsection{Inleiding}

De aan de EAO-school gevolgde vakrichting alsmede het resultaat waarmee men deze opleiding heeft verlaten, vormt de eerste invalshoek van waaruit de arbeidsmarktbestemming inzichtelijk kan worden gemaakt. De verklaring van eventuele verschillen in arbeidsmarktbestemming die zich beperkt tot het aspect vakrichting en opleidingsresultaat is onvolledig, omdat de mate van succes op de arbeidsmarkt ook kan afhangen van extra kwalificaties in de vorm van een voltooide vooropleiding en een aantal individuele achtergrondkenmerken van de schoolverlaters.

In dit hoofdstuk worden de onderzochte EAO-schoolverlaters achtereenvolgens beschreven aan de hand van een aantal achtergrondkenmerken. Het gaat hierbij om een drietal persoonsgerelateerde kenmerken en een aantal kenmerken van de EAQ-opleiding en Yan fe Yonrnn|fiding

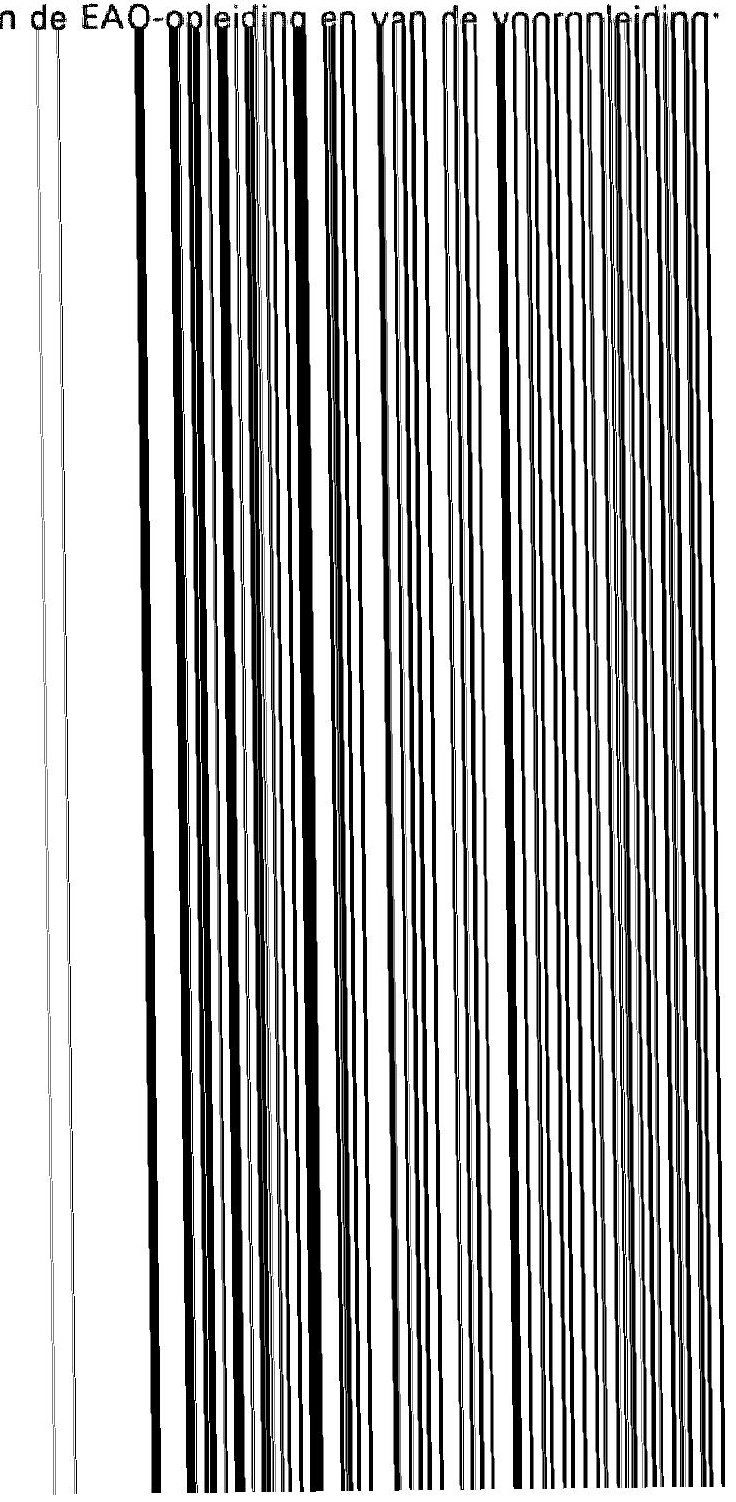




\section{PERSOONSKENMERKEN EN GENOTEN OPLEIDING}

\subsection{Inleiding}

De aan de EAO-school gevolgde vakrichting alsmede het resultaat waarmee men deze opleiding heeft verlaten, vormt de eerste invalshoek van waaruit de arbeidsmarktbestemming inzichtelijk kan worden gemaakt. De verklaring van eventuele verschillen in arbeidsmarktbestemming die zich beperkt tot het aspect vakrichting en opleidingsresultaat is onvolledig, omdat de mate van succes op de arbeidsmarkt ook kan afhangen van extra kwalificaties in de vorm van een voltooide vooropleiding en een aantal individuele achtergrondkenmerken van de schoolverlaters.

In dit hoofdstuk worden de onderzochte EAO-schoolverlaters achtereenvolgens beschreven aan de hand van een aantal achtergrondkenmerken. Het gaat hierbij om een drietal persoonsgerelateerde kenmerken en een aantal kenmerken van de EAQ-opleiding en Yan fe Yonrnn|fiding

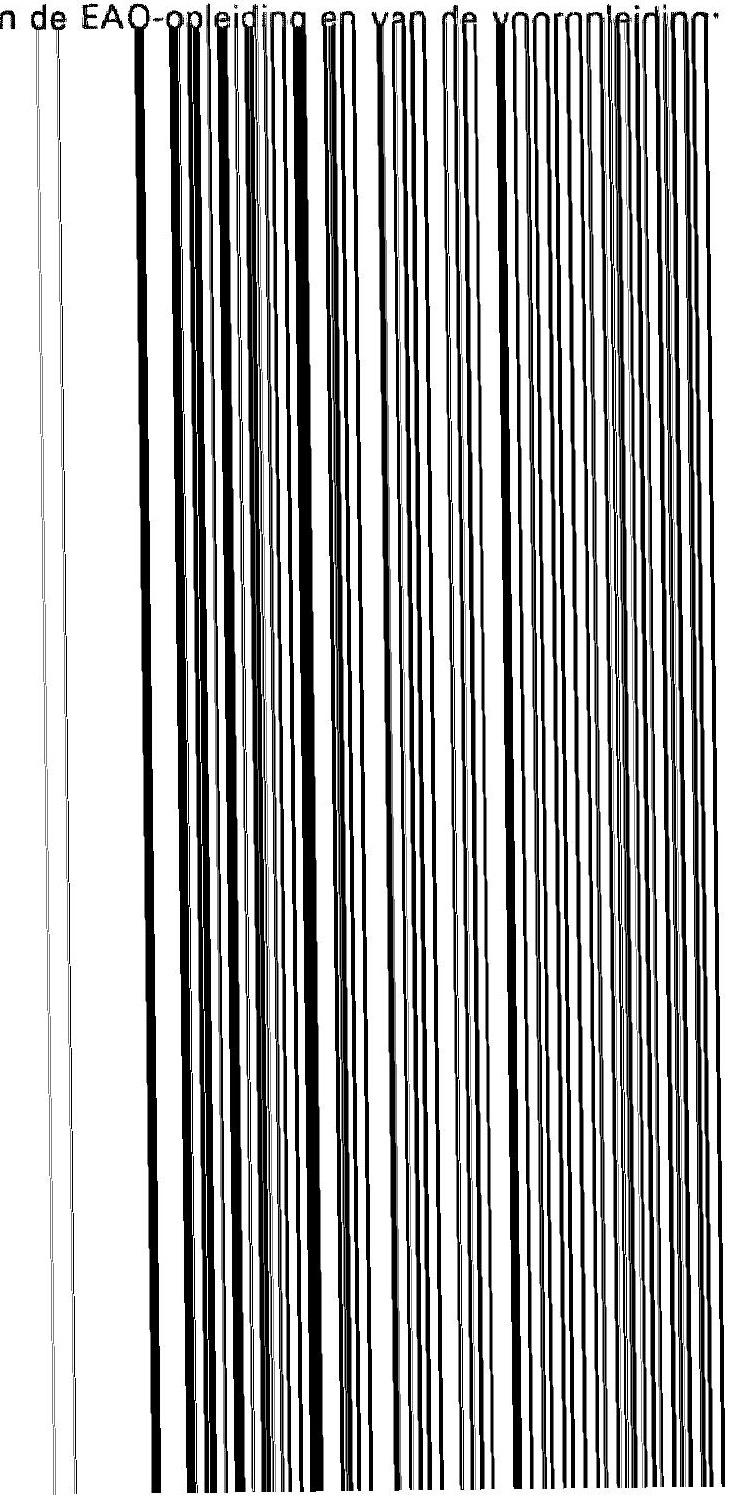

